\title{
Megaspore assemblages from the Jurassic and lowermost Cretaceous of Bornholm, Denmark
}

BY

EVA B. KOPPELHUS \& DAVID J. BATTEN
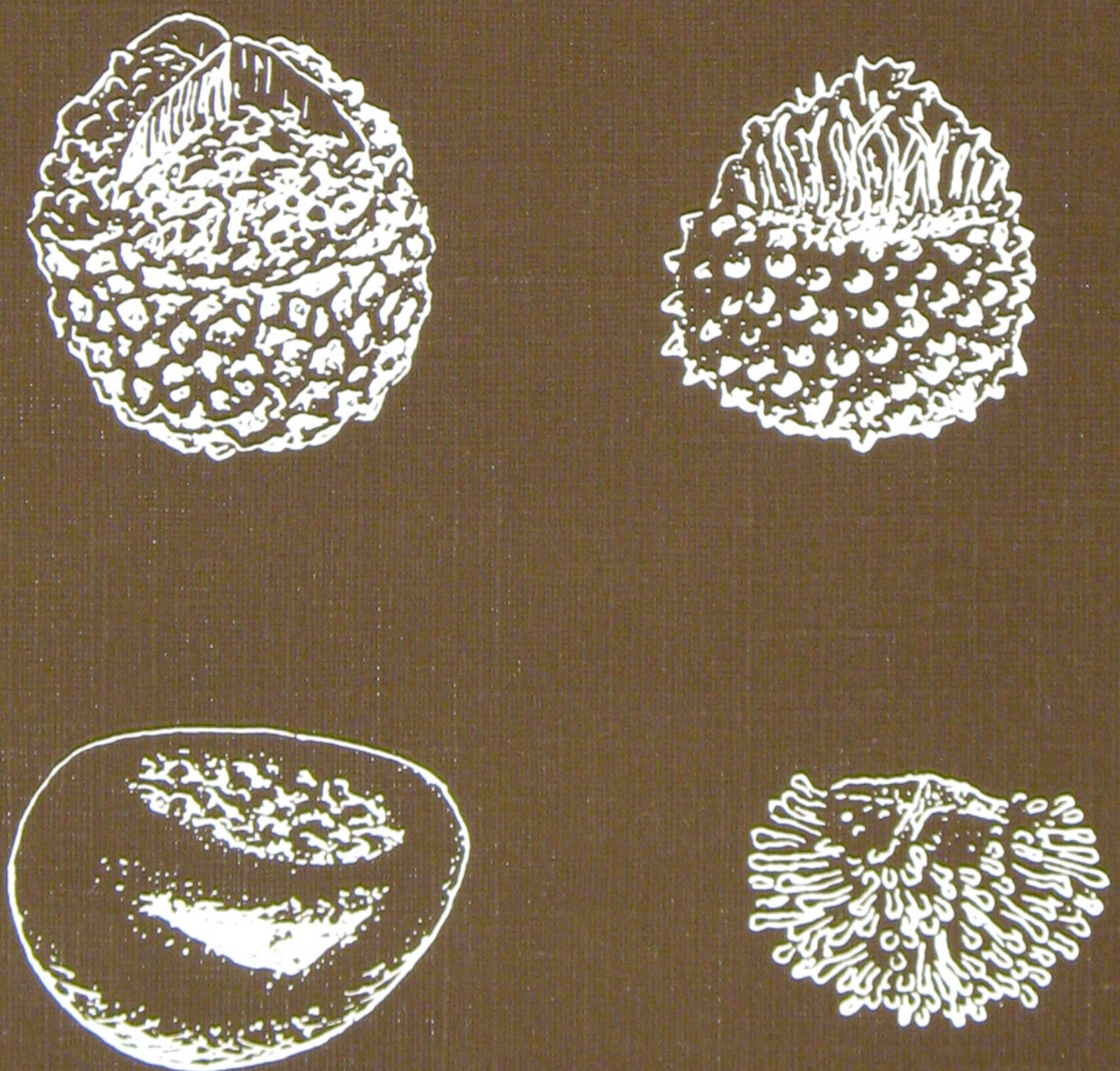


\section{Megaspore assemblages from the Jurassic and lowermost Cretaceous of Bornholm, Denmark}

BY

EVA B. KOPPELHUS \& DAVID J. BATTEN 
Key words:

Megaspores, Jurassic, Lower Cretaceous, morphology, biostratigraphy, Bornholm,

Denmark, Scandinavia

With 21 plates

Vignette:

Facsimile of figures 6.8, 6.1, 6.7, and 6.9 in Helge Gry's (1969) paper

on Jurassic megaspores from Bornholm

DGU Serie A nr. 32

ISBN 87-88640-82-5

ISSN $0901-0270$

Oplag: 1000

Tryk: AiO Tryk as, Odense

Tegning: Annabeth Andersen

Dato: 15.12 .1992

Eva Bundgaard Koppelhus, Geological Survey of Denmark,

Thoravej 8, DK-2400 København NV, Denmark

David John Batten, Institute of Earth Studies,

University of Wales, Aberystwyth, Dyfed SY23 3DB, UK

Redaktion: Leif Banke Rasmussen

(C) Danmarks Geologiske Undersøgelse,

Thoravej 8. DK-2400 København NV 


\section{Helge Gry}

This paper is dedicated to the late Dr. Helge Gry who, until a few years before his death in 1982, worked for the Geological Survey of Denmark in Copenhagen. He particularly enjoyed carrying out field work on Bornholm where he spent much time attempting to unravel the geological history of this tectonically complex area. 


\section{Contents}

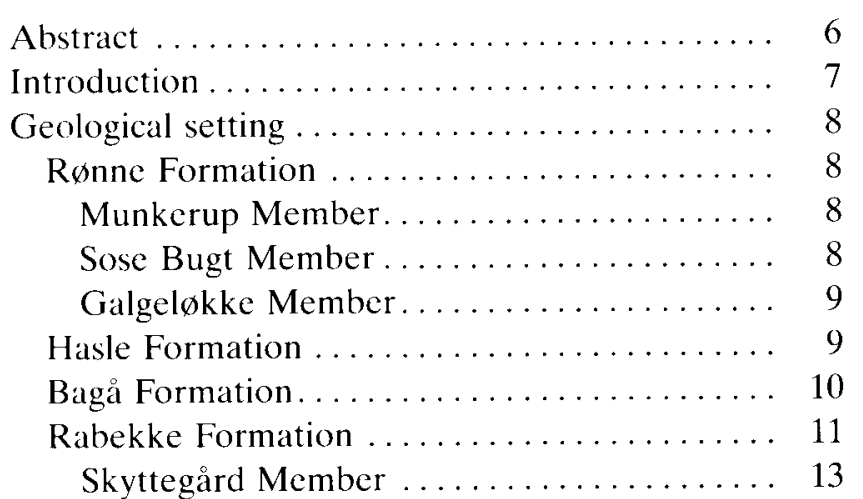

Robbedale Formation ...................14

Material and methods .................. 15

Systematic palynology ................. 17

Introduction ......................... 17

Systematics........................ 17

Affinities......................... 30

Stratigraphic value $\ldots \ldots \ldots \ldots \ldots \ldots \ldots \ldots . \ldots . \ldots . \ldots$

Acknowledgments.................... 33

References .......................... 34

Appendix ......................... 37

Plates $1-21 \ldots \ldots \ldots \ldots \ldots \ldots \ldots \ldots . . . \ldots 39$ 


\section{Abstract}

There are more than 600 slides containing megaspores in "Helge Gry's collection", housed at the Geological Survey of Denmark in Copenhagen. The majority of the specimens are unnamed, all are from the Danish island of Bornholm in the Baltic Sea, and none has been described hitherto. The stratigraphic distribution of 22 of the taxa was, however, taken into account in a paper by Gry, published in 1969, and 16 of these were illustrated by small line drawings. He considered the lithology, areal extent and depositional history of what were thought at the time to be only Jurassic strata on Bornholm. The youngest part of the succession he discussed, the "Purbeck beds" (Rabekke and Robbedale Formations), are, however, now known to be mainly, if not entirely, of earliest Cretaceous age.

In the present paper Gry's megaspore records are brought up to date so that they can be used more effectively along with other microfossils in drawing biostratigraphical and palaeoenvironmental conclusions. All 22 taxa to which he referred are discussed and illustrated, mostly with scanning electron micrographs, and their nomenclature emended where necessary. Descriptions and figures of an additional 15 forms encountered in the collection are included. Three of these are new species of megaspores and one is a palynomorph of uncertain origin, named Henrisporites bornholmensis, Paxillitriletes kristinae, $P$. rasmusii and Aneuletes discus respectively.

Most, if not all, of the megaspores in Gry's collection are likely to have selaginellalean or isoetalean affinities. There is no evidence of the presence of heterosporous water ferns. The assemblages differ significantly in composition according to their relative ages, with several forms being of considerable biostratigraphic value. There is, however, still room for greater precision in determining local stratigraphic ranges, and also a need to apply occurrence data to palaeoenvironmental interpretations. This will require carefully documented collecting of new samples. 


\section{Introduction}

More than 20 years ago Helge Gry (1969) gave an account of the lithology, areal extent, depositional history and megaspore content of Mesozoic deposits of the Danish island of Bornholm in the Baltic Sea (figs 1, 2). Emphasis was placed on the Lower and Middle Jurassic sections. The younger "Purbeck beds" were only briefly considered. At that time they were also thought to be Jurassic but are now considered to be largely if not entirely earliest Cretaceous, Berriasian (Gravesen et al., 1982). Discussion of the megaspores recovered from the deposits within several fault blocks on the southern and western parts of the island was restricted mainly to notes on the occurrence of previously described species and their stratigraphic significance. Of the 22 taxa recorded, 16 were illustrated by small line drawings.

Although the megaspores in Gry's paper have provided a useful basis for dating most of the members of the several Jurassic and earliest Cretaceous formations on Bornholm (Gravesen et al., 1982), the lack of descriptions and photographic illustrations of most of the taxa has rendered comparison with other mid-Mesozoic assemblages difficult. Only three species have been studied in some detail hitherto (Kempf, 1972). These are Margaritatisporites turbanaeformis (referred to Trileites candoris herein), Horstisporites kendallii and $I s$ tisporites murrayi (Trileites murrayi herein), specimens of which were thin sectioned and examined under a transmission electron microscope (TEM). Gry did not provide the samples from which they were isolated. They had, instead, been collected from unspecified levels in the Hasle Klinkerfabrik clay pit (fig. 3) by two of Kempf's colleagues four years previously and were regarded as "Dogger in age" (Kempf, 1972, p. 152).

The main purpose of our paper is to bring Gry's work up to date so that its value can be better appreciated by others who attempt to use plant microfossils for resolving biostratigraphic problems and contributing to palaeoenvironmental interpretations within the Mesozoic. We describe and illustrate all of the species to which he referred, where necessary changing the nomenclature to bring it into line with current use. We also treat in a similar way other species in his slides which he did not mention so that our review of his megaspore collection is more comprehensive. The systematic descriptions are followed by a discussion of the botanical affinities of the plants represented, and of the biostratigraphic value and potential of the spores. 


\section{Geological setting}

The exposed Mesozoic deposits of Bornholm range in age from Late Triassic to Late Cretaceous. Throughout their geographic extent the oldest beds unconformably overlie Lower Palaeozoic sedimentary rocks and Precambrian crystalline basement within a series of fault blocks situated at the southern end of the Fennoscandian Border Zone (Gravesen et al., 1982 and references cited therein). Outcrops are mainly restricted to low cliffs along the southern and western coasts (fig. 2). Inland exposures are limited to a few quarries, many of which are now disused, and as a result at least partly degraded by weathering and covered with vegetation. This applies particularly to the Jurassic and lowermost Cretaceous localities, the only good quarry exposure being of the Lower to Middle Jurassic Baga Formation at its type locality, the Hasle Klinkerfabrik clay pit (fig. 3).

Much of the stratigraphic knowledge of the TriassicLower Cretaccous succession is attributable to the work of Gry $(1956,1960,1968,1969)$ but the nomenclature he used was mainly informal and applicable only locally within individual fault blocks. This approach is a reflection of the fact that most of the sediments accumulated in paralic environments. The facies change rapidly both vertically and laterally, and marine fossils are generally absent. Stratigraphic subdivision and correlation of sections throughout the area of outcrop was, however, hampered by Gry's descriptive, block-by-block approach but Gravesen et al. (1982) presented a new lithostratigraphic subdivision of the succession comprising two groups, three formations and ten members. Of these, only the Triassic Risebæk Member of the Kågeröd Formation and the Cretaceous Tornhøj and Rødbjerg Members of the Jydegård Formation are not considered further here. As shown on figure 4 , significant periods of time are not, or may not be, represented in the Jurassic-Lower Cretaceous sedimentary succession. There are unconformities between the Bagå and Rabekke Formations, and perhaps also between the Hasle and Bagå Formations (see below). This is in contrast to the succession that has been interpreted, from shallow seismic investigations, to be present offshore in the eastern Rønne Graben, immediately to the west of Bornholm. Jensen \& Hamann (1989) suggested on the basis of their geophysical data that sedimentation was continuous throughout the Jurassic and into the earliest Cretaceous (represented by the Berriasian Rabekke Formation) in this region, but they had no biostratigraphic data to support their con- clusion. Both the Robbedale and Jydegărd Formations are apparently absent from the graben.

\section{Rønne Formation}

\section{Munkerup Member}

Gry (1969) recovered megaspores from beds within what are now known as the Munkerup and Sose Bugt Members of the Rønne Formation (fig. 4). The areal extent of the first of these is very limited, both at outcrop and in the subsurface (Gry, 1969, pp. 73-75, figs 2,3; Gravesen et al., 1982, p. 14, figs 2,6,10), and it may be no more than $20 \mathrm{~m}$ thick. The dominant lithology is grey to black clay. This commonly contains abundant particulate plant remains, occasionally forming coaly laminae one or two $\mathrm{cm}$ thick. Deposition in lacustrine conditions is indicated (Koppelhus, 1991). Harris (1937) recorded plants from it which he attributed to the Thaumatopteris flora of earliest Jurassic, Hettangian age. This dating has recently been confirmed on the basis of the composition of palynomorph assemblages recovered from the member by Koppelhus (1991) who referred them to the Pinuspollenites-Trachysporites Zone of Lund (1977).

\section{Sose Bugt Member}

Approximately $26 \mathrm{~m}$ of the Sose Bugt Member is well exposed in the cliff at the type locality of Sose Bugt on the south coast, although the lower boundary with the Munkerup Member is not seen; indeed it is quite possible that the older member is absent from the area. The maximum thickness of the Sose Bugt Member has been estimated to be about 40m (Gravesen et al., 1982, p. 17). It extends a short distance inland from Sose Bugt and is thought to be also exposed on the coast further west near Rønne (east of Ormebæk; Gry, 1969. p.77, fig. 4; Gravesen et al., 1982, pp. 17,18, figs 6,7). The upper boundary with the Hasle Formation is poorly exposed west of Sose Odde (Surlyk \& NoeNygaard, 1986).

Alternating beds of fine-grained, cross-laminated sand, often containing plant debris, and thin beds of grey laminated clay and interlaminated clays and silts dominate the succession. Concentrations of organic detritus forming thin coal seams, and rootlet-bearing paleosols are common (Arndorff, 1991). Some thick units of fine to medium-grained sand occur in the middle 
part, and trace fossils are abundant at some levels in the middle and upper parts of the section.

Deposition on a partly vegetated lower delta plain traversed by sandy water courses is suggested for the lower Sose Bugt Member. The presence of marine trace fossils and other sedimentary characteristics of the upper part of the member indicate transgressive conditions at this time. A recent sequence stratigraphic analysis of the Sose Bugt Member (Surlyk et al., in prep.) has revealed a number of key surfaces within the succession, some of which may be tentatively correlated with surfaces identified by Haq et al. (1988) in their sea-level cycle chart.

Gry (1969, fig. 7) dated the Sose Bugt section as Lias a. Koppelhus (1991) confirmed the age-range implied by this, i.e. Hettangian-early Sinemurian, on the basis of the miospores recovered. The assemblages from the lower part of the succession are similar to those from the Munkerup Member, hence placing it within the Pinuspollenites-Trachysporites Zone and dating it as Hettangian. The assemblages from the upper part contain fewer taxa. They correlate with the Cerebropollenites macroverrucosus Zone of Dybkjær (1991) which is thought to indicate a Sinemurian age.

\section{Galgeløkke Member}

The thickness of the Galgeløkke Member, which is known to be present only on the Rønne-Hasle Block (Gry, 1969, p. 77, fig. 4; Gravesen et al., 1982, pp. $18,19,22$, fig. 7), seems to be quite variable, but it is considerably greater than that of the Sose Bugt Member. Gry (1969) suggested a range of between 150 and $210 \mathrm{~m}$. Very light coloured fine-grained sands together with heterolithic wavy and flaser-laminated sand and clay dominate the very variable lithology of the member. Thin coal seams overlying rootlet horizons and accumulations of carbonised plant detritus occur locally but particulate organic matter is widely dispersed. On the other hand, megaspores have not so far been recovered from any of these deposits.

The boundary between the Sose Bugt and Galgelokke Members is approximately at the level of the horizons yielding the bivalve Cardinia follini Lundgren, which were interpreted by Gry $(1969$, p.77) to indicate a brackish-water incursion. The only other fossils to have been encountered are remains of the fossil plant Dictyophyllum, noted by Grönwall \& Milthers (1916), rare agglutinating foraminifers (Sellwood, 1972), locally abundant trace fossils (Rolle, 1978) and miospores (Koppelhus, 1991).

The lack of megaspores and other age-diagnostic ossils meant that Gry (1969) had to date the Galgelokke deposits solely on the basis of their stratigraphic position between the Sose Bugt and Hasle successions. Since the latter was determined to be of "Lias $\gamma$ age" (early Pliensbachian), the Galgeløkke Member was dated as Sinemurian. The miospore assemblages are similar in composition to those recovered from the upper part of the Sose Bugt Member, and all appear to correlate with the Cerebropollenites macroverrucosus Zone. There are fewer pollen grains in the Galgeløkke assemblages, and reworked Carboniferous spores seem to be more common than they are in the other two members (Koppelhus, 1991; Nielsen \& Koppelhus, 1991). It is possible that the Galgeløkke Member was deposited at the same time as the upper Sose Bugt Member but in a different environment (Koppelhus, 1991). The overall composition of the palynological assemblages is consistent with a Sinemurian age but it does not provide unequivocal evidence for such a determination.

The Galgeløkke Member is thought to comprise a generally regressive tidal flat complex of sands and muds followed by a major tidal channel sequence with sandstones of sand-wave origin capped by marsh deposits (Sellwood, 1972; Rolle, 1978; Gravesen et al., 1982). Tyge (1990) interpreted the sedimentary succession at the type locality to comprise deposits of a delta front mouth bar and associated intertidal flats. Megaspores have rarely been found in either modern or ancient cross-bedded channel, shoal, bar and tidal flat sands. As pointed out by Gravesen et al. (1982), the member may well have accumulated during a regressive phase within a period of otherwise general transgression which ultimately led to the deposition of the overlying, fully marine Hasle Formation (Surlyk \& Noe-Nygaard, 1986).

\section{Hasle Formation}

This consists of between 80 and 110m (Gry, 1969) of mainly moderately to well indurated coarse-grained siltstone and fine-grained limonitic sandstone (Gry, 1969). Gravels are present as thin laminae. Clay ironstones also occur. Hummocky cross-stratification is present in the siltstones and sandstones of the exposed part of the succession and is interpreted to reflect inner shelf deposition (Surlyk \& Noe-Nygaard, 1986). Referred to as "marine Lias $\gamma$ Beds" by Gry (1969), the formation has yielded an abundant marine invertebrate fauna (Gravesen et al., 1982, and references cited therein) which has dated it as early Pliensbachian ( $U p$ tonia jamesoni to Prodactylioceras davoei Zones). The lithologies of the formation at the type locality in low coastal cliffs to the south of Hasle and elsewhere are not suitable for the recovery of megaspores. They are also largely devoid of small spores and pollen grains; only a few, very impoverished assemblages have been recovered (Koppelhus, unpublished). 


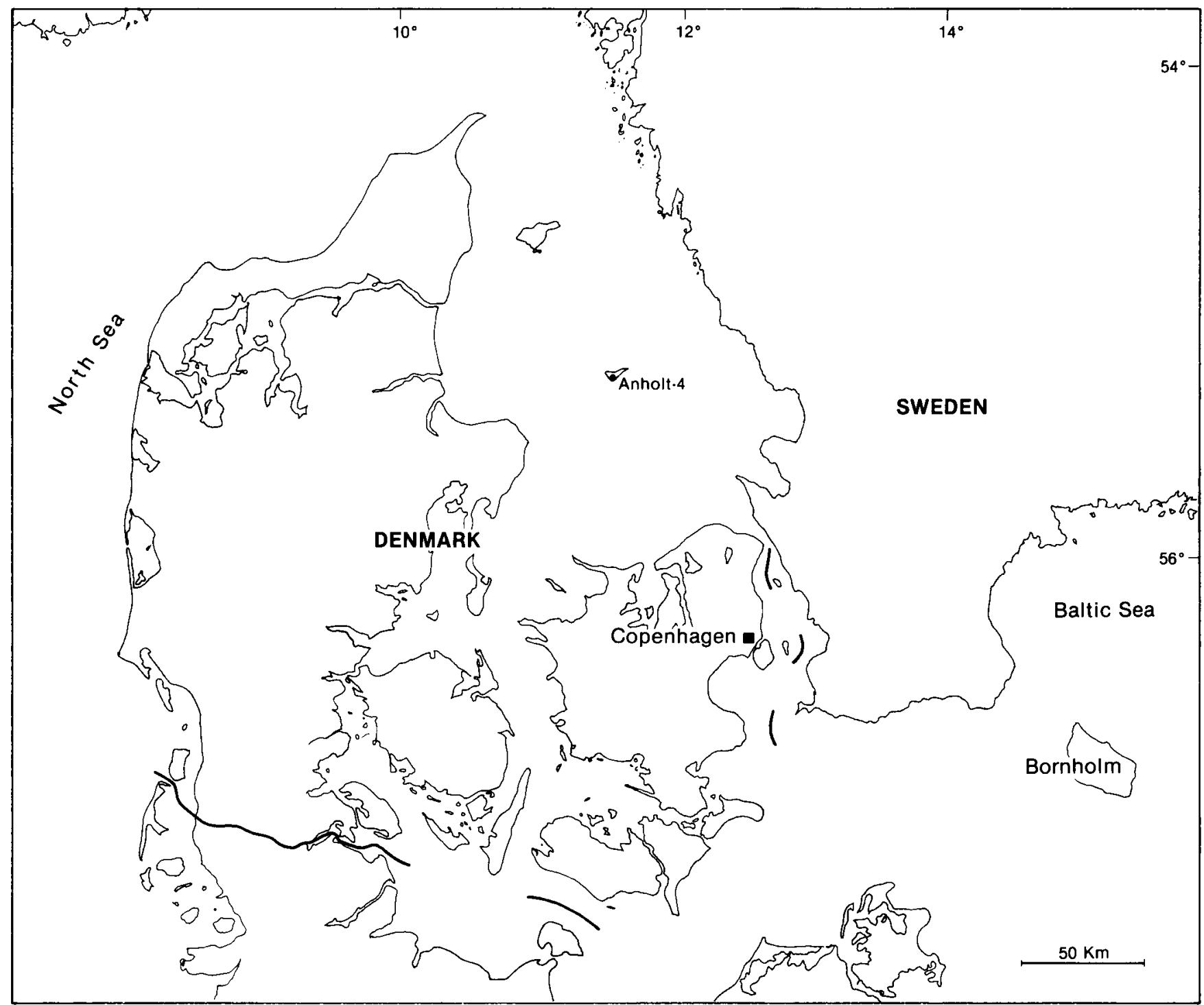

Fig. I. Map showing the location of Bornholm in the southern Baltic Sea and of the Anholt-4 borehole to which reference is made in the text.

\section{Bagå Formation}

The Bagå Formation may conformably overlie, or rest disconformably on the Hasle Formation within the confines of the Rønne-Hasle Block. According to Gry (1969) it lies unconformably on Silurian shales within the Boderne outlier (fig. 2). Most of its more than $270 \mathrm{~m}$ consists of sands, heteroliths, clays and coals typically in fining upwards cycles (Gry, 1960; Gravesen et al., 1982, pp. 26,27). At the type locality, the Hasle Klinkerfabrik clay pit (Gry, 1969, p. 80, fig. 5; Gravesen et al., 1982, fig. 20; Bagågraven clay pit in Hoelstad, 1985), the highest beds include conglomerates containing boulders of kaolinized granite (Gravesen et al., 1982, p. 27, fig. 25C,D).

Gry (1969, pp. 78-84) described the succession under the local names Levka, Sorthat, and Bagå beds. These were not precisely correlated because of tectonic complications and rapid vertical and lateral variations in facies. On the basis of the megaspores recovered, he considered the Levka and Sorthat beds to be roughly contemporaneous whereas he thought the Baga beds accumulated slightly later. He also placed the coalbearing deposits at Korsodde and Onsbæk, and the conglomerate-bearing succession at Boderne, in the Bagå series or beds. He dated the Bagå Formation as a whole as Bajocian-Bathonian. The palynomorphs recovered from it, however, suggest that the lower part is at least as old as latest Toarcian (Hoelstad, 1985) and may well be older (Koppelhus \& Nielsen, in prep.); hence the question marks through the "no stratigraphic record" interval between the Hasle and Bagå Formations on figure 4.

Any unconformable relationships between the base of the Baga Formation and the underlying Lower Jurassic or older rocks may reflect early Middle Jurassic erosion of late Pliensbachian and younger Early Jurassic deposits, as suggested by Gravesen et al. (1982). The fining upward units of the Bagå Formation were deposited in a complex of meandering channels, levées and backswamps, and brackish interdistributary bays (Gravesen et al., 1982). 


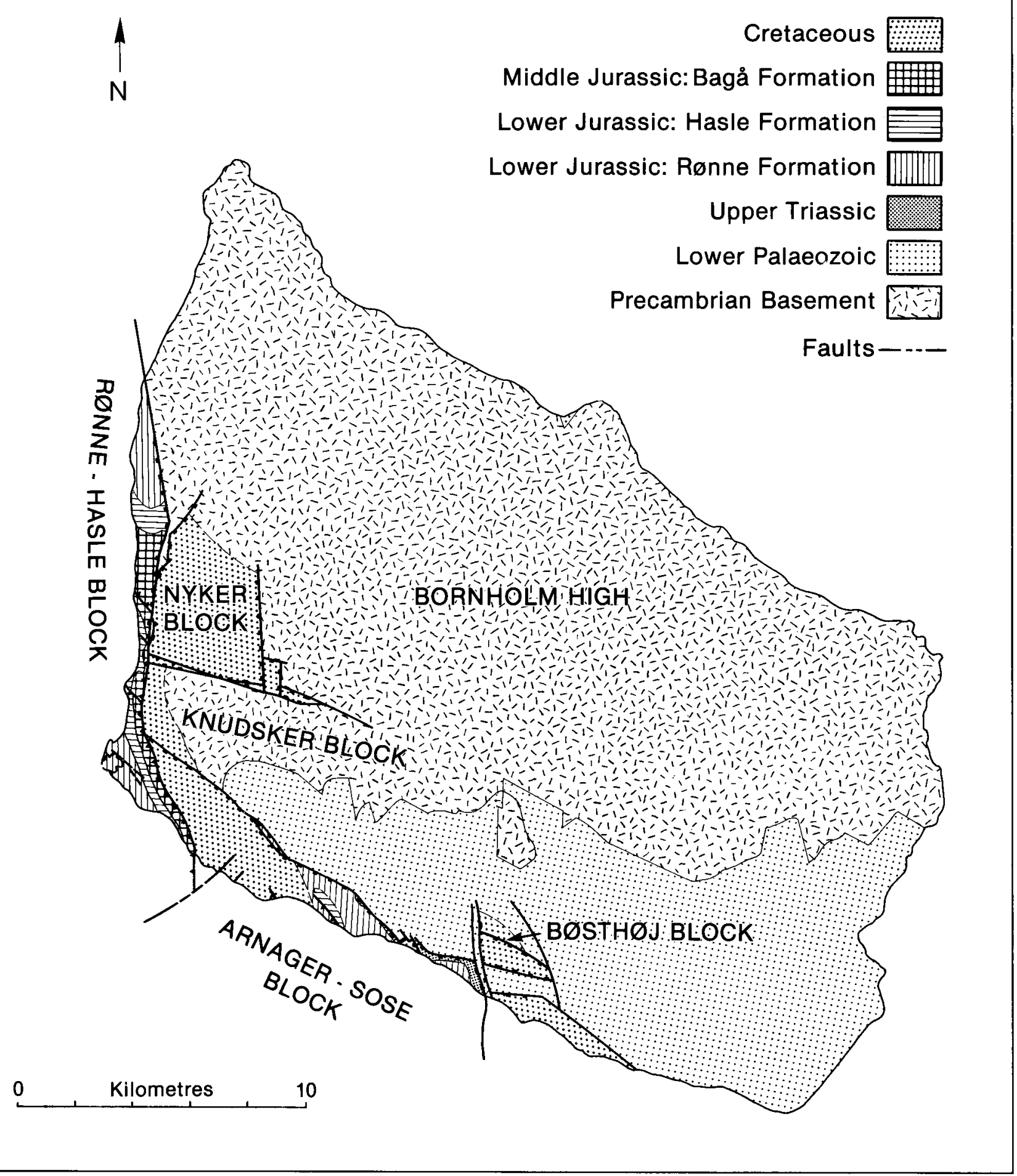

Fig. 2. Geological map of Bornholm, adapted from fig. 2 in Gravesen et al. (1982).

\section{Rabekke Formation}

The much younger Rabekke Formation of the Nyker Group overlies the Galgeløkke Member on the Arnager-Sose Block, and Palaeozoic or Precambrian kaolinized basement rocks on five other fault blocks (Gravesen et al., 1982, p. 28, figs 26,27). It consists of varying thicknesses of fluvial sandstone, sand and clay followed by supratidal-intertidal swamp clay, lignite and sand. These comprise the Homandshald and Skyttegård Members respectively, and are equivalent to the "basal sequence" and "lower clay sequence" of Gry (1956). At the type locality in Arnager Bugt, the former is between 20 and $30 \mathrm{~m}$ thick (Gry, 1956; Gravesen, 1982). The predominant medium- to coarse-grained and poorly sorted sands, sandstones and pebble beds are devoid of fossils apart from some rootlets and comminuted plant debris in the upper part of the member. 


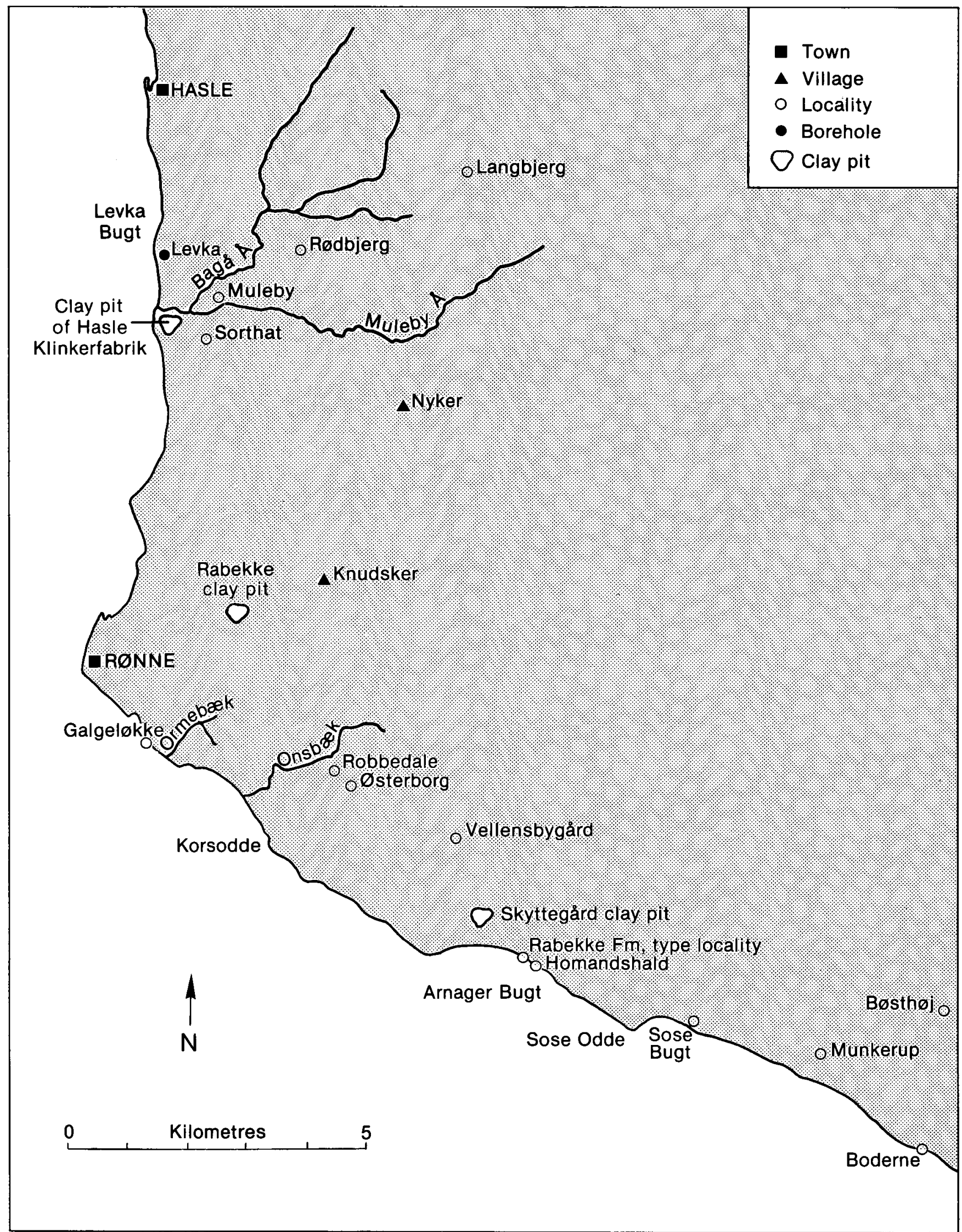

Fig. 3. Map showing coastline of part of southern and western Bornholm and location of all places on the island mentioned in the text apart from Sosevig. This is an alternative name for Sose Bugt. Gry (1969) referred to Vellengsby and Vellengsbygård whereas the spelling of the latter on the currently available topographic map is Vellensbygärd. 


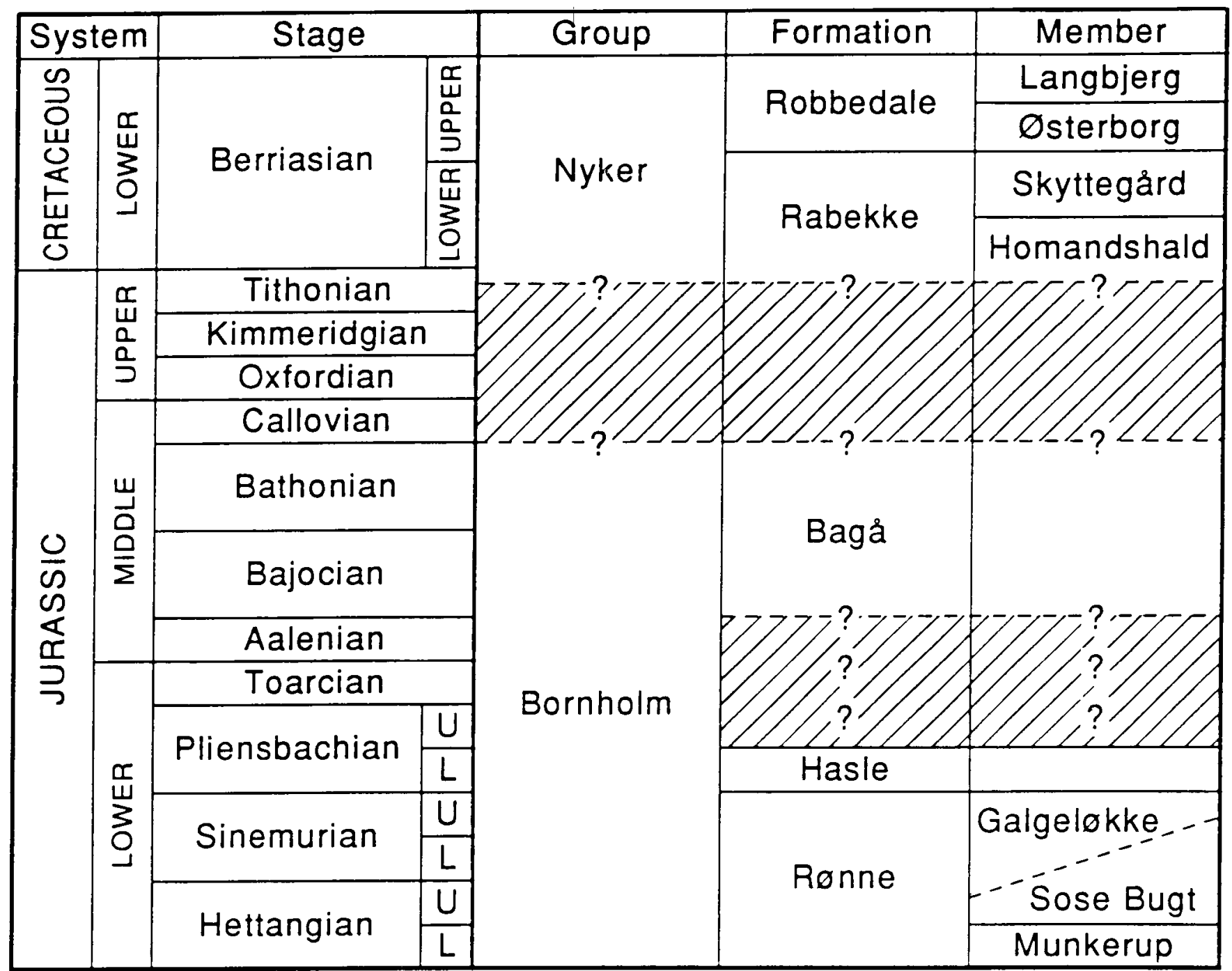

Fig. 4. Stratigraphy of the Jurassic and part of the Lower Cretaceous succession on Bornholm, modified from fig. 4 in Gravesen et al. (I982).

Hence its age can only be suggested on indirect evidence. The Skyttegård Member rests conformably on it. and has yielded ostracod assemblages which correlate with those from the German Oberer Münder Mergel and Serpulit (Christensen, 1963, 1966, 1974). These have been dated on the basis of ammonites (Casey, 1973), palynomorphs (Dörhöfer \& Norris, 1977; Herngreen et al., 1980) and other evidence (Allen \& Wimbledon, 1991) as early-?late Berriasian, although this differs from the Berriasian to carly Valanginian determination proposed by Pelzer \& Wilde (1987, fig. 2). Hence, the Homandshald Member is probably also Berriasian, but the possibility that it was deposited during the latest Jurassic (Tithonian/Portlandian) cannot be ruled out.

\section{Skyttegård Member}

The Skyttegård Member consists of variously coloured, but mainly dark grey, sandy structureless clay containing abundant particulate plant detritus, with subordi- nate silt, sand and lignite-bearing deposits. Rootlets and paleosols (red and yellow weathered horizons) also occur. It is from this part of the Rabekke Formation that Gry recovered a comparatively large number of megaspores which he noted were closely comparable to those described previously from the Wealden succession of southern England (Hughes, 1955, 1958) and coeval deposits in the Netherlands (Dijkstra, 1951). He nevertheless considered both the Rabekke and Robbedale Formations to be a Late Jurassic "Purbeck sequence" (Gry, 1969, pp. 85,86).

The absence of Upper Jurassic sediments on Bornholm has been attributed to erosion during the latest Jurassic (Gravesen et al., 1982). Deposition of the Nyker Group thus began with the coarse grained basal sediments of the possible earliest Cretaceous Homandshald Member. These are interpreted as fluviatile, valley-fill accumulations which pass rapidly upwards into lacustrine and swamp sands and clays of the Skyttegård Member, a few thin horizons of which indicate deposition in marginal marine conditions (Gravesen et al., 1982). 


\section{Robbedale Formation}

The overlying Robbedale Formation is well exposed in several sand pits on the Arnager-Sose Block but it is also found on the Nyker, Knudsker and Bøsth øj Blocks (Gravesen et al., 1982, p. 32, figs 7, 27). It consists of 8-40 m of mainly fine- to coarse-grained sands (NoeNygaard \& Surlyk, 1988). Trace fossils are common and evidence of bioturbation is abundant. Rootlets and plant debris occur at a number of levels, mainly in the Østerborg Member. This lower unit of the Robbedale Formation is generally finer grained than the overlying Langbjerg Member. It commences in bioturbated and Ophiomorpha-burrowed muddy, and clean, finegrained sand (Jux \& Strauch, 1968). These are regarded as shoreface (including beach, tidal flat and lagoonal) deposits that accumulated under the influence of tides and storms (Gravesen, 1977, 1982; NoeNygaard \& Surlyk, 1988; Surlyk \& Noe-Nygaard, 1988, fig. 14). The Langbjerg Member consists of medium to coarse pebbly, upper shoreface, foreshore and backshore sandwave and barrier-beach sands (Gravesen,1977, 1982; Noe-Nygaard \& Surlyk, 1988).

No age-diagnostic fossils have so far been found in either member, but since the basal part of the formation rests conformably on the mainly early Berriasian Rabekke Formation, and the lower beds of the overlying Jydegård Formation have been dated as late Berriasian, it follows that the Robbedale Formation is probably also of late Berriasian age (Christensen, 1963. 1974; Surlyk, 1980; Piasecki, 1984; Allen \& Wimbledon, 1991). 


\section{Material and methods}

Gry's collection of megaspores comprises more than 600 micropalacontological cell-slides in which all specimens are stored dry and unmounted. Any notes on his laboratory processing methods that he may have made have not been found. It is, however, likely that the spores were isolated from both outcrop and borehole samples simply by washing in water and sieving the generally poorly consolidated sediments. The fact that mineral detritus remains attached to many specimens suggests that little or no attempt was made to clean them using chemicals (e.g. hydrofluoric acid).

The species he idéntified are referred to in his paper in the course of discussing the ages of different exposures and borehole sections, and their occurrences in the Lower and Middle Jurassic are tabulated (Gry, 1969). The form of presentation is not, however, conducive to readily determining the stratigraphic origins of the assemblages. Since the nomenclature of both the sedimentary units and some of the megaspore species is also out of date, the records of occurrences in his paper are presented again here using current terminology as follows:

Munkerup clay [Munkerup Member of the Rønne Formation]

Horstisporites areolatus, H. harrisii, Nathorstisporites hopliticus, Verrutriletes franconicus

Sosevig beds [Sose Bugt Member of the Rønne Formation]

Horstisporites areolatus, H. harrisii, Nathorstisporites hopliticus, Trileites turbanaeformis [now T. candoris], Verrutriletes franconicus

Vellengsby (Vellensby) clay [Sose Bugt Member] Nathorstisporites hopliticus, Verrutriletes franconicus

Rønne area, white clay at Ormebæk [Sose Bugt Member]

Nathorstisporites hopliticus

Ronne area, below the marine (Lias $\gamma$; Hasle Formation) beds [Sose Bugt and ?Galgeløkke Members of the $\mathrm{R} \phi$ nne Formation]

Horstisporites areolatus, Trileites turbanaeformis

Rønne area, coal-bearing beds at Korsodde and Onsbæk [Bagå Formation]

Echitriletes russus [now E. hispidus], Erlansonisporites sparassis, Maexisporites soldanellus, Thomsonia phyl- lica [now Paxillitriletes phyllicus], Trileites murrayi, $T$. turbanaeformis

Boderne beds [Bagå Formation]

Hughesisporites sp., Thomsonia phyllica, Trileites murrayi, $T$. turbanaeformis

Sorthat beds [Bagå Formation]

Erlansonisporites sparassis, Horstisporites areolatus, Minerisporites volucris, Thomsonia phyllica, Trileites turbanaeformis

Bagå beds [Bagå Formation]

Aneuletes patera, Bacutriletes clavatus, B. corynactis, Erlansonisporites sparassis, Horstisporites harrisii, Maexisporites soldanellus, Thomsonia phyllica, Trileites murrayi, $T$. turbanaeformis

Levka beds, coal-bearing succession [Bagå Formation] Bacutriletes clavatus, B. corynactis, Erlansonisporites sparassis, Horstisporites areolatus, H. harrisii, Hughesisporites galericulatus, Minerisporites volucris, Thomsonia phyllica, T. cf. pseudotenella [now Paxillitriletes cf. pseudotenellus], Trileites turbanaeformis

Levka beds, deposits overlying coal-bearing succession [Bagå Formation]

Echisporites (sic.) russus in text, Echitriletes russus on fig. 7 in Gry, 1969), Erlansonisporites sparassis, Horstisporites harrisil, Minerisporites volucris, Thomsonia phyllica, Trileites murrayi, T. turbanaeformis

Purbeck beds [Rabekke and Robbedale Formations] Echitriletes lanatus, Hughesisporites galericulatus, Minerisporites marginatus, Striatriletes sulcatus, Thomsonia cf. pseudotenella, $T$. reticulata [now Paxillitriletes reticulatus], T. spp., Verrutriletes carbunculus [now $\mathrm{Ca}$ bochonicus carbunculus]

In order to describe Gry's material satisfactorily some of the specimens in the slides were removed so that they could be examined under a scanning electron microscope (SEM), an essential requirement of any modern analysis of the morphology of megaspores. Since the structure of the spore wall is of taxonomic significance, broken specimens and fragments considered likely to provide good cross-sections were also picked out for this purpose. All of the material selected was mounted on small, circular coverslips that had previously been glued to SEM stubs. Nail varnish was used 
as the adhesive for both fixing the coverslips to the stubs and for mounting the spores. The specimens were coated with gold or gold-palladium prior to being examined under a Phillips 515 SEM housed in the Geological Institute, Copenhagen University and/or a Jeol JSM 840 SEM in the Department of Biological Sci- ences, University of Wales, Aberystwyth. The slide collection continues to be retained in the biostratigraphic collections of the Geological Survey of Denmmark along with the SEM stubs bearing the specimens illustrated in this paper. 


\section{Systematic palynology}

\section{Introduction}

The spores that are described and illustrated below are grouped approximately according to overall morphology beginning with alete forms and those triradiate species that appear to have "smooth" exines when examined under a reflected light microscope. Weakly to strongly sculptured forms that are otherwise of "simple" overall appearance are then considered, followed by more complex species having prominent triradiate and/or equatorial flanges, long appendages on the proximal face and other characters. Such an informal organization enables probable natural relations to be taken into account more readily than if they are grouped according to Potonié's (1956 and later papers) widely-used formal system of morphological classification. This can be difficult to apply satisfactorily because of its hierarchical nature. It may artificially separate some taxa that are closely similar and bring together others that are better kept separate.

\section{Systematics}

* = taxon recorded by Gry (1969) although the nomenclature used is not necessarily the same.

ANEULETES Harris, 1961

Aneuletes discus sp. nov.

Pl. 1, figs 4-7; Pl. 2, fig. 1; Pl. 20, fig. 2

\section{Diagnosis:}

Spherical to subspherical bodies ranging from $c$. 240$460 \mu \mathrm{m}$ in maximum diameter (50 specimens). In reflected light they appear as virtually featureless black discs that may be slightly swollen on one surface but lack any sign of a germinal feature. Their walls are so thick that they are rarely damaged in any way. Under the SEM the outer surface of these discs is roughened but lacks distinctive sculpture. The wall of sectioned specimens is seen to be remarkably homogeneous.

Derivation of name:

Gr. discus; after the typical shape of the palynomorph

Holotype:

Pl. 20, fig. 2; slide HGHol/1, Borehole 244.105, 37.50$42.12 \mathrm{~m}$, Hasle Klinkerfabrik clay pit, Bagå Formation, Aalenian-Bathonian

Remarks:
Harris' (1961, p. 69) diagnosis of Aneuletes was intended for bodies "which resemble megaspores in size and structure, but have no furrows or cracks" (i.e. hollow sacs more than $200 \mu \mathrm{m}$ in diameter with thick walls and lacking germinal sutures or ridges). It is sufficiently broad-based to allow the inclusion of these forms in the genus. Their affinities are unknown; they may well not have anything to do with heterosporous plants.

Marcinkiewicz (1962, pl. 13, figs 6,7) illustrated two apparently disc-shaped microfossils in a paper devoted to Polish "Rhaeto-Liassic" megaspores. They were identified as questionable algae, but she did not discuss them. Kovach \& Dilcher (1988, p. 106, pl. 5, figs 11,12) referred similar forms to the acritarch Leiosphaeridia sp. B and considered their occurrence to indicate marine conditions of deposition. It appears from notes in pencil on a couple of his slides that Gry also thought that these bodies might have an algal origin. There is as yet, however, no unequivocal evidence in his material, which comes from a number of beds within the Baga Formation, to suggest that $A$. discus can be interpreted as a marine indicator.

There are some other apparently alete bodies in a few of Gry's slides, but these differ from $A$. discus in that they may be black or brown in colour in reflected light and appear to have somewhat thinner walls (recorded as only $6 \mu \mathrm{m}$ on one specimen); as a result they tend to be preserved as slightly crumpled (deflated) sacs and may be partly broken. Under the SEM their outer surfaces are seen to be granular (Pl. 2, fig. 2). Their biological affinities are also unknown.

Occurrence on Bornholm:

Bagå Formation

*Aneuletes patera Harris, 1961

1961 Aneuletes patera Harris, p. 69, fig. 22A-F

Pl. 1, figs 1-3; Pl. 20, fig. 1

Remarks:

Harris' (1961) specimens of $A$. patera were described as being nearly spherical, but with a flat to slightly concave area of circular outline on one side. This extends to about $1 / 2-2 / 3$ of the diameter of the spore, and within it are conspicuous swellings of rounded, elongate to slightly irregular outline which he considered to be local thickenings of the wall (hence verrucae and rugulae).

There are very few specimens of $A$. patera in Gry's 
collection, and these comprise part of only one assemblage from the Bagå Formation. Our illustration of this species is confined to a reflected light photograph of a single specimen ( $\mathrm{Pl} .20$, fig. 1) and some scanning electron micrographs of another specimen of probable Toarcian age from Anholt-4 borehole in the Kattegat to show the morphology of the taxon more clearly (Pl. 1, figs 1-3). Both compare closely in size and morphology to the type material from the Middle Jurassic of Yorkshire. The surface of the Anholt specimen is covered with granules and rugulae; the larger verrucate to rugulate swellings on the presumed proximal face are similarly sculptured.

Of the eight species of Aneuletes that have been documented to date (Batten \& Kovach, 1990), six are of Triassic age (Kovach \& Batten, 1989, p. 252) but only one of these, $A$. rotundus Fuglewicz, 1973, resembles A. patera. According to Fuglewicz (1973, p. 443 ), it is smaller, and lacks "knobs in concavity" and "small pits on spore surface". This latter character is unlikely to be of any significance in distinguishing species, and size is often an unreliable criterion (Harris, 1961 gives the size range for $A$. patera as $330-850 \mu \mathrm{m}$ whereas that for $A$. rotundus is $220-450 \mu \mathrm{m}$; Fuglewicz, 1973). The presence of "elongated ridge-like swellings, irregularly undulate" in the "concavity" may be the chief character that differentiates $A$. rotundus from $A$. patera.

The only other species, A. potoniei (Danzé \& Laveine, 1963) Candilier et al., 1982 is, in our opinion, doubtfully separated from $A$. patera on the basis of minor sculptural differences. The reported size range of $A$. potoniei ( $300-500 \mu \mathrm{m}$; Danzé \& Laveine, op. cit., p. 87) almost entirely overlaps that for $A$. patera, and the possession of an exine which shows numerous perforations $2 \mu \mathrm{m}$ in diameter (Candilier et al., op. cit., p. 2 ) is not of taxonomic significance, as noted above. Hence, although the specimen illustrated on $\mathrm{Pl}$. 1, figs 1-3 herein, is similar to those identified as $A$. potoniei on pl. 1, figs $18,23 \mathrm{a}$ and $23 \mathrm{~b}$ in Candilier et al., we prefer to identify it as $A$. patera (see also figures of $A$. patera in Marcinkiewicz, 1988, pl.23, figs 8-10 and elsewhere).

Occurrence on Bornholm:

Bagå Formation (Bagå beds)

BACUTRILETES van der Hammen, 1955 ex Potonié, 1956 emend. Banerji et al., 1984

${ }^{*}$ Bacutriletes sp. cf. B. clavatus Marcinkiewicz, 1960

1960 Bacutriletes clavatus Marcinkiewicz, p. 719, pl. 3, figs 6,7

Pl. 2, figs 3-5; Pl. 20, fig. 3

Remarks:

Marcinkiewicz's (1960) original description of this species, at the time questionably referred to Bacutriletes, was based on 6 specimens, all of which were damaged to varying degrees. She noted that the diameter of the spores, including the surface ornament, ranges between 350 and $400 \mu \mathrm{m}$, and that the sculptural elements are up to $65 \mu \mathrm{m}$ in length, rounded in cross-section, and narrower basally than at their tips. The triradiate mark was noted as not being evident, and probably obscured by the sculpture. She compared it with Verrutriletes litchii (Harris) Potonié, 1956, from which it differs mainly in being smaller and in having larger projections.

The illustrations of $B$. clavatus in Marcinkiewicz (1960, pl. 3, figs 6,7; 1971, pl.8, figs 3-9; 1988, pl. 19, figs 2-4) do not suggest a close resemblance to most of the specimens that Gry referred to this species (e.g. Pl. 20 , fig. 3 herein). The latter have shorter processes, seem to be closer to Biharisporites scaber Marcinkiewicz, 1960 and Striatriletes excavatus (Marcinkiewicz, 1962) Sweet, 1979, and may sometimes be difficult to distinguish from Echitriletes hispidus. The specimen illustrated on Pl. 2, figs 3-5 in this paper could even conceivably be a degraded Bacutriletes corynactis in which only the bases of the appendages are preserved. A specimen as strongly sculptured as that shown by Gry (1969, fig. 6.12) has not yet been found in his collection.

Almost all of the records of $B$. clavatus other than the few specimens recovered by Gry are Polish, documented principally by Marcinkiewicz from strata ranging in age from Pliensbachian to Bajocian (Batten \& Kovach, 1990).

Occurrence on Bornholm:

Bagå Formation (Bagå beds; Levka beds, coal-bearing succession)

* Bacutriletes corynactis (Harris, 1961) Marcinkiewicz, 1971

1961 Triletes corynactis Harris, p. 52, text fig. 15A-I

1971 Bacutriletes corynactis (Harris, 1961) Marcinkiewicz, p. 35, pl. 9, figs 4-7

Pl. 3, figs 1-5; Pl. 20, fig. 4

Remarks:

Gry (1969) referred this species to Bacutriletes but he failed to cite the basionym. The combination $B$. corynactis was, therefore, invalid according to the ICBN until 1971 when Marcinkiewicz correctly transferred the species from Triletes to Bacutriletes.

According to Marcinkiewicz, B. spicatus (Marcinkiewicz, 1962) Marcinkiewicz, 1971 differs in being smaller than $B$. corynactis (415-445 $\mu \mathrm{m}$, as opposed to 585-616 $\mu \mathrm{m}$ in diameter; Marcinkiewicz, 1971, pp. $34,35)$ and in having more delicate appendages. Harris (1961) recorded the diameter of his specimens, excluding the appendages, as ranging from $310-480 \mu \mathrm{m}$. This suggests that the two species cannot be readily differ- 
entiated on the grounds of size. The fact that the dimensions of the appendages supposedly differ according to Marcinkiewicz $(1971$, p. $57 ; 4-6 \mu \mathrm{m}$ in mean diameter, $60-80 \mu \mathrm{m}$ long in $B$. spicatus; $12-20 \mu \mathrm{m}$ in mean diameter, $50-60 \mu \mathrm{m}$ long in $B$. corynactis) may be sufficient to distinguish them, but our observations on the specimens Gry identified as B. corynactis suggest that their separation maty be difficult to maintain.

Scanning electron micrographs of the exoexine ( $c$. $5-10 \mu \mathrm{m}$ thick in the specimens examined) show it to be composed of a compact, comparatively robust, threedimensional network of sporopollenin threads (PI. 3, fig. 2). The surface of the appendages consists of a more open reticulum (PI. 3, figs 2,5), but in crosssection the reticulation is less obvious (Pl. 3, fig. 3). The intexine is a membraneous, more homogeneous layer $<1 \mu \mathrm{m}$ thick (Pl. 3, fig. 4).

Occurrence on Bornholm:

Bagå Formation (Bagå beds; Levka beds, coal-bearing succession)

\section{Bacutriletes onodios (Harris 1961) Hopkins \& Sweet 1976}

1961 Triletes onodios Harris, p. 53, figs 16I-L, 17A-E 1976 Bacutriletes onodios (Harris, 1961) Hopkins \& Sweet, p. 57 , pl. 11, figs $1-4$

Remarks:

Gry (1969) did not mention B. onodios in his paper, but handwritten notes on a few of his slides indicate that he considered it to be present in his collection. We are not, however, convinced that any definitely belong in this species, preferring instead to place them in comparison as follows.

Bacutriletes sp. cf. B. onodios (Harris, 1961) Hopkins \& Sweet, 1976

Pl. 2, fig. 6; Pl. 4, figs 1-5

Remarks:

The specimens in the collection that Gry identified as $B$. onodios, and which we compare with this species, are closest morphologically to that of the single "unusually small specimen" figured by Harris (1961, fig. 16L). Despite the degree of morphological variation allowed by Harris' circumscription, they may not, however, belong to this species. A few (c.g. that shown on Pl. 2, fig. 6) might be better placed in Verrutriletes. One of the forms illustrated (Pl. 4, figs 1,2) is closely similar to the specimen identified by Kovach \& Dilcher (1988, pl. 1, figs 3-6) as B. greenlandicus (Miner, 1932) Potonié, 1956 and, to a lesser extent, to Verrutriletes dasyplocoides Schulz \& Noll, 1987; both of these were described from Cretaceous deposits.

In common with a number of other verrucate to rugulate spores whose wall structure has been examined (c.g. Verrutriletes compositipunctatus, $V$. dubius and Striatriletes minimus in Batten, 1988), the exoexine is seen to be spongiose and underlain by a thin, more homogeneous intexine (Pl. 4, figs 3-5).

Occurrence on Bornholm:

Bagå Formation

\section{CABOCHONICUS Batten \& Ferguson, 1967}

${ }^{*}$ Cabochonicus carbunculus (Dijkstra, 1949) Batten \& Ferguson, 1987

1949 Triletes carbunculus Dijkstra, p. 22, pl. 1, fig. 12 1987 Cabochonicus carbunculus (Dijkstra, 1949) Batten \& Ferguson, p. 72, pl. 1, figs 1-4; pl. 2, figs $2-8$; pl. 3, figs $1-7$; pl. 4, figs $1-6$

Pl. 3, figs 6-8; Pl. 20, figs 5,6

\section{Remarks:}

This species was not illustrated by Gry (1969) but it was referred to in the text of his paper as Verrutriletes carbunculus. There are only a few fragments and even fewer complete specimens of this species in his collection. The morphology of the remains is closely comparable to that of the spores described by Dijkstra (1949, 1951) from Cretaceous deposits of the Netherlands and the UK (see Batten \& Ferguson, 1987; Batten, 1988).

Occurrence on Bornholm:

Rabekke and Robbedale Formations (Purbeck beds).

ECHITRILETES van der Hammen, 1955 ex Potonié, 1956

${ }^{*}$ Echitriletes hispidus Marcinkiewicz, 1960

1960 Echitriletes hispidus Marcinkiewicz, p. 719, pl. 4, fig. 1

Pl. 20, fig. 7

Remarks:

Marcinkiewicz's (1960) original description of this species was based on two specimens 530 and $575 \mu \mathrm{m}$ in diameter. The spore was reported to be subcircular in outline with a low, slightly wavy triradiate ridge some $17 \mu \mathrm{m}$ wide extending to about $1 / 2$ the radius of the spore, and the proximal and distal surfaces to be covered by numerous hair-like projections about $25 \mu \mathrm{m}$ long and $7 \mu \mathrm{m}$ in basal width. An additional feature of the proximal face is the presence of "bumps" on the contact areas.

Gry (1969) appears to have found very few specimens of this species, insufficient to enable any to be examined under the SEM for this paper. He recorded them as Echitriletes russus Harris, 1961, but this species was shown by Marcinkiewicz (1971, p. 35) to be a junior synonym of $E$. hispidus. They appear to be closely similar in morphology to the specimens illustrated by Marcinkiewicz (1971, pl. 10, figs 3-6). The spore illustrated by Sweet (1979) has longer sculptural 
elements than either Gry's specimens or those figured by Marcinkiewicz.

Occurrence on Bornholm:

Bagå Formation (Korsodde and Onsbæk, coal-bearing beds; Levka beds overlying coal-bearing succession)

${ }^{*}$ Echitriletes lanatus (Dijkstra, 1951) Potonié, 1956

1951 Triletes lanatus Dijkstra, p. 11, pl. 2, fig. 22

1956 Echitriletes lanatus (Dijkstra, 1951) Potonié, pp. 36,37

Pl. 4, figs 6-8; Pl. 20, fig. 8

Remarks:

Gry (1969) mentioned this species in connection with the "Purbeck beds", but did not illustrate it. There are fewer than six specimens in his collection, and these are not only partly degraded but also appear to differ to some extent from the type material in being sculptured with shorter papillae (cf. for example, specimen of $E$. lanatus in Batten, 1975, pl. 13, fig. 4). Nevertheless, there is no reason to doubt their identification as $E$. lanatus. Scanning electron microscopy of the cross-section of a wall of a single fragment reveals an outer, spongiose exoexine underlain by a more homogeneous, membraneous intexine (Pl. 4, fig. 8).

Occurrence on Bornholm:

Rabekke and Robbedale Formations (Purbeck beds)

\section{ERLANSONISPORITES Potonié, 1956}

${ }^{*}$ Erlansonisporites sparassis (Murray, 1939) Potonié, 1956

1939 Triletes sparassis Murray, pp. 480-482, figs 3,4

1956 Erlansonisporites sparassis (Murray, 1939) Potonié, p. 47

1961 Triletes sparassis Murray, 1939 emend. Harris, pp. 57-60, fig. 18A-D

Pl. 5, figs 1,2; Pl. 20, figs 9,10

Remarks:

In common with many identifications of megaspores, the morphology of the specimens that have been attributed by different authors to $E$. sparassis may sometimes appear to be at variance with the characters given in the original description. It is, in fact, a very variable form which is often difficult to identify with confidence. Harris (1961) found it necessary to emend the diagnosis to encompass a wider morphological range than was allowed for in Murray's description. Salient characters are a spore body that is nearly spherical, having a diameter that ranges from $300-850 \mu \mathrm{m}$, a triradiate ridge that is often rather sinuous and usually broadbased, but becoming membraneous upwards to a maximum height of about $75 \mu \mathrm{m}$, and a surface that is typically sculptured with a coarse network of irregular ridges up to $50 \mu \mathrm{m}$ high. In some specimens the height of the muri matches that of the triradiate ridge, rendering it rather difficult to distinguish, whereas in others the ridge is prominent (cf. Pl. 5, figs 1,2).

Occurrence on Bornholm:

Bagå Formation (Korsodde and Onsbæk, coal-bearing beds; Sorthat beds; Bagå beds; Levka beds, coal bearing succession; Levka beds above coal-bearing succession).

HENRISPORITES Potonié, 1956 emend. Binda \& Srivastava, 1968

Henrisporites bornholmensis sp. nov.

Pl. 6, figs 1-8; Pl. 20, figs 19,20

Diagnosis:

Megaspore trilete, rounded triangular in equatorial outline; maximum diameter in polar view excluding zona $290-400 \mu \mathrm{m}$ (50 specimens). Laesurae extend to equator of body, bordered by membraneous elevated lips $30-50 \mu \mathrm{m}$ high which extend onto, and merge with zona. Width of zona $40-70 \mu \mathrm{m}$; outer margin continuous. Sculpture comprises spines that are evenly distributed over both proximal and distal surfaces, rounded in outline, and with rounded to pointed tips; up to $7 \mu \mathrm{m}$ in basal width and $50 \mu \mathrm{m}$ high. Triradiate flange and zona are of similar dimensions, and both have fairly smooth, continuous, margins.

Exoexine $c .10 \mu \mathrm{m}$ thick, comprising a meshwork of sporopollenin threads orientated mainly subparallel to outer surface of spore. Alignment of threads is also evident on zona (Pl. 6, fig. 8) and triradiate flange where they are mainly parallel to surface of these structures. Intexine is a thin $(c .2 \mu \mathrm{m})$, more homogeneous membrane (Pl. 6, fig. 6).

Derivation of name:

After the island of Bornholm

Holotype:

Pl. 20, fig. 19; slide HGHol/2, Borehole 246.207, 26.00

$\mathrm{m}$, Robbedale Formation, upper Berriasian

Remarks:

The spore body of species of Henrisporites, as emended by Binda \& Srivastava (1968), is ornamented with granules, verrucae, rugulae, cones or spines, whereas most forms of Minerisporites are at least partly reticulate.

The structure of the wall of $H$. bornholmensis is closely comparable to that of Minerisporites marginatus (cf. Batten, 1969, pl. 67, fig. 12; Kovach \& Dilcher, 1988, pl. 3, fig. 10) and similar forms (e.g. Minerisporites patagonicus Archangelsky \& Villar de Seoane, 1989, pl. 2, fig. 6).

With the exception of $H$. delicatus and $H$. triassicus (see below), all of the other species of Henrisporites that have been described have come from Barremian and younger Cretaceous rocks. Of these, $H$. undulatus (Dijkstra, 1951) Potonié, 1956 is closest morpholog- 
ically to $H$. bornholmensis, but its sculptural elements are more irregularly dispersed, variable in length, and mainly flattened rather than rounded in cross-section; the distal surface is also more densely sculptured. Henrisporites affinis (Dijkstra, 1951) Potonié, 1956 has shorter, more irregular sculptural elements which, on the proximal face, comprise rugulae in part; the margin of the zona is also spinose. H. angustus Tschudy, 1975 has a much narrower zona and a rather "wrinkled" distal surface. H. rarus Li \& Batten in Li et al., 1987 differs in several ways, including in being significantly larger, in having a more triangular outline, and in bearing shorter and more widely scattered sculptural elements. The three species described by Binda \& Srivastava (1968), $H$. elkwaterensis, $H$. granulatus and $H$. sheilae, have shorter spines and less pronounced triradiate flanges. Other Cretaceous species $(H$. elegans Gamerro, 1977; H. heteracanthus Gamerro, 1975; $H$. musachioi Gamerro, 1977; H. ollerensis Lachkar in Floquet \& Lachkar, 1979) and the two Triassic forms (H. delicatus Marcinkiewicz, 1978 and H. triassicus Kozur, 1973) are also not closely comparable in morphology.

Occurrence on Bornholm:

Robbedale Formation (Purbeck beds)

Henrisporites undulatus (Dijkstra, 1951) Potonié, 1956

1951 Triletes undulatus Dijkstra, p. 13, pl. 2, figs 1,5

1956 Henrisporites undulatus (Dijkstra, 1951) Potonié, p. 68

Pl. 5, figs $3,4,6,8$

Remarks:

Gry appears to have included this form in Echitriletes hispidus, but the presence of a zona and triradiate flange renders the determination inappropriate. Its sculpture is more regular than that of $H$. affinis (Dijkstra, 1951) Potonié, 1956. It differs from H. bornholmensis in that the triradiate flange is subtended by hair-like appendages, and both the zona and the sculptural elements generally have a more fibrous appearance.

Occurrence on Bornholm:

Robbedale Formation (Purbeck beds)

\section{Henrisporites sp.}

\section{Pl. 5, figs 5,7}

Remarks:

This species resembles Henrisporites triassicus Kozur, 1973 to some extent, but it may be rather closer to another Triassic form, Narkisporites insignis Fuglewicz, 1973. This has a similar appearance in polar view; indeed, apart from the fact that it is sculptured with rather more numerous spinose elements, the descrip- tion given by Fuglewicz $(1973$, pp. 429,430) could also be applied to the specimen illustrated here.

Occurrence on Bornholm:

Rabekke and Robbedale Formations (Purbeck beds)

HORSTISPORITES Potonié, 1956

${ }^{*}$ Horstisporites areolatus (Harris, 1935) Potonić, 1956

1935 Triletes areolatus Harris, pp. 158,159, pl. 26, figs 3,10, text-fig. 51A-F

1956 Horstisporites areolatus (Harris, 1935) Potonié, 1956 , p. 45.

Pl. 7, figs 1-8; Pl. 8, fig. 1; Pl. 20, figs 11,12

\section{Description:}

In polar view, spore circular to subcircular in equatorial outline. Triradiate ridges up to $c .20 \mu \mathrm{m}$ high and $30 \mu \mathrm{m}$ in basal width, extend to $c .3 / 4$ of radius (Pl. 7, figs 1,3). Exine rather uniformly reticulate but becoming less pronounced adjacent to proximal pole; contact areas sometimes delineated by an alignment of muri (PI. 7, figs 3,4$)$. Size of most specimens falls within lower part of range for the species, many being $c$. $600 \mu \mathrm{m}$ in diameter. In cross-section, muri are rounded to flattopped or taper to a blunt tip (Pl.7, fig. 6), and are up to $c .6 \mu \mathrm{m}$ wide and $15 \mu \mathrm{m}$ high. Lumina are rounded to polygonal in outline, and up to $20 \mu \mathrm{m}$ in maximum diameter.

Most specimens are proximo-distally compressed. Damaged spores and fragments reveal that exine is essentially two-layered. Exoexine is between 10 and 20 $\mu \mathrm{m}$ thick, excluding muri, and composed of compactly spongiose sporopollenin. Beneath is a thin $(1-2 \mu \mathrm{m})$ intexine comprising a reticulate meshwork of sporopollenin threads orientated mainly parallel to inner surface of wall (Pl. 7, figs 5,7,8) giving it a laminated appearance.

\section{Remarks:}

It has not been possible so far to obtain any scanning electron micrographs at high magnifications that clearly show the construction of these wall layers. Assuming, however, that the close morphological resemblance of $H$. kendallii with $H$. areolatus means that they are also structurally similar, the electron micrographs of the wall of the former appear to confirm these observations, particularly with respect to the intexine (see description of $H$. kendallii below).

$H$. areolatus is very similar to $H$. casses and $H$. kendallii. According to Harris (1961) they are distinguished mainly on the basis of size, wall thickness and the "mesh size" of the reticulum, although he pointed out (Harris, 1961, p. 63) that the last of these may well be related to overall size. This does indeed seem to be the case. The only significant difference between $H$. areolatus and $H$. kendallii is their size, given as $600-$ $1400 \mu \mathrm{m}$ and $320-510 \mu \mathrm{m}$ respectively by Harris. The 90 
$\mu \mathrm{m}$ difference between the smallest $H$. areolatus and the largest $H$. kendallii is not significant because specimens of intermediate dimensions may be found. $H$. casses is significantly larger than $H$. kendallii, the sculpture is proportionally more enlarged, and the exine considerably thicker. It overlaps $H$. areolatus in size to a considerable degree, its range being between 890 and $1900 \mu \mathrm{m}$ according to Harris.

When present in large numbers in his samples from the Middle Jurassic of Yorkshire, Harris (1961) had no difficulty in identifying the species. The assemblages tended to be of rather uniform size and appearance, only one of the three types normally being present at a particular locality. This uniformity is also apparent in Gry's assemblages although few comprise more than 50 specimens. Most are comparatively small and either diminutive examples of $H$. areolatus or assignable to $H$. kendallii. In large assemblages, specimens ranging in size between 510 and $600 \mu \mathrm{m}$ may be identified as one or other species depending on the mean diameter of the "population" as a whole, but when found as isolated individuals, the basis for a decision on the species to which they should be referred becomes arbitrary.

\section{Occurrence on Bornholm:}

Munkerup Member (Munkerup clay), Sose Bugt Member (Sosevig beds), ?Galgeløkke Member, Bagå Formation (Sorthat beds; Levka beds, coal-bearing succession)

Horstisporites casses (Harris, 1961) Marcinkiewicz, 1980

1961 Triletes casses Harris, pp. 60,61, fig. 19D,F

1980 Horstisporites casses (Harris, 1961) Marcinkiewicz, p. 51, pl. 5, figs $1-3$; pl. 6, figs 1,2

Remarks:

Only one fragment of $H$. casses has been encountered in Gry's collection. As noted above, this species is similar to $H$. areolatus but much larger and sculptured with proportionally wider lumina and broader and higher muri.

Occurrence on Bornholm:

A single sample from the Bagå Formation

*Horstisporites harrisii (Murray, 1939) Potonié, 1956

1939 Triletes harrisii Murray, p. 480, figs 1,2

1956 Horstisporites harrisii (Murray, 1939) Potonié, p. 45

Pl. 8, figs 2-8; Pl. 20, fig. 13

Remarks:

As pointed out by both Gry (1969) and Bertelsen \& Michelsen (1970), Jung's (1960) criteria for separating Horstisporites semireticulatus Jung, 1960 from H. harrisii lost their significance when Harris (1961) emended the diagnosis of the latter. The specimens in Gry's collection are rounded in equatorial outline and have a prominent triradiate ridge. They are sculptured with verrucae and ridges on the contact areas which give way to an irregularly reticulate wall equatorially and distally (e.g., Pl. 8, figs 6,8). This may be clearly developed or rather poorly defined. Curvaturae may be weakly developed, manifested mainly by a change to different ornamentation where the lumina, if any, are smallest and the muri are lowest. Harris (1961) noted that the proximal surface bears smaller tubercles than the distal face, but this is not necessarily so; occasionally the proximal sculpture can be more prominent.

$H$. harrisii can be difficult to separate from Erlansonisporites sparassis, as Harris (1961) also found; he presumed the most "difficult" specimens to be immature or unusual forms of other species. The spores that Gry labelled as $H$. harrisii show quite a variety of sculpture ranging from small verrucae (tubercles) to ridges forming a reticulum. The specimens figured as H. harrisii by Marcinkiewicz (1980, pl. 5, figs 4,5) are similar. The morphology of the mainly Cretaceous species $H$. reticuliferus (Dijkstra, 1951) Potonié, 1956 resembles that of $H$. harrisii but it does not bear verrucae on the proximal face.

Occurrence on Bornholm:

Munkerup Member (Munkerup clay), Sose Bugt Member (Sosevig beds), Bagå Formation (Bagå beds; Levka beds, coal-bearing succession; Levka beds, above coalbearing succession)

Horstisporites kendallii (Harris, 1961) Kempf, 1972

1961 Triletes kendallii Harris, pp. 63,64, fig. 19A-C 1972 Horstisporites kendallii Kempf, p. 152, figs 14-17

Remarks:

The distinction of this species from morphologically similar $H$. areolatus and $H$. casses is discussed above (see $H$. areolatus). The single specimen from the Bagå Formation photographed under reflected light by Kempf (1972) is a little under $400 \mu \mathrm{m}$ in diameter. The transmission electron micrographs of sections through the exine of this species show that it comprises a thick $(10-15 \mu \mathrm{m}$, excluding sculpture) exoexine (= perine in Kempf, op. cit., p. 156), the outer part of which consists of more densely packed sporopollenin threads than the inner part. In addition, the direction of orientation of the threads is irregular to mainly normal to the surface in the outer zone, but parallel to it beneath, giving it a somewhat laminated (lamellate) appearance. The intexine (= exine in Kempf) is very thin (c. 0.5 $\mu \mathrm{m})$. It is attached to, and structurally merges with, the inner zone of the outer wall, but the lamination is more pronounced.

H. kendallii has been reported previously from only a few localities (Batten \& Kovach, 1990). Where the ages of the occurrences are known fairly accurately, 
these are confined to the Middle Jurassic, AalenianBajocian.

Occurrence on Bornholm:

Munkerup Member (Munkerup clay), Sose Bugt Member (Sosevig beds), ?Galgeløkke Member, Bagå Formation (Sorthat beds; Levka beds, coal-bearing succession)

Horstisporites planatus (Marcinkiewicz, 1960) Marcinkiewicz, 1971

1960 Maexisporites planatus Marcinkiewicz, p. 718, pl. 3 , fig. 2

1971 Horstisporites planatus (Marcinkiewicz, 1960) Marcinkiewicz, pp. 36,57, pl. 12, figs 1-9

Pl. 9, figs 1-5; Pl. 20, figs 14-16

Remarks:

Marcinkiewicz's (1960, p. 718) original description of this species was based on "about 10 specimens in a very damaged state". The diameter of the spores was noted to range from $240-465 \mu \mathrm{m}$ (mainly $368-400 \mu \mathrm{m}$ ). Other characters recorded were its subcircular outline, clearly defined triradiate suture up to $20 \mu \mathrm{m}$ high (i.e. bordered by raised lips), and the presence of a subequatorial flange $10 \mu \mathrm{m}$ wide. The surface of the spore was described as lightly granular (cf. Pl. 9, fig. 5 herein). Subsequent to maceration of various specimens at a later date and examination in transmitted light, Marcinkiewicz (1971) realised that the sculpture was finely reticulate rather than granulate. As a result, she decided that the species would be more appropriately placed in Horstisporites. At the same time she made several modifications and additions to her earlier description of the species as follows: a greater maximum diameter $(490 \mu \mathrm{m})$; width of triradiate ridge, which may be slightly sinuous, $10-15 \mu \mathrm{m}$; arcuate ridges similarly developed, joining with the ends of the triradiate ridges where they occasionally form minute auriculae; exine $6-8 \mu \mathrm{m}$ thick; reticulum consists of a network of muri c. $3 \mu \mathrm{m}$ wide and up to $2-6 \mu \mathrm{m}$ high surrounding lumina mainly $4-10$, but up to $30 \mu \mathrm{m}$, in diameter.

Occurrence on Bornholm:

Sose Bugt Member

\section{HUGHESISPORITES Potonié, 1956}

*Hughesisporites galericulatus (Dijkstra, 1951 emend. Hughes, 1955) Potonié, 1956

1951 Triletes gcilericulatus Dijkstra, p. 14, pl. 2, fig. 16; pl. 3, fig. 5

1955 Triletes galericulatus Dijkstra, 1951 emend. Hughes, pp. 212,213, pl.12, figs 1,2

1956 Hughesisporites galericulatus (Dijkstra, 1951 emend. Hughes, 1955) Potonié, p. 71

Pl. 9, figs 6-9; Pl. 10, figs 1,3 ; Pl. 20, fig. 18

\section{Remarks:}

Dijkstra (1951) described H. galericulatus as having a gula, in common with a number of Carboniferous megaspores, but Hughes (1955) showed that the construction of the proximal area differs from this in that it consists of triradiate ridges surrounded by pointed appendages; hence his emendation.

The morphology of the species is remarkably consistent even though specimens are seldom common in assemblages. Those in Gry's collection are entirely typical in being between 300 and $400 \mu \mathrm{m}$ in diameter, and in having a rounded to rounded-triangular equatorial outline, a prominent triradiate ridge, and a spinose contact face. The spines arch towards the ridge and may be discrete or connected along part or most of their length.

The exoexine is $c$. $18-20 \mu \mathrm{m}$ thick and composed of tightly packed sporopollenin threads that make the wall in cross-section look granular at magnifications of $c$. $\times 2000$ (P1. 10, fig. 3). At higher power the outer "smooth" surface appears foveolate. The intexine may be $1-2 \mu \mathrm{m}$ thick and of more homogeneous construction.

Occurrence on Bornholm:

Bagå Formation (Levka beds, coal-bearing succesion), Rabekke and Robbedale Formations (Purbeck beds)

\section{*Hughesisporites variabilis Dettmann, 1961}

1961 Hughesisporites variabilis Dettmann, p. 76, pl. 1, figs $15-20$, pl. 2 , fig. 1 .

Pl. 10, figs 2, 4-8; Pl. 20, fig. 17

\section{Remarks:}

Gry referred informally in his records to specimens of this species as "sourface" or "wrinkle face", and in his 1969 paper he noted it to be a new species of Hughesisporites. Reference to this genus is based on the appearance of the proximal face, the contact areas of which bear radially arranged, sinuous muri. Gry's specimens as viewed in reflected light and under the SEM are very similar to the Rhaetian material from Tasmania on which Dettmann (1961) based $H$. variabilis. They differ in having a gently undulating wall with a smooth surface equatorially and distally, although at high magnifications the surface is seen to be finely granular. They are also significantly larger, having a maximum diameter of between 620 and $700 \mu \mathrm{m}$ as opposed to between 200 and $420 \mu \mathrm{m}$ for dry, and 500 $\mu \mathrm{m}$ for "cleared" (translucent) Tasmanian specimens.

Hughesisporites ionthus Harris, 1935 is similar to $H$. variabilis but, according to Dettmann (1961), differs in having a ridge that delineates the lower margin of the contact faces. Dettmann also regarded the cavate exine of her species to distinguish it from $H$. ionthus. Gry's specimens are closer in size to those found by Harris, for which a diameter of $500-600 \mu \mathrm{m}$ was documented 
(Harris, 1935, p. 166), but they appear to differ in having a more delicate proximal sculpture and perhaps also a more sinuous triradiate ridge.

Hughesisporites pustulatus Marcinkiewicz, 1962 is also similar. This species was described from the Lower Jurassic (Lias $\gamma$ ) of Poland on the basis of a single specimen $300 \mu \mathrm{m}$ in diameter. The triradiate ridge was noted to be $c .20 \mu \mathrm{m}$ wide and to reach $3 / 4$ of the spore radius in length. The surface of the contact area was described as being covered with small knobs (Marcinkiewicz, 1962, p. 493). Its size range was given as $300-400 \mu \mathrm{m}$ in a later publication (Marcinkiewicz, 1981, p. 186). Hence, it is smaller than the species recorded here as $H$. variabilis, but whether only a single taxon is, in fact, involved is not clear.

Occurrence on Bornholm:

Bagå Formation (Boderne beds)

\section{MAEXISPORITES Potonié, 1956}

Maexisporites sp. cf. M. misellus Marcinkiewicz, 1962

1962 Maexisporites misellus Marcinkiewicz, pp. 473, 491 , pl. 2, figs 6,7

PI. 11, figs 1,2

Remarks:

Marcinkiewicz (1962, p. 491) described this species as having a "hardly discernible" tetrad scar and a "faintly granular" sculpture. The specimens she illustrated (1962, pl. 2, figs 6,7) suggest that the triradiate ridge is more prominent and the sculpture more strongly developed than is implied by her description, and this is confirmed by two further illustrations in a later paper (Marcinkiewicz, 1971, pl. 3, figs 2,3).

Hitherto, all records of $M$. misellus have been Rhaetian (Kovach \& Batten, 1989), which means that by identifying the few specimens from the Bagå Formation here as this species, its stratigraphic range is immediately extended. On the other hand, the morphology of the species is not so distinctive, and its present apparently very restricted range may be misleading. In the circumstances, the most appropriate course of action seems to us to merely compare Gry's specimens with M. misellus.

Occurrence on Bornholm:

Bagå Formation

*Maexisporites soldanellus (Dijkstra, 1951) Potonié, 1956

1951 Triletes soldanellus Dijkstra, p. 10, pl.2, fig. 17

1956 Maexisporites soldanellus (Dijkstra, 1951) Potonié, p. 25

Pl. 11, figs 3-8; P1. 21, figs 1,2

Remarks:

Specimens of this species are very common in the Bagå
Formation. They are rather more strongly sculptured on the contact areas, and sometimes also elsewhere, than those on which the species is based (personal observation). Dijkstra (1951, p. 10) described the sculpture as "finely granulated, granules about $2 \mu$ in diameter". Most seem, however, to be within what is reasonable to regard as an acceptable range of morphological variation for the species. Specimens sculptured with granules and/or small rugulate elements have, therefore, been included in $M$. soldanellus.

The exoexine is composed of a densely packed, comparatively robust network of sporopollenin (Pl. 11, fig. 5) which gives the surface of the spore a reticulate appearance at high magnification (Pl. 11, fig. 6).

Occurrence on Bornholm:

Bagå Formation (Korsodde and Onsbæk, coal-bearing beds; Bagå beds)

MINERISPORITES Potonié, 1956

* Minerisporites marginatus (Dijkstra, 1951) Potonié, 1956

1951 Triletes marginatus Dijkstra, p. 13, pl. 3, fig. 11 1956 Minerisporites marginatus (Dijkstra, 1951) Potonié, p. 68

Pl. 12, figs 1,$2 ; \mathrm{pl} .21$, figs 3,4

Remarks:

The spores included here display the characters of the species as described by Dijkstra (1951).

Occurrence on Bornholm:

Rabekke and Robbedale Formations (Purbeck beds)

Minerisporites sp. cf. M. marginatus (Dijkstra, 1951) Potonié, 1956

Pl. 12, figs 3,4

Remarks:

Some of the specimens Gry (1969) referred to $M$. marginatus are more weakly sculptured than those on which Dijkstra based the species. They are, therefore, only compared with it here.

Occurrence on Bornholm:

Rabekke and Robbedale Formations (Purbeck beds)

Minerisporites richardsonii (Murray, 1939) Potonié, 1956 emend. Harris, 1961

1939 Triletes richardsoni Murray, pp. 482,484, figs 9,10

1956 Minerisporites richardsoni (Murray, 1939) Potonié, p. 68

1961 Triletes richardsoni Murray, emend. Harris, p. 46 , fig. 13A-H

Pl. 12, figs 5-8; Pl. 13, fig. 1; Pl. 21, fig. 5

Remarks: 
The range of morphological variation that Harris (1961) considered to be acceptable for this species is quite wide as shown in his figures, and as is evident from our examination of his slides. In most respects the morphology of the specimens in Gry's collection accords with Harris' emended diagnosis. They do differ slightly, however; whereas the sculpture of the proximal face consists of meandering ridges forming an irregular reticulum, that on the distal face may be better defined and more regular in form than Harris allowed. On the other hand, the development of spines where the muri of the reticulum merge conforms with his description; these may be elevated to form processes up to $25 \mu \mathrm{m}$ long, the longest structures usually being close to the triradiate flange.

Minerisporites institus Marcinkiewicz, 1960 is very similar and was placed in synonymy with $M$. richardsonii by Marcinkiewicz (1971). More recently she decided, however, that they are not the same because $M$. institus is larger and has (more) strongly developed auriculac (Marcinkiewicz, 1980).

Occurrence on Bornholm:

Bagå Formation

\section{*Minerisporites volucris Marcinkiewiz, 1960}

1960 Minerisporites volucris Marcinkiewicz, p. 723, pl. 7 , figs $1-3$

PI. 13, figs 2-5,7,8; PI. 21, fig. 6

Remarks:

Marcinkiewicz's (1960) diagnosis of this species was based on observations of only one specimen $385 \mu \mathrm{m}$ in diameter. The following characters were noted (freely translated and modified from the original description in Polish): spore body almost spherical; rays of triradiate suture extend to equator, bordered by transparent flanges about $50 \mu \mathrm{m}$ in height; these merge with an equatorial flange (zona) to form delicately perforated auriculae extending to about $130 \mu \mathrm{m}$ away from spore body; sculpture comprises numerous spines c. $55 \mu \mathrm{m}$ long and $c .15 \mu \mathrm{m}$ in basal width.

Gry's specimens clearly belong here. Marcinkiewicz remarked that the species most closely resembles Minerisporites ales (Harris, 1935) Potonié, 1956, differing from it primarily in possessing shorter and wider spines and in having a lower triradiate flange.

Occurrence on Bornholm:

Bagå Formation (Sorthat beds; Levka beds, coal-bearing succession; Levka beds, above coal-bearing succession)

\section{Minerisporites sp.}

Pl. 13, fig. 6; Pl. 14, fig. 1

Remarks:

This is a small species with an unevenly roughened/ scabrate surface and a fairly massive triradiate ridge. Henrisporites delicatus Marcinkiewicz, 1978 is normally spinose but Marcinkiewicz (1983) recovered specimens which lack any sculpture, and these appear to be similar to the spores illustrated here. The resemblance is, however, only superficial because the absence of spines on $H$. delicatus is interpreted to be a result of exinal degradation, and not a primary feature (Marcinkiewicz, 1983). This species is, in any case, much larger than the spores from Bornholm, whose diameters range from $230-300 \mu \mathrm{m}$.

Occurrence on Bornholm:

Bagå Formation

NATHORSTISPORITES Jung, 1958

*Nathorstisporites hopliticus Jung, 1958

1958 Nathorstisporites hopliticus Jung, pp. 121-123, pl. 3 , figs $1,5,6,9-11$

Pl. 14, figs 2-8; Pl. 21, fig. 7

Remarks:

Specimens of this species consist of a spheroidal spore body with elevated, membraneous lips which obscure the laesurae. The basal part of the triradiate flange is of the same construction as the outer surface of the body, but the upper part appears solid and deeply incised. It is commonly difficult to distinguish the flange from adjacent appendages.

The contact faces are delineated by a low elevation that is subparallel to the equator, or by an alignment of coni or spines. The tips of these are often divided, and the surface of the wall between the large spines (up to $50 \mu \mathrm{m}$ high and c. $30 \mu \mathrm{m}$ in basal diameter) is also sculptured with small spines up to $10 \mu \mathrm{m}$ high.

Bertelsen \& Michelsen (1970) attempted to divide their collection of Nathorstisporites specimens into two groups according to the characters as set out by Jung (1958) for his two species, $N$. hopliticus and $N$. peltasticus, but found that they were left with a large, unassignable residual group. Another attempt at classification on the basis of distal sculpture being verrucate or capillate was also given up because the number of intermediate forms also made this impossible; hence, they recorded all their specimens as $N$. hopliticus.

On the basis of a TEM examination of a specimen from the Lower Jurassic of Bornholm, Kempf (1972) found the exoexine (perine in Kempf) to be c. $20 \mu \mathrm{m}$ thick, excluding the sculpture, and its fine structure to differ from that of Paxillitriletes. The inner part of the wall was shown to comprise sporopollenin threads that are approximately $0.3 \mu \mathrm{m}$ in diameter and arranged subparallel to the inner surface of the wall, whereas those of the outer zone are thicker and form an irregular network from which conical protruberances extend a further $20 \mu \mathrm{m}$ and more, terminating in an almost solid sporopollenin mass. The elongate, often branched 
processes that dominate the proximal surface close to the triradiate flange have hollow bases and, except where they merge with the reticulate outer surface of the exoexine, also consist largely of dense, homogeneous sporopollenin.

Occurrence on Bornholm:

Munkerup Member (Munkerup clay), Sose Bugt Member (Sosevig beds; Vellengsby clay; Ormebæk, white clay)

\section{PAXILLITRILETES Hall \& Nicolson, 1973}

Paxillitriletes kristinae sp. nov.

Pl. 15, figs 1-8; Pl. 16, fig. 1; Pl. 21, fig. 8

\section{Diagnosis:}

Megaspore, trilete; mean maximum diameter of spore in polar view excluding auriculae and sculpture 310-390 $\mu \mathrm{m}$ (25 specimens). Laesurae extend to equator of body, bordered by lips c. $10 \mu \mathrm{m}$ wide which extend into appendages up to $100 \mu \mathrm{m}$ long and $10 \mu \mathrm{m}$ in width, with pointed, bluntly rounded or expanded but flattened tips; amount of expansion up to 4 times width of process at mid-point of length. Adjacent to flange are one or two irregular rows of appendages of similar length to those on triradiate flange, but they are rounded rather than flattened in outline, and have rounded to pointed tips. Equator of spore is surrounded by a zona up to 25 $\mu \mathrm{m}$ wide interradially; this expands into auriculae in equatorial radial regions $c$. 70-120 $\mu \mathrm{m}$ wide and extending up to $100 \mu \mathrm{m}$ away from spore body where they merge with ends of triradiate flange.

Sculpture comprises small, closely spaced, irregularly granular to murornate elements of varying length but of generally uniform height (up to $10 \mu \mathrm{m}$ ), giving surface a roughened, sugary appearance at low magnifications. On zona, sculptural elements are aligned normal to surface of spore body, giving it a finely ribbed appearance.

Cross-sections of broken specimens show exoexine to be $c \cdot 10-15 \mu \mathrm{m}$ thick and composed of a three dimensional network of sporopollenin threads, the predominant orientation of which is subparallel to inner surface of wall. Alignment of sporopollenin threads is also evident on zona, triradiate flange and appendages, where they are mainly parallel to surface of these features. Exoexine is underlain by a thin $(c .1 \mu \mathrm{m})$ intexine, most of which also consists of a reticulate meshwork of sporopollenin threads similarly orientated mainly subparallel to surface of spore body; inner surface of this layer is, however, a thin, homogeneous membrane.

Derivation of name:

After EBK's daughter, Kristine Koppelhus

Holotype:
PI. 21, fig. 8; slide $\mathrm{HGHol} / 3$, Borehole 246.207, $26.00 \mathrm{~m}$, Robbedale Formation, upper Berriasian

Remarks:

At least some of the specimens of this species were recorded by Gry (1969) as Thomsonia (now Paxillitriletes) cf. pseudotenella Dijkstra, 1951. This resembles $P$. kristinae in having a triradiate flange that bears long appendages which may splay out at their tips. It is, however, sculptured with cones and spines (Mädler, 1954; Batten, 1969) and has a proportionally smaller body. A reworked specimen of Paxillitriletes in a Tertiary deposit recorded by Collinson et al. (1985, fig. 4f) as $P$. sp. nov. is similar, but the undivided triradiate flange is higher and the appendages extending from it are proportionally shorter.

Paxillitriletes vittatus Kovach \& Dilcher, 1985 has a similar wall structure (see for example, Kovach \& Dilcher, 1985, pl. 1, figs 5-8; Kovach \& Dilcher, 1988, pl. 4, figs 6,8 ).

Occurrence on Bornholm:

Rabekke and Robbedale Formations (Purbeck beds)

${ }^{*}$ Paxillitriletes phyllicus (Murray, 1939) Hall \& Nicolson, 1973

1939 Triletes phyllicus Murray, p. 482, figs 7,8

1973 Paxillitriletes phyllicus (Murray, 1939) Hall \& Nicolson, p. 320

Pl. 16, figs 2-4; Pl. 21, figs 9,13

Remarks:

$P$. phyllicus is a comparatively small megaspore with a prominent triradiate membraneous flange up to $100 \mu \mathrm{m}$ high (according to Harris, 1961) that extends onto, and fuses with, an equatorial flange which is narrow interradially, but commonly expanded into small auriculae radially. The triradiate flange merges with these. It is regularly ribbed and may be somewhat sinuous but, unlike that in many species of Paxillitriletes, its outer margin is usually continuous. The equatorial flange is similarly constructed, but often with low muri of the surface reticulum extending onto it. The reticulum comprises ridges of varying height, mainly $<5 \mu \mathrm{m}$ on the proximal face away from the triradiate flange, but often somewhat more elevated on the distal face (10-20 $\mu \mathrm{m})$. In addition, some muri may be prolonged into spines. Spinose elements dominate the sculpture towards the triradiate flange, and may be partly fused with it. They are usually not as long as the height of the flange; often they are only $1 / 2$ to $2 / 3$ of this.

Occurrence on Bornholm:

Bagå Formation (Korsodde and Onsbæk, coal-bearing beds; Boderne beds; Sorthat beds; Bagå beds; Levka beds, coal-bearing succession; Levka beds, above coalbearing succession) 
"Paxillitriletes sp. cf. P. pseudotenellus (Dijkstra, 1951) Hall \& Nicolson, 1973

1951 Triletes pseudotenellus Dijkstra, p. 12, pl. 3, figs 9,10

1973 Paxillitriletes pseudotenellus (Dijkstra) Hall \& Nicolson, p. 320

Remarks:

The majority of the specimens from the "Purbeck beds" that Gry compared with Paxillitriletes pseudotenellus (recorded as Thomsonia cf. pseudotenella) are here considered to be $P$. kristinae. The remainder, including specimens noted to occur in the Levka beds, belong in other species. None looks sufficiently like $P$. pseudotenellus for it to be compared with that species.

Paxillitriletes rasmusii sp. nov.

PI. 18, figs 1-8; PI. 21, figs 12,18

Diagnosis:

Trilete megaspore, triangular in equatorial outline; maximum diameter $400-500 \mu \mathrm{m}$ ( 25 specimens). Laesurae bordered by a flange from which extend flattened appendages of varying shape up to $150 \mu \mathrm{m}$ high. At its extremities, flange merges with zona which is commonly expanded to form auriculae up to $200 \mu \mathrm{m}$ wide and extending up to $200 \mu \mathrm{m}$ from spore body. Proximal face finely reticulate, but with numerous spines up to $80 \mu \mathrm{m}$ high extending from junctions of muri on spore body. Reticulum extends onto zona but muri become lower and towards angles, mainly orientated normal to equator. Distal face similarly sculptured but spinose extensions of reticulum are shorter (up to $50 \mu \mathrm{m}$ ) and more bluntly rounded.

Exoexine comprises a meshwork of sporopollenin threads, the predominant orientation of which is subparallel to outer surface of spore body. Appendages and both triradiate and equatorial flanges are composed of similar threads aligned mainly parallel to surface of these features.

Derivation of name:

After EBK's son, Rasmus Koppelhus

Holotype:

PI. 21, fig. 18; slide $\mathrm{HGHol} / 4$, Borehole 246.307a, $5.60 \mathrm{~m}$, Skyttegård Member of the Rabekke Formation, lower Berriasian

Remarks:

Dijkstra (1951) described several species of Triletes, now referred to Paxillitriletes and one form of Membranisporites ( $M$. samarus), which is morphologically similar, but none is closely comparable to P. rasmusii. This also applies to the other species of Paxillitriletes and to the only other Membranisporites ( $M$. trifoliaceus) that have been described previously (see Batten \& Kovach, 1990 for names and bibliographic data).

Occurrence on Bornholm:
Rabekke and Robbedale Formations

Paxillitriletes sp. cf. P. reticulatus (Mädler, 1954) Hall \& Nicolson, 1973

1954 Thomsonia reticulata Mädler, p. 150, pl. 5, figs 14-19, 34

1973 Paxillitriletes reticulatus (Mädler, 1954) Hall \& Nicolson, p. 319

Pl. 16, figs 5-7; Pl. 17, figs 1-3; Pl. 21, fig. 14

Description:

Megaspore, trilete; mean maximum diameter of spore in polar view excluding auriculae and sculpture $220-300$ $\mu \mathrm{m}$ (25 specimens). Laesurae extend to equator of body, bordered by ribbed lips c. 20-30 $\mu \mathrm{m}$ wide and up to $80 \mu \mathrm{m}$ high. Muri of reticulum of proximal face raised up into membraneous extensions that increase in elevation to approximately same height as triradiate flange. Equator of spore surrounded by a zona $c .10 \mu \mathrm{m}$ wide interradially; in equatorial radial regions this expands into auriculae $c .20-30 \mu \mathrm{m}$ wide and extending up to $50 \mu \mathrm{m}$ away from spore body where they merge with ends of triradiate flange.

Sculpture on both proximal and distal faces is a clearly defined reticulum; muri 1-2 $\mu \mathrm{m}$ wide and up to $5 \mu \mathrm{m}$ high, surrounding lumina of varying shape, up to $15 \mu \mathrm{m}$ in diameter; on zona, muri are aligned normal to surface of spore body, giving it a ribbed appearance.

Cross-sections of broken specimens show exine to be made up of spongy exoexine up to $10 \mu \mathrm{m}$ thick, composed of a three dimensional network of sporopollenin threads, the predominant orientation of which is subparallel to inner surface of wall. Alignment of sporopollenin threads is also evident on zona, triradiate flange and appendages, where they are mainly parallel to surface of these features. Exocxine is underlain by a thin $(1 \mu \mathrm{m})$ intexine, most of which also consists of a reticulate meshwork of sporopollenin threads similarly orientated mainly parallel to the surface of the spore body; inner surface of this layer is, however, a thin, homogeneous membrane.

Remarks:

Gry appears to have recorded this species, perhaps along with others, as Thomsonia (now Paxillitriletes) reticulata. However, P. reticulatus (Mädler, 1954) Hall \& Nicolson, 1973, the type species of the genus, was diagnosed as having "pilose sculpture along the tetrad rays or only in their immediate vicinity" (freely translated from Mädler, op. cit., p. 150); for scanning electron micrographs showing this character, see Pelzer \& Reigel, 1982, pl. 1, fig. 7 (recorded as P. cf. reticulatus) and Schultz \& Noll, 1987, pl. 7, fig. 6). The specimens shown here are not, however, sculptured in this way. $P$. fairlightensis Batten, 1969 is similar, and $P$. lindstroemi Huckreide, 1982 bears some resemblance to Gry's specimens, but again the triradiate flanges of both are 
bordered by discrete appendages rather than by membraneous muri.

Following his diagnosis of Triletes gryensis, Dijkstra (1961, p. 12) reported that "Dr Gry, during his visit to Heerlen, told us that he had found the same species in the Lower Wealden of Bornholm". It has not, howev$\mathrm{er}$, been easy to determine which form Gry was meaning. One of those it most closely resembles is $P$. sp. cf. $P$. reticulatus, but for several reasons we do not think it is the same. The single specimen figured by Dijkstra (1961, pl. 1, fig. 14) looks different from topotype material we have examined; his description of the species does not entirely fit with the characters we have observed; and the specimens in Gry's collection that are closest morphologically to $T$. gryensis are better preserved.

Occurrence on Bornholm:

Rabekke and Robbedale Formations (Purbeck beds)

Paxillitriletes spp. 1-3

Pl. 17, figs 4-8; Pl. 21, figs 10, 11

\section{Remarks:}

Paxillitriletes sp. 1 bears some resemblance to P. reticulatus but the sculpture is more spinose, and the muri of the reticulum do not form elevated membraneous extensions adjacent to the triradiate flange (Pl. 17, fig. 4). $P$. sp. 2 is distinct in having a rugulate wall (Pl. 17, figs $5,7)$ and $P$. sp. 3 has a roughened/scabrate surface (Pl. 17 , fig. 8), its uneven nature probably having been enhanced in most cases by the processes of degradation. It is typically triangular in shape with comparatively wide, flattened, finger-like processes extending upwards from the triradiate flange. In quite a few specimens a ridge runs parallel to the flange, and this may continue subequatorially adjacent to the inner part of the zona. In this respect it resembles Sepisporites annulatus Li \& Batten 1987, but it differs from this species in other ways.

Occurrence on Bornholm:

Bagå Formation; Rabekke and Robbedale Formations

STRIATRILETES van der Hammen, 1955 ex Potonié, 1956

*Striatriletes sulcatus (Dijkstra, 1951) Potonié, 1956

1951 Triletes sulcatus Dijkstra, p. 11, pl. 2, fig. 3

1956 Striatriletes sulcatus (Dijkstra) Potonié, p. 42

Pl. 17, fig. 9; Pl. 21, fig. 16

Remarks:

Of the morphological characters of the specimens referred to this species, the most significant is that the muri on the contact areas are radially orientated and extend onto the distal face, thus conforming with the characters of the type material.
Occurrence on Bornholm:

Rabekke and Robbedale Formations (Purbeck beds)

TRILEITES Erdtman, 1945 ex Potonié, 1956

* Trileites candoris Marcinkiewicz, 1960

1960 Trileites candoris Marcinkiewicz, p. 717, pl. 1, fig. 6

Pl. 19, figs 1-3; Pl. 21, fig. 15

\section{Description:}

The very few specimens of this species in Gry's collection are mostly broken or occur only as fragments. All are large, ranging from $c$. $750-1150 \mu \mathrm{m}$ in diameter, and have clearly delineated to prominent triradiate ridges $10-40 \mu \mathrm{m}$ high and $10-20 \mu \mathrm{m}$ in basal width. These extend to about $1 / 2$ the radius of the spore and are connected at their extremities by equally prominent, slightly sinuous curvaturae of similar dimensions.

The exine of fragmentary remains is seen to consist of a very thick (c. $40 \mu \mathrm{m}$; Harris, 1961: 20 to more than $50 \mu \mathrm{m}$; Kempf, 1972) exoexinal layer beneath which is a much thinner $(<1$ to $2 \mu \mathrm{m})$ membraneous intexine. Kempf (1972) has demonstrated that the exoexine consists of three layers.

\section{Remarks:}

T. candoris was erected by Marcinkiewicz (1960) on the basis of a single, laterally compressed specimen somewhat elongated about the polar axis and $800 \mu \mathrm{m}$ in diameter. The other characters noted were that the surface of the spore is smooth and glossy, and both the triradiate ridges and curvaturae are well developed, the latter being about $20 \mu \mathrm{m}$ in width and wavy in form.

On the basis of about 30 specimens from the Middle Jurassic of Yorkshire, Harris (1961) described more comprehensively very similar forms which he named Triletes turbanaeformis. This was later considered to be a junior synonym of $T$. candoris on the basis of priority of publication (Marcinkicwicz, 1981, p. 82).

Margaritatisporites regalis Marcinkiewicz 1962 is very similar, if not identical to $T$. candoris. The original diagnosis (description) was also based on only one specimen of closely comparable size and appearance. According to Marcinkiewicz $(1962$, pp. 473,491$)$ the arcuate ridges are only faintly indicated, but the single photograph shows them to be well developed.

Occurrence on Bornholm:

Sose Bugt Member (Sosevig beds), ?Galgeløkke Member, Bagå Formation (Korsodde and Onsbæk, coalbearing beds; Boderne beds; Sorthat beds; Bagå beds; Levka beds, coal-bearing succession; Levka beds, above coal-bearing succession)

*Trileites murrayi (Harris, 1961) Marcinkiewicz, 1971

1961 Triletes murrayi Harris, pp. 64,66, figs 20A-F, 21A-B 
1971 Trileites murrayi (Harris) Marcinkiewicz, p. 31, pl.1, figs $6-8$

Pl. 19, fig. 4; Pl. 21, fig. 19

Remarks:

Gry's reference of the spores with the characters of this species to $T$. murray $i$ was invalid at the time of publication because he failed to formally transfer the species from Triletes to Trileites by giving details of the basionym as required by the ICBN. This was not done until two years later (Marcinkiewicz, 1971).

This smooth-walled species can vary enormously in size. Harris (1961) gives a range of $250-1400 \mu \mathrm{m}$, but regarded those smaller than $500 \mu \mathrm{m}$ in diameter as abortive. The triradiate ridge is typically short $(1 / 3$ spore radius), c. $60 \mu \mathrm{m}$ broad, $40 \mu \mathrm{m}$ high, and sharply delineated by marginal grooves $10-20 \mu \mathrm{m}$ broad. Contact areas are usually undifferentiated but may be suggested by low, poorly defined ridges. The exoexine is very thick $(30-50 \mu \mathrm{m})$, beneath which is a thin $(c .2 \mu \mathrm{m})$ intexine.

Occurrence on Bornholm:

Bagå Formation (Korsodde and Onsbæk, coal-bearing beds; Boderne beds; Bagå beds; Levka beds, above coal-bearing succession)

VERRUTRILETES van der Hammen, 1955 ex Potonié, 1956 emend. Binda \& Srivastava, 1968

*Verrutriletes franconicus Jung, 1960

1960 Verrutriletes franconicus Jung, pp. 137,138, pl. 36 , figs $12-20$
Pl. 19, figs 5-8; Pl. 21, fig. 17

\section{Remarks:}

The spores identified as $V$. franconicus are mostly subcircular in equatorial outline and comparatively small (c. $400 \mu \mathrm{m}$ in diameter), thin walled (c. 5-7 $\mu \mathrm{m}$ ), and weakly sculptured with grana, coni, small verrucae and/or rugulae up to $15 \mu \mathrm{m}$ in basal diameter and $10 \mu \mathrm{m}$ high. The larger sculptural elements are confined in most specimens to the contact areas. In reflected light the remainder of the surface of the spore usually has a roughened to granular appearance. The triradiate ridges are often fairly prominent (c. 15-25 $\mu \mathrm{m}$ in basal width and up to $40 \mu \mathrm{m}$ high) and usually connect with more weakly delineated subequatorial curvaturae.

The combination of a thin exine, a comparatively subdued sculpture of coni and/or small verrucae usually restricted to proximal interradial regions, and relatively prominent triradiate ridges which merge with curvaturae serve to distinguish this species from most of the other spore-types that are attributable to Verrutriletes. Jung (1960) compared the species to Hughesisporites ionthus (Harris, 1935) Potonié, 1956, but concluded that, despite a superficial resemblance, there are significant differences in morphology.

The specimen of $V$. franconicus figured by Bertelsen \& Michelsen (1970) has a slightly sinuous triradiate ridge and more clearly delineated low verrucae on the contact areas. It also lacks curvaturae, and is larger than the Gry's specimens, most of which are only just over $200 \mu \mathrm{m}$ in maximum diameter.

Occurrence on Bornholm:

Munkerup Member (Munkerup clay), Sose Bugt Member (Sosevig beds, Vellengsby clay) 


\section{Affinities}

A recent increase in the number of systematic studies on the megaspores of extant plant species in which use has been made of scanning and transmission electron microscopy has helped to put morphological analyses of their fossil predecessors into botanical perspective. Particularly important for classifying both modern and fossil forms is the structure of their walls. Although we have not yet attempted any transmission electron microscopy of Gry's material we have, where possible, examined cross-sections under the SEM using broken specimens and fragments.

It is clear, both from our study and by comparison with observations made previously by ourselves and others in the literature, that most, if not all of the megaspores in Gry's collection are probably referable to the heterosporous lycopod orders Selaginellales and Isoetales. Although positive evidence of affinity for some is lacking, none appears to be the product of water ferns.

It is possible to divide the collection into four groups as follows:

1. Affinity unknown because there are no data (published or unpublished) on the structure of the their walls: Aneuletes patera; Verrutriletes franconicus. (As noted in the systematic section, A. discus is unlikely to be a megaspore.)

2. Affinity uncertain because although information about wall structure is available (e.g. in Hueber, 1982; Waksmundzka, 1986; Batten \& Ferguson, 1987, and herein), both this and the gross morphol- ogy of the spores are not closely comparable with the characters of any modern forms, and they have not been found in situ in remains of fossil plants: Cabochonicus carbunculus; Echitriletes; Hughesisporites.

3. Affinity probably lies with the Isoetales because the structure of the exine closely resembles that of the acid-resistant part of the wall of modern representatives of this order (cf. sections in, for example, Pettitt, 1966; Batten, 1988, Kovach \& Dilcher, 1988; Archangelsky \& Villar de Seoane, 1990; this paper): all of the species of Henrisporites, Minerisporites and Paxillitriletes.

4. Affinity probably lies with the Selaginellales because the structure of the wall is more compact, and in most species the exoexine is thicker than is usually the case for isoetalean products (cf. sections in, for example, Kempf, 1970, 1972; Bergad, 1978; Minaki, 1985; Batten, 1988; Taylor \& Taylor, 1988; Koppelhus \& Batten, 1989; Morbelli, 1990; this paper): all of the species of Bacutriletes, Erlansonisporites, Horstisporites, Maexisporites, Nathorstisporites, Striatriletes and Trileites.

Only one taxon in Gry's collection is reliably attributable to a particular fossil plant species. This is Nathorstisporites hopliticus, which has been closely linked to the heterosporous lycopod Lycostrobus scottii by a number of authors (e.g. Harris, 1926, 1935, 1946; Reissinger, 1952; Lundblad, 1956; Jung, 1958, 1960). 


\section{Stratigraphic value}

Gry (1969) showed that megaspores are of value for the stratigraphic subdivision and correlation of the Jurassic (and earliest Cretaceous) rocks on Bornholm, as is evident from the taxonomic associations listed in the section on material and methods above. Our reassessment of his assemblages in the light of an examination of selected specimens under the SEM and a larger body of literature than was available in 1969 has shown that his general conclusions on the ages of the associations he recognised are still valid except for those of the "Purbeck beds".

Among the age data plotted on Figure 5 are the maximum ranges for the previously published taxa recorded from the succession. Comparison of these with Gry's records of occurrences noted above show that the associations recorded for the different formations are consistent with them. Some of the taxa, such as Erlansonisporites sparassis, Horstisporites harrisii, Maexisporites soldanellus and Trileites murrayi, are relatively long-ranging, even allowing for possible misidentifications on which these plots are based (taken from Kovach \& Batten 1989, slightly modified). Others, such as Aneuletes patera, Bacutriletes corynactis, Echitriletes lanatus, Minerisporites volucris and Verrutriletes francon- icus have more restricted stratigraphic distributions and hence may serve as local "markers" for certain parts of the column. However, even those that have less restricted ranges can be important in the context of first and last appearances and associations with other taxa, such as Horstisporites areolatus and Nathorstisporites hopliticus.

Some of Gry's identifications have been questioned, required emendation and/or been nomenclaturally updated, as indicated in both the introductory discussion and from our handling of the taxa described in the systematic section of this paper. Those forms placed in comparison with other published species cannot be identified more positively until larger assemblages of newly acquired samples are analysed. Some previously undescribed species are present in his slides for which textual and photographic documentation is provided here. A few other species still require comprehensive analysis. This cannot be done until more and/or better preserved specimens have been obtained.

It is anticipated that this will be accomplished in a subsequent paper using new material which we hope will also enable us to give greater precision to some of the ranges of the species within the Bornholm succes-

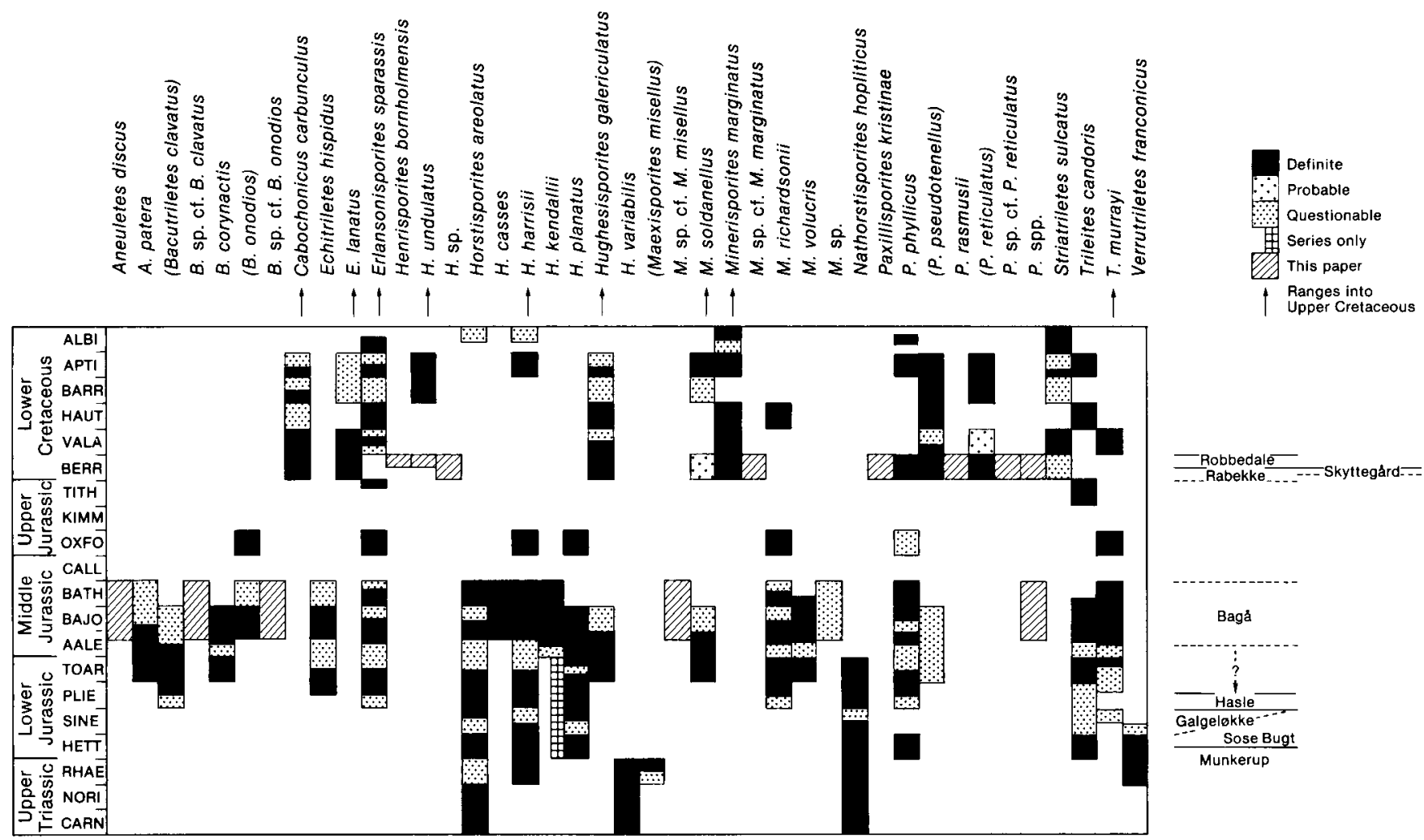

Fig. 5. Known ranges within Upper Triassic and younger mesozoic deposits of previously described species encountered in Gry's collection (adapted and slightly modified from Kovach \& Batten, 1989) plotted alongside stratigraphic occurrences of the taxa placed in comparison and the new species. 
sion. Unfortunately, the levels from which many of the assemblages in Gry's collection have come are not precisely located stratigraphically; indeed only very basic information is available for the majority. Our analysis has shown the need to resample the outcrops and any borehole sections that are currently accessible in order to clarify the ranges of the taxa in the light of current interpretations of age and the stratigraphic development of the succession. Hence the ranges of the new species and those taxa that are placed in comparison with previously published species are generalised to the maximum age-ranges of the formations concerned, pending further biostratigraphic analysis. 


\section{Acknowledgments}

The research for this paper was carried out while EBK was in receipt of Carlsberg Foundation Grants 88$0207 / 20$ and $90-0332 / 20$. Her work in Wales was supported by a travel and maintenance award from the Danish Research Academy. The Geological Survey of Denmark (DGU) is thanked for allowing us access to Gry's megaspore collection and for providing research facilities. We are grateful to Peter Moors and Benny
Schark (both DGU), and Geraint Hughes and David Griffiths (both University of Wales, Aberystwyth) for developing and printing our films, and to Annabeth Andersen (DGU) for drafting the figures. Prof. F. Surlyk (Copenhagen University), S. Piasecki (Geological Survey of Greenland) and L.H. Nielsen (DGU) are thanked for critically reading the manuscript. 
Allen, P. \& Wimbledon, W.A., 1991: Correlation of NW European Purbeck-Wealden (nonmarine Lower Cretaceous) as seen from the English type-areas. Cretaceous Research, 12(5), 511-526.

Archangelsky, S. \& Villar de Seoane, L., 1989: Ultraestructura de dos nuevas megasporas Cretacicas de Santa Cruz, Argentina. Boletín Asociación Latinoamericana Paleobotánica y Palynología, 12, 13-24.

Archangelsky, S. \& Villar de Seoane, L., 1990: Morfologia y estructura de megasporas Cretacicas de Patagonia, Republica Argentina Revista Española de Micropaleontología, 22, 419-450.

Arndorff, L., 1991: Paleosols as environmental indicators: an example from the Lower Jurassic Rønne Formation on the Island of Bornholm, Denmark. Abstracts, International Association of Sedimentologists, 12th Regional Meeting, Bergen, p.4.

Banerji. J., Jana, B.N. \& Maheshwari, H.K., 1984: The fossil floras of Kachchh. II. - Mesozoic megaspores. The Palaeobotanist, 33, 190-227

Batten, D.J., 1969: Some British Wealden megaspores and their facies distribution. Palaeontology, 12, 333-350, 6pl.

Batten, D.J., 1975: Wealden palaeoecology from the distribution of plant fossils. Proceedings of the Geologists' Association, 85 (for 1974), 433-458, $1 \mathrm{pl}$.

Batten, D.J., 1988: Revision of S.J.Dijkstra's Late Cretaceous megaspores and other plant microfossils from Limburg, The Netherlands. Mededelingen Rijks Geologische Dienst, 41-3, 55pp.

Batten, D.J. \& Ferguson, D.J.P., 1987: Cabochonicus, a new genus for species of gemmate megaspores previously referred to Verrutriletes. Journal of Micropalaeontology, 6(1), 65-75.

Batten, D.J. \& Kovach, W.L., 1990: Catalog of Mesozoic and Tertiary megaspores. American Association of Stratigraphic Palynologists, Contributions Series, 24 , ii $+227 \mathrm{pp}$.

Bergad. R.D., 1978: Ultrastructural studies of selected North American Cretaceous megaspores of Minerisporites, Erlansonisporites, Horstisporites, and Ricinospora, n. gen. Palynology, 2, 39-51.

Bertclsen, F. \& Michelsen, O., 1970: Megaspores and ostracods from the Rhaeto-Liassic section in the boring Rødby No. 1, southern Denmark. Danmarks Geologiske Undersøgelse, II rk., 94, 60pp., $17 \mathrm{pl}$.

Binda, P.L. \& Srivastava, S.K., 1968: Silicified megaspores from Upper Cretaceous beds of southern Alberta, Canada. Micropaleontology, 14, 105-113.

Candilier, A.M., Coquel, R. \& Decommer, H., 1982: Étude palynologique du Lias dans le Boulonnais (Nord de la France). Revue de Micropaléontologie, 25, 17-25.

Casey, R., 1973: The ammonite succession at the Jurassic-Cretaceous boundary in eastern England. In: Casey, R. \& Rawson, P.F. (eds): The Boreal Lower Cretaceous. Geological Journal Special Issue 5 , $193-266$

Christensen, O.B., 1963: Ostracods from the Purbeck-Wealden beds in Bornholm. Danmarks Geologiske Undersøgelse, II rk., 86, $58 \mathrm{pp} ., 5 \mathrm{pl}$

Christensen, O.B., 1966: Om purbeckien aflejringerne $\mathrm{i}$ det nedsænkede område ved Salene Bugt, Bornholm. Meddedelser fra Dansk Geologiske Forening, København, 16, 465-466, 1 pl.

Christensen, O.B.. 1974: Marine communications through the Danish Embayment during uppermost Jurassic and lowermost Cretaceous. Geoscience and Man, 6, 99-115, 1pl.

Collinson, M.E., Batten, D.J., Scott, A.C. \& Ayonghe, S.N., 1985: Palaeozoic, Mesozoic and contemporaneous megaspores from the Tertiary of southern England: indicators of sedimentary provenance and ancient vegetation. Journal of the Geological Society, London, 142, 375-395.

Danzé, J. \& Laveine, J.P., 1963: Étude palynologique d'une argile provenant de la limite Lias-Dogger, dans un sondage à Boulognesur-Mer. Annales de la Société Géologique du Nord, 83, 79-90, $4 \mathrm{pl}$.
Delcourt, A. \& Sprumont, G., 1955: Les spores et grains de pollen du Wealdien du Hainaut. Mémoire de la Société Belge de Géologie, de Paléontologie et d'Hydrologie, nouvelle séric, 4(5), 73pp, $4 \mathrm{pl}$

Dettmann, M.E., 1961: Lower Mesozoic megaspores from Tasmania and South Australia. Micropaleontology, 7, 71-86.

Dijkstra, S.J., 1949: Megaspores and some other fossils from the Aachenian (Senonian) in south Limburg, Netherlands. Mededelingen van de Geologische Stichting, Nieuwe Serie, 3, 19-32, 2pl.

Dijkstra, S.J., 1951: Wealden megaspores and their stratigraphical value. Mededelingen van de Geologische Stichting, Nieuwe Serie, $5,7-22,2 \mathrm{pl}$.

Dijkstra, S.J., 1961: On megaspores, Charophyta fruits and some other small fossils from the Cretaceous. The Palaeobotanist, 8 (for 1959), 8-18, 2pl.

Dörhöfer, G. \& Norris, G., 1977: Palynostratigraphische Beiträge zur Korrelierung jurassisch-kretazischer Grenzschichten in Deutschland und England. Neues Jahrbuch für Geologie und Paläontologie, Abhandlungen, 153, 50-69.

Dybkjær, K., 1991: Palynological zonation and palynofacies investigation of the Fjerritslev Formation (Lower Jurassic - basal Middle Jurassic) in the Danish Subbasin. Danmarks Geologiske Undersøgelse, Serie A, 30, 150pp., 6 tables.

Floquet, M. \& Lachkar, G., 1979: Précisions stratigraphiques, paléogéographiques et premières descriptions de mégaspores dans le Cénomanien supérieur en Espagne du Nord. Revue de Micropaléontologie, 22, 134-155.

Fuglewicz, R., 1973: Megaspores of Polish Buntersandstein and their stratigraphical significance. Acta Palaeontologica Polonica, 18, $401-453,14 \mathrm{pl}$.

Gamerro, J.C., 1975: Megasporas del Cretacico de Patagonia II. Megasporas petrificadas de la Formacion La Amarga, Cretacico Inferior, Prov. Neuquén. Actas I Congreso Argentino de Paleontologia y Bioestratigrafia, Tucuman, 1974, 2, 11-28.

Gamerro, J.C., 1977: Megasporas del Cretacico de Patagonia III. Megasporas petrificadas del "Chubutense", Prov. del Chubut, Argentina. Ameghiniana, 14, 100-116.

Gravesen, P., 1977: A/S Carl Nielsens sandgrav, Robbedale (lok. 39) and Arnager Bugt ( $\emptyset_{\text {st }}$ for Madsegrav) (lok. 40). Varv ekskursionsfører nr. 1, Geologi på Bornholm, 73-82.

Gravesen, P., 1982: Lower Cretaceous sedimentation and basin extension on Bornholm. Denmark. Danmarks Geologiske Undersøgelse, Årbog, 1981, 73-99.

Gravesen, P., Rolle, F. \& Surlyk, F., 1982: Lithostratigraphy and sedimentary evolution of the Triassic, Jurassic and Lower Cretaceous of Bornholm, Denmark. Danmarks Geologiske Undersøgelse, Serie B, 7, 51pp.

Grönwall, K.A. \& Milthers, V., 1916: Kortbladet Bornholm. Danmarks Geologiske Unders $\varnothing$ gelse, I rk., 13, 281pp.

Gry, H., 1956: Wealdenaflejringerne på Bornholm deres stratigrafi og tektonik. Meddelelser fra Dansk Geologiske Forening, 13, 134 141.

Gry, H.. 1960: Geology of Bornholm. Guide to excursions nos A45 and C40. International Geological Congress, 21st Session, Norden, $16 \mathrm{pp}$

Gry, H., 1968: Callianassagange og Skolithosrør i Robbedaleformationen. Meddelelser fra Dansk Geologiske Forening, 18, 205-212.

Gry, H., 1969: Megaspores from the Jurassic of the island of Bornholm, Denmark. Meddelelser fra Dansk Geologiske Forening, 19, 69-89.

Hall, J.W. \& Nicolson, D.H., 1973: Paxillitriletes, a new name for fossil megaspores hitherto invalidly named Thomsonia. Taxon, 22, 319-320.

Haq, B.U., Hardenbol, J. \& Vail, P., 1988: Mesozoic and Cenozoic chronostratigraphy and cycles of sea level change. Society of Eco- 
nomic Palcontologists and Mineralogists, Special Publication, 42, $71-108$.

Harris, T.M., 1926: The Rhaetic flora of Scoresby Sound, East Greenland. Meddelelser om Grønland, 68, 43-147, 13pl.

Harris, T.M., 1935: The fossil flora of Scoresby Sound, East Greenland. Part 4: Ginkgoales, Coniferales, Lycopodiales and isolated fructifications. Mcddelelser om Grønland, 112(1), 176pp., $29 \mathrm{pl}$.

Harris, T.M., 1937: The fossil flora of Scoresby Sound, East Greenland. Part 5: Stratigraphic relations of the plant beds. Meddelelser om Gronland, 112(2), 114pp., 1pl.

Harris, I.M., 1946: Liassic and Rhatic plants collected in 1936-38 from East Greenland. Meddelelser om Grønland, 114(19), 39pp, $1 \mathrm{pl}$.

Harris, T.M., 1961: The Yorkshire Jurassic flora I. ThallophytaPteridophyta. British Museum (Natural History), London, ix + 212pp.

Herngreen, G.F.W., van Hoeken-Klinkenberg, P.M.J. \& de Boer, K.F., 1980: Some remarks on selected palynomorphs near the Jurassic-Cretaceous boundary in The Netherlands. Proceedings of the 4th International Palynological Conference, Lucknow, 1976-77, 2, 357-367, 2pl.

Hoelstad, T., 1985: Palynology of the uppermost Lower to Middle Jurassic strata on Bornholm, Denmark. Bulletin of the Geological Society of Denmark, 34, 111-132.

Hopkins, W.S. \& Sweet, A.R., 1976. Miospores and megaspores from the Lower Cretaceous Mattagami Formation of Ontario. Geological Survey of Canada, Bulletin, 256, 55-71.

Huckreide, R., 1967: Molluscenfauna mit limnischen und brackischen Elementen aus Jura, Serpulit und Wealden NW-Deutschlands und ihre palaeogeographische Bedeutung. Beihefte zum Geologischen Jahrbuch, 67, 263pp, 25pl.

Huckreide, R., 1982: Die unterkretazische Karsthöhlen-Füllung von Nehden im Sauerland. 1. Geologische, paläozoologische und paläobotanische Befunde und Datierung. Gcologica et Palacontologica, 16, 183-242.

Hueber, F.M., 1982: Megaspores and a palynomorph from the Lower Potomac Group in Virginia. Smithsonian Contributions to Paleobiology, 49, iii + 69pp.

Hughes, N.F., 1955: Wealden plant microfossils. Geological Magazine, $92,201-217,3 \mathrm{pl}$.

Hughes, N.F., 1958: Palaeontological evidence for the age of the English Wealden. Geological Magazine 95, 41-49.

Jensen, J.B. \& Hamann, N.E., 1989: Geological mapping of Mesozoic deposits along the eastern margin of the Rønne Graben, offshore Bornholm, Denmark. Bulletin of the Geological Socicty of Denmark. 37. 237-260.

Jung, W., 1958: Zur Biologie und Morphologie einiger disperser Megasporen, vergleichbar mit solchen von Lycostrobus scotti, aus dem Rhät-Lias Frankens. Geologische Blätter für NordostBayern, 8, 114-130, 1pl.

Jung. W., 1960: Die dispersen Megasporen der fränkischen RhätLias-Grenzschichten. Palacontographica B, 107, 127-170, 4pl.

Jux, U. \& Strauch, F., 1968: Ophiomorpha Lundgren 1891 aus dem Mesozoikum von Bornholm. Meddelelser fra Dansk Geologiske Forening, 18, 213-219, 1pl.

Kempf, E.K., 1970: Elektronenmikroskopie der Sporodermis von Megasporen der Gattung Selaginella (Pteridophyta). Review of Palacobotany and Palynology, 10, 99-116.

Kempf, E.K., 1972: Electron microscopy of Mesozoic megaspores from Denmark. Grana, 11 (for 1971), 151-163.

Kendall, M., 1942: Jurassic lycopod megaspores from the Gristhorpe plant bed. Annals and Magazine of Natural History, Series, 11, 9 , 920-923.

Koppelhus, E.B., 1991: Palynology of the Lower Jurassic Rønne Formation on Bornholm, eastern Denmark. Bulletin of the Geological Society of Denmark, 39, 1-20.

Koppelhus, E.B. \& Batten, D.J., 1989: Late Cretaceous megaspores from southern Sweden: morphology and palcoenvironmental significance. Palynology, 13, 91-120.

Kovach, W.L., 1988: Quantitative palaeoecology of megaspores and other dispersed plant remains from the Cenomanian of Kansas, USA. Cretaceous Research, 9, 265-283.

Kovach, W.L. \& Batten, D.J., 1989: World-wide stratigraphic occurrences of Mesozoic and Tertiary megaspores. Palynology, 13, 247277.

Kovach, W.L. \& Dilcher, D.L., 1985: Morphology, ultrastructure, and paleoecology of Paxillitriletes vittatus sp. nov. from the midCretaceous (Cenomanian) of Kansas. Palynology, 9, 85-94.

Kovach, W.L. \& Dilcher, D.L., 1988: Megaspores and other dispersed plant remains from the Dakota Formation (Cenomanian) of Kansas, U.S.A. Palynology, 12, 89-119.

Kozur, H., 1973: Neue Megasporen aus dem Karn des Ilek-Beckens. Geologische und Paläontologische Mitteilungen Innsbruck, 3 , $1-12,3 \mathrm{pl}$.

Li Wenben, Batten, D.J., Zhang Dahua \& Zhang Liangde, 1987: Early Cretaceous megaspores from the Jalainor Group of northcast Inner Mongolia, P.R. China. Palaeontographica B, 206, 117 $135,9 \mathrm{pl}$.

Lund, J.J., 1977: Rhaetic to Lower Jurassic palynology of the onshore south-eastern North Sea Basin. Danmarks Geologiske Undersøgelse, II Række, 109, 129pp.

Lundblad, A.B., 1956. On the stratigraphical value of the megaspores of Lycostrobus scotti. Sveriges Geologiska Undersökning, Series C (547), Årsbok, 50, 1-11, 1 pl.

Mädler, K., 1954: Azolla aus dem Quartär und Tertiär sowie ihre Bedeutung für die Taxionomie älterer Sporen. Geologisches Jahrbuch, 70, 143-157.

Marcinkiewicz, T., 1960: Analiza megasporowa osadów jurajskich okolic Gorzowa Śla̧skiego-Praszki. Kwartalnik Geologiczny, 4, 713-733, 8pl. (English and Russian summaries)

Marcinkiewicz, T, 1962: Megaspory retyku i liasu z wiercenia Mechowo koło Kamienia Pomorskiego i ich wartość stratygraficzna. Instytut Geologiczny, Prace, 30, 469-493, 13pl. (Russian and English summaries)

Marcinkiewicz, T., 1971: Stratygrafia retyku i liasu w Polsce na podstawie badań megasporowych. Instytut Geologiczny, Prace, 65, 58pp., 22pl. (Russian and English summaries)

Marcinkiewicz, T., 1978: Zespoły megasporowe w kajprze Polski. Prace Instytutu Geologicznego, 87, 61-84, 14pl. (Russian and English summaries)

Marcinkiewicz, T., 1980: Jurassic megaspores from Grojec near Kraków. Acta Palaeobotanica, 21, 37-60, 14pl.

Marcinkiewicz, T., 1981: Megaspory [Jura Dolna, Flora]. In: Malinowska, L., Bielecka, W. \& Rogalska, M. (cds): Budowa geologiczna Polski, Atlas skamienałości przewodnich i charakterystycznych, Mezozoik, Jura. Wydawnictwa Geologiczne, Warszawa, $3(2 \mathrm{~b}$; for 1980$), 79-97,6 \mathrm{pl}$.

Marcinkiewicz, T., 1983: Megaspores of the upper Muschelkalk from the Kościerzyna IG-1 Borehole (N.Poland). Acta Palaeobotanica, 23, 13-19, 9pl.

Marcinkiewicz, T., 1988: Megaspores [Lower Jurassic, Flora]. In: Malinowska, L. (ed.): Geology of Poland. Atlas of guide and characteristic fossils, Mesozoic, Jurassic. Wydawnictwa Geologiczne, Warsaw, 3(2b), 64-81.

Minaki, M., 1985: Macrospore morphology and taxonomy of Selaginella (Selaginellaceae). Pollen et Spores, 26 (for 1984), 421-479.

Miner, E.L., 1932: Megaspores ascribed to Selaginellites, from the Upper Cretaceous coals of western Greenland. Journal of the Washington Academy of Sciences, 22, 497-506.

Morbelli, M.A., 1990: Austral South American Jurassic megaspores. Review of Palaeobotany and Palynology, 65, 209-216.

Murray, N., 1939: The microflora of the Upper and Lower Estuarine Series of the East Midlands. Geological Magazine, 76, 478-489.

Nielsen, L.H. \& Koppelhus, E.B., 1991: Reworked Carboniferous palynomorphs from the Lower Jurassic of Bornholm and their palaeogeographic significance. Bulletin of the Geological Socicty of Denmark, 38, 253-266.

Noe-Nygaard, N. \& Surlyk, F., 1988: Washover fan and brackish bay sedimentation in the Berriasian-Valanginian of Bornholm, Denmark. Sedimentology, 35, 197-217.

Pelzer, G. \& Riegel, W., 1982: Megasporen aus der BückebergFormation 1 (Wealden) des Osterwaldes - cine vorläufige Mitteilung. Courier Forschungsinstitut Senckenberg, 56, 23-32.

Pelzer, G. \& Wilde, V., 1987: Klimatische Tendenzen während der Ablagerung der Wealden-Fazies in Nordwesteuropa. Geologisches Jahrbuch A, 96, 239-263.

Pettitt, J.M., 1966: Exine structure in some fossil and recent spores and pollen as revealed by light and electron microscopy. Bulletin of the British Museum (Natural History). Geology, 13, 221-257. $21 \mathrm{pl}$.

Piasecki, S., 1984: Dinoflagellate cyst stratigraphy of the Lower 
Cretaceous Jydegård Formation, Bornholm, Denmark. Bulletin of the Geological Society of Denmark, 32, 145-161.

Potonié, R., 1956: Synopsis der Gattungen der Sporae dispersae I. Teil: Sporites. Beihefte zum Geologischen Jahrbuch, 23, 103pp., $11 \mathrm{pl}$.

Reissinger, A., 1952: Über den Ursprung der Angiospermen. Naturwissenschaftliche Gesellschaft Bayreuth, 24pp., 4pl.

Rolle, F., 1978: Sedimentationsmiljøer i Nedre Jura på Bornholm. Unpublished thesis, University of Copenhagen, 85pp.

Sellwood, B.W., 1972: Tidal-flat sedimentation in the Lower Jurassic of Bornholm, Denmark. Palaeogeography, Palaeoclimatology, Palaeoecology, 11, 93-106

Schultz, G. \& Noll, H., 1987: Die Megasporen-assoziation in den unterkretazischen Sedimenten einer Paläokarsthöhle bei Nehden im Sauerland (Rheinisches Schiefergebirge). Palacontographica B, $203,83-107,7 \mathrm{pl}$

Surlyk, F., 1980: Denmark. In: Gcology of the European countries, Denmark, Finland, Iceland, Norway, Sweden. Dunod, published in cooperation with the Comité National Français de Géologie for the 26th International Geological Congress, 1-50.

Surlyk, F. \& Noe-Nygaard, N., 1986: Hummocky cross-stratification from the Lower Jurassic Hasle Formation of Bornholm, Denmark. Sedimentary Geology, 46, 259-273.

Surlyk, F. \& Noe-Nygaard, N., 1988: Alger og massedød for 140 millioner år siden. Naturens Verden 1988, 338-349.

Sweet, A.R., 1979: Jurassic and Cretaceous megaspores. American Association of Stratigraphic Palynologists, Contributions Series, 5B, 1-30.

Taylor, W.A. \& Taylor, T.N., 1988: Ultrastructural analysis of selected Cretaceous megaspores from Argentina. Journal of Micropalaeontology, 7(1), 73-87.

Tschudy, R.H., 1975: The megaspore genus Henrisporites from the Cretaceous of Massachusetts. Journal of Research of the United States Geological Survey, 3, 15-20.

Tyge, P., 1990: Palæotidale processer i en mundingsbarre association fra den Nedre Jurassiske Galgeløkke Member, Bornholm. Dansk Geologiske Forening, Årsskrift for 1987-1989, 37-40.

van der Hammen, T., 1955: Principios para la nomenclatura palinológica sistematica. Boletin Geologico, 2(2) (for 1954), 3-21.

Waksmundzka, M., 1986: Nature of ornamentation in megaspores of the genus Verrutriletes. Acta Palaeontologica Polonica, 30 (for 1985), 93-98, 4pl. 


\section{Appendix}

Boreholes referred to in the text and their geographical location:

244.83, Hasle Klinkerfabrik clay pit 244.105, Hasle Klinkerfabrik clay pit 244.232, Bakkegård 246.207, Robbedale
246.279, Nylars

246.307(a), Skyttegård

247.130, Eskegård

247.130(f), Eskegård

247.131(c), Eskegård

247.134, Hundshale/Saxebro 
PLATES 1-21 


\section{PLATE 1}

Figs 1-3, Aneuletes patera (from Anholt-4 borehole); all same specimen. 1, whole spore in proximal view, $\times 300.2$, close-up of part of presumed proximal face showing surface "swellings" (verrucate to rugulate elements), $\times 900$. 3 , proximal subequatorial surface showing granulate-rugulate wall, surface perforations, and granular to vermiform appearance of sporopollenin, $\times 9000$. Figs 4-7, Aneuletes discus (from borehole 244.105, Hasle Klinkerfabrik clay pit). 4, general view, $\times 150$. 5, close-up of rough, presumably at least partly degraded surface of same specimen; no distinctive sculpture, $\times 1000.6$, portion of brittle wall in cross-section of specimen illustrated in fig. 7 , showing homogeneous appearance and conchoidal fractures, $\times 2500.7$, section of whole specimen, $\times 400$. 

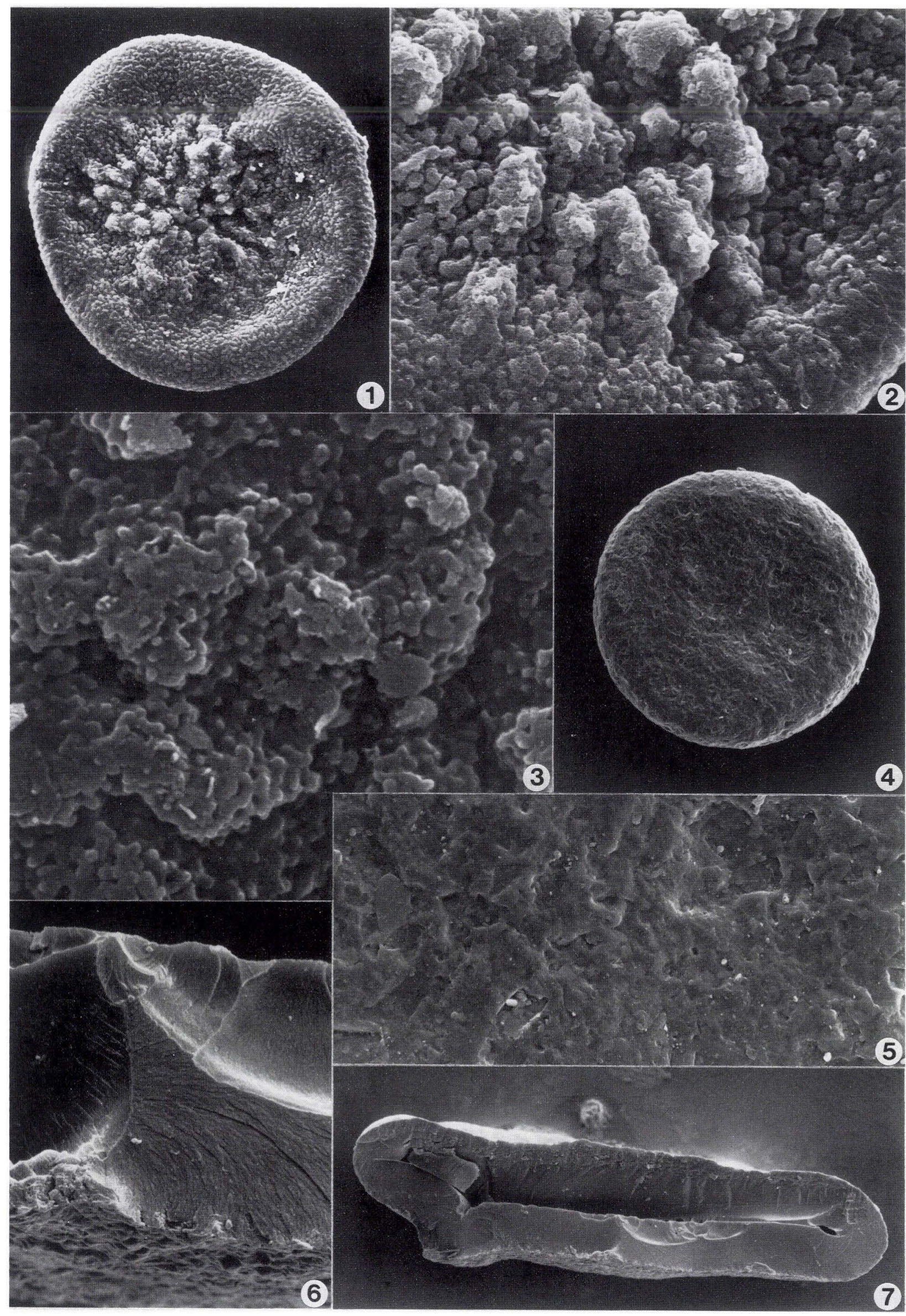


\section{PLATE 2}

Fig. 1, Aneuletes discus, section of wall, same specimen as shown on Pl. 1, fig. $7, \times 5000$.

Fig. 2, Aneuletes-like body (from Sose Bugt outcrop), $\times 150$.

Figs 3-5, Bacutriletes sp. cf. B. clavatus (from slide 13, Gry's collection, Hasle Klinkerfabrik clay pit); all same specimen. 3 , oblique view of whole spore, $\times 120$. 4 , close-up of part of proximal surface close to equator, $\times 5000.5$, close-up of triradiate ridge and adjacent proximal surface, $\times 500$.

Fig. 6, Bacutriletes sp. cf. B. onodios (from borehole 244.83, Hasle Klinkerfabrik clay pit), proximal view, $\times 200$ ). 


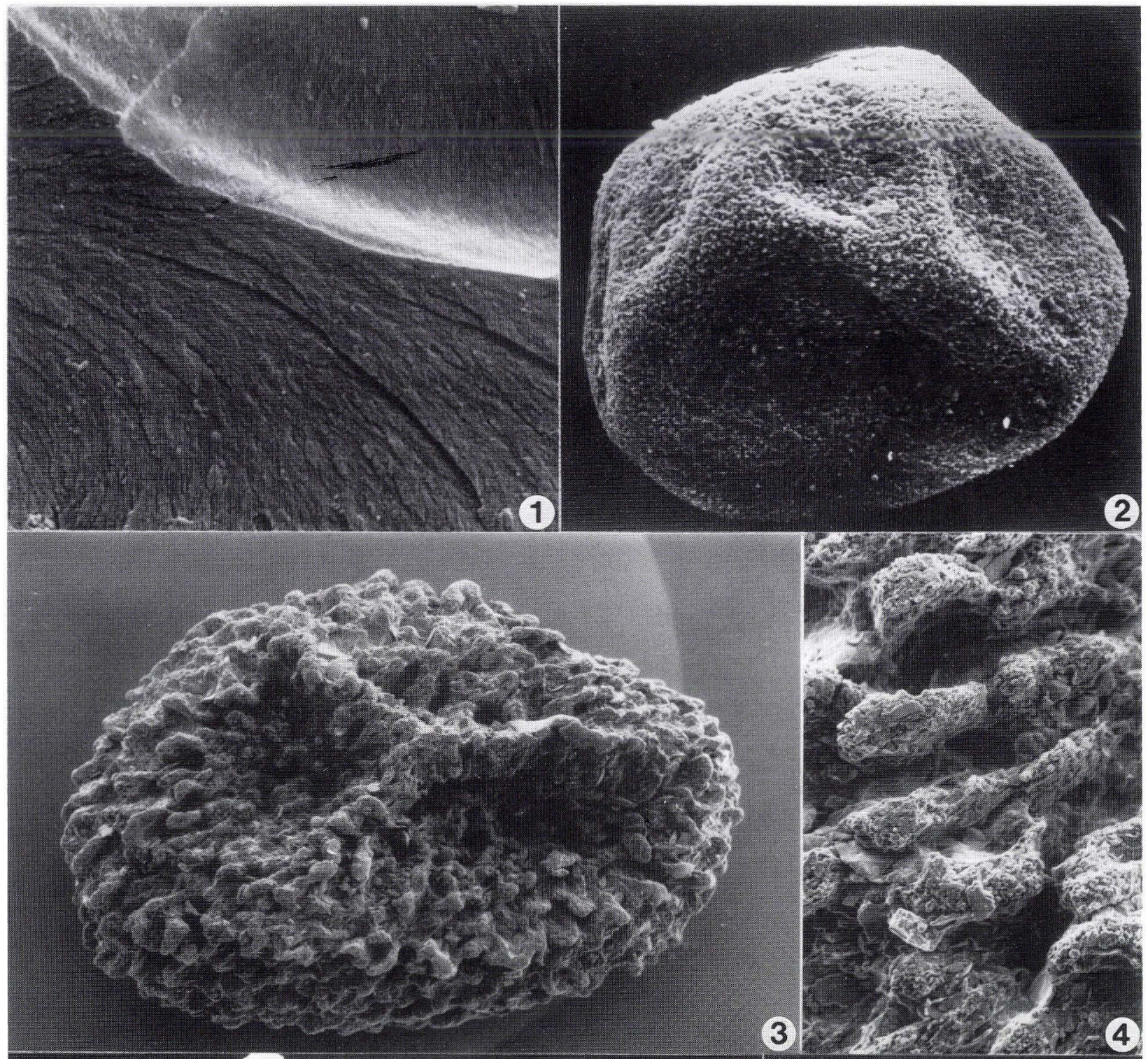

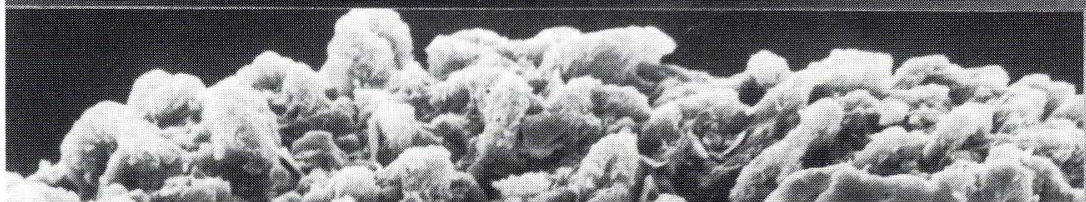

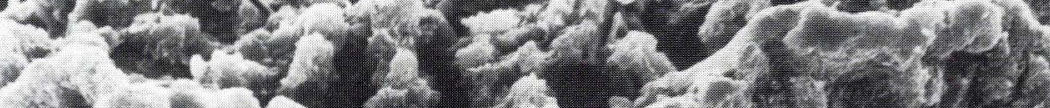
(2)

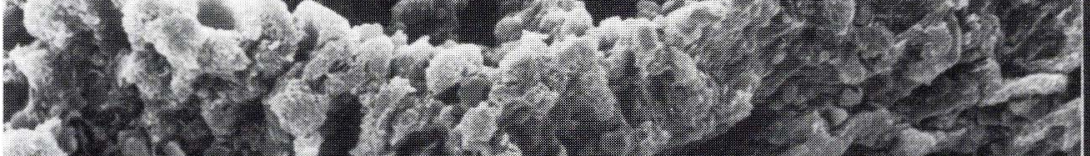
-

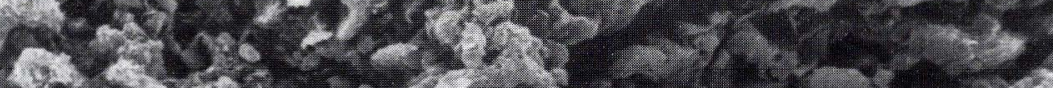

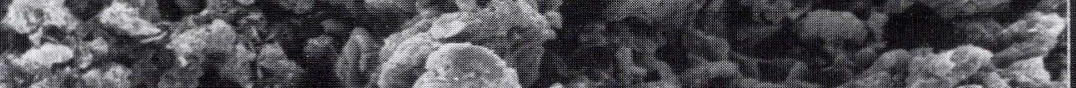

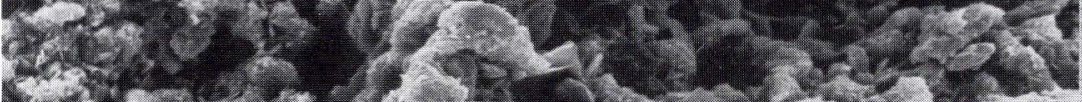

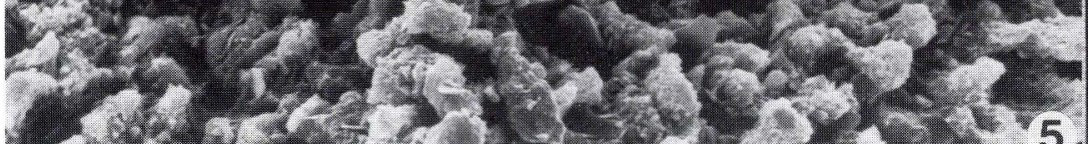

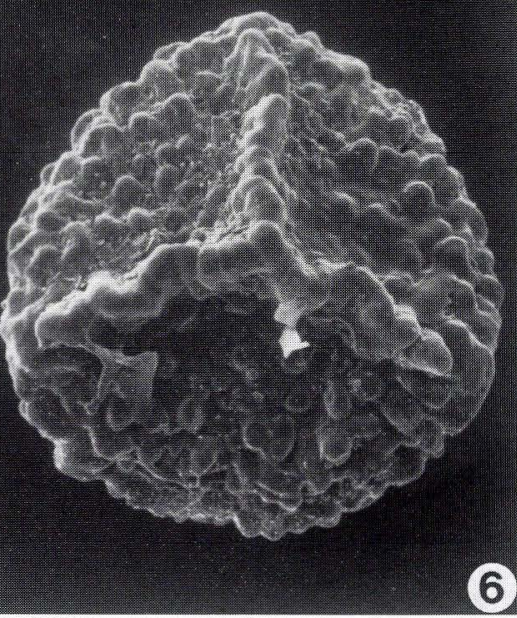




\section{PLATE 3}

Figs 1-5, Bacutriletes corynactis (from slide 15, Gry's collection, Hasle Klinkerfabrik clay pit). 1, whole specimen in lateral view, $\times 200.2$, broken specimen; portion of transverse section of exoexine and basal part of an appendage showing reticulate construction, $\times 5000.3$, section though broken appendage of specimen illustrated in fig. $1, \times 10000.4$, part of fractured wall of another specimen showing membraneous intexine beneath much thicker exoexine, $\times 1700$. 5 , close-up of some baculate-clavate appendages, same specimen as in figs 1 and 3, $\times 2500$.

Figs 6-8, Caboconicus carbunculus (from Skyttegård outcrop); all same specimen. 6, general view, $\times 125$. 7, detail of outer surface of exoexine, $\times 4000$. 8 , close-up of some of the pitted gemmae, $\times 1000$. 
Plate 3
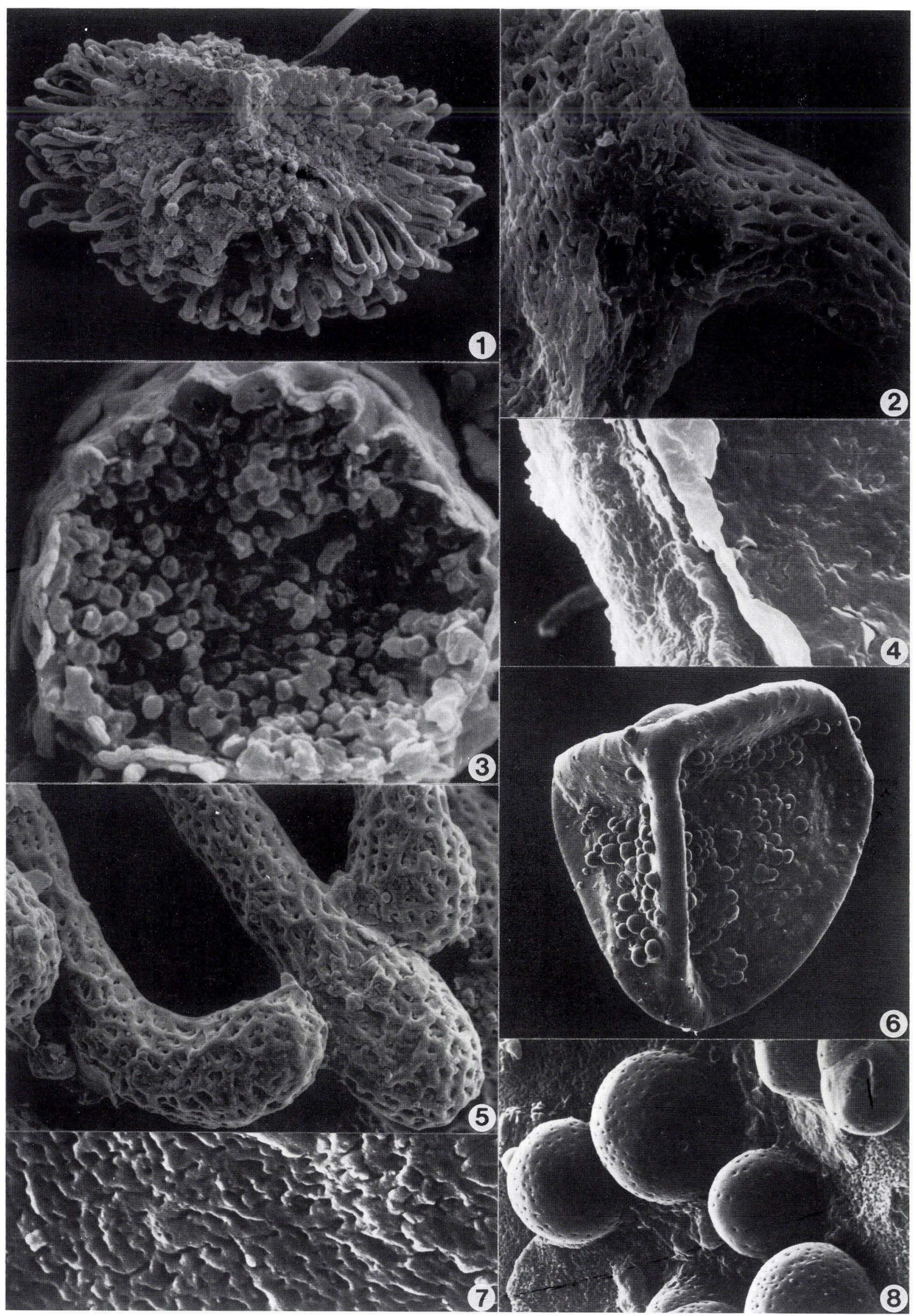
PLATE 4

Figs 1-5, Bacutriletes sp. cf. B. onodios. 1, oblique view of spore from borehole 246.279 , Nylars, $\times 200.2$, same specimen, detail of contact area and trilete ridge, $\times 400$. 3-5, broken specimen from borehole 246.279 , Nylars. 3, general view showing comparatively thin, membraneous intexine beneath much thicker exoexine, $\times 200$. 4 , close-up of proximal polar area, $\times 500$. 5 , section of part of proximal, rather dirty, spongy exoexine, $\times 2000$.

Figs 6-8, Echitriletes lanatus (from borehole 247.307a, Skyttegård). 6, 7, same specimen. 6, proximal view, $\times 170.7$, close-up of part of proximal face close to equator, $\times 500.8$, fragment of wall of another specimen (from borehole 247.134 between Hundshale and Saxebro) in cross-section showing inner portion of spongiose exoexine and intexine which has partly pulled away from it, $\times 3000$. 


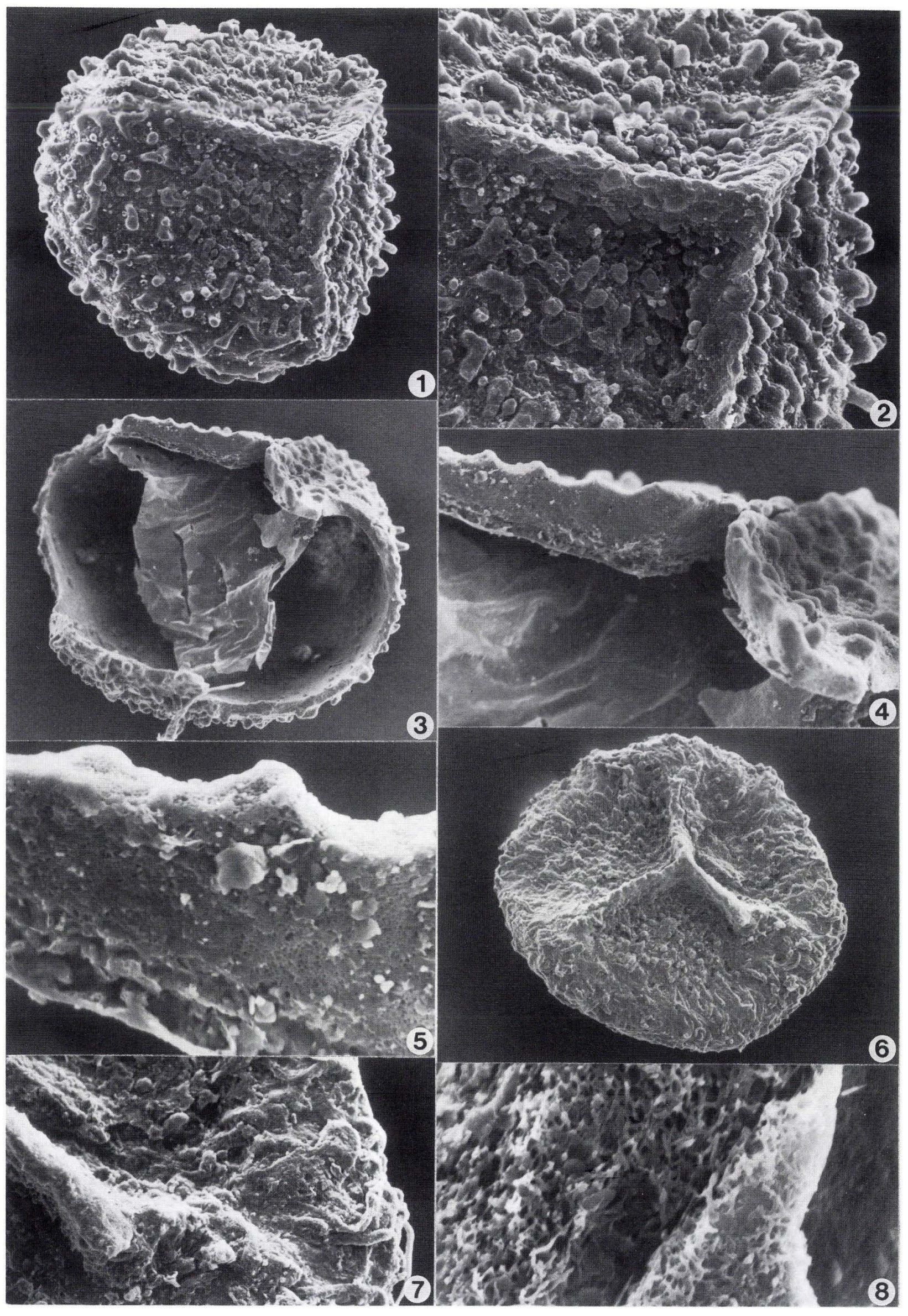




\section{PLATE 5}

Figs 1,2, Erlansonisporites sparassis. 1, close-up of reticulate sculpture of specimen from Homandshald outcrop shown in fig. 2 , with adhering inorganic particulate detritus, $\times 700.2$, proximal view, $\times 150$.

Figs 3, 4, Henrisporites undulatus. 3, oblique-lateral view of spore from borehole 246.207 , Robbedale, $\times 150$. 4, close-up of part of contact area of same specimen, $\times 500$.

Figs 5, 7, Henrisporites sp. from borehole 247.130f, Eskegård. 5, proximal view, $\times 160$. 7, same specimen, close-up of part proximal face and zona, $\times 450$.

Figs 6, 8, Henrisporites undulatus. 6, laterally compressed example from borehole 246.207, Robbedale, $\times 150$. 8, same specimen, detail of surface of exoexine showing reticulate construction, $\times 6000$. 

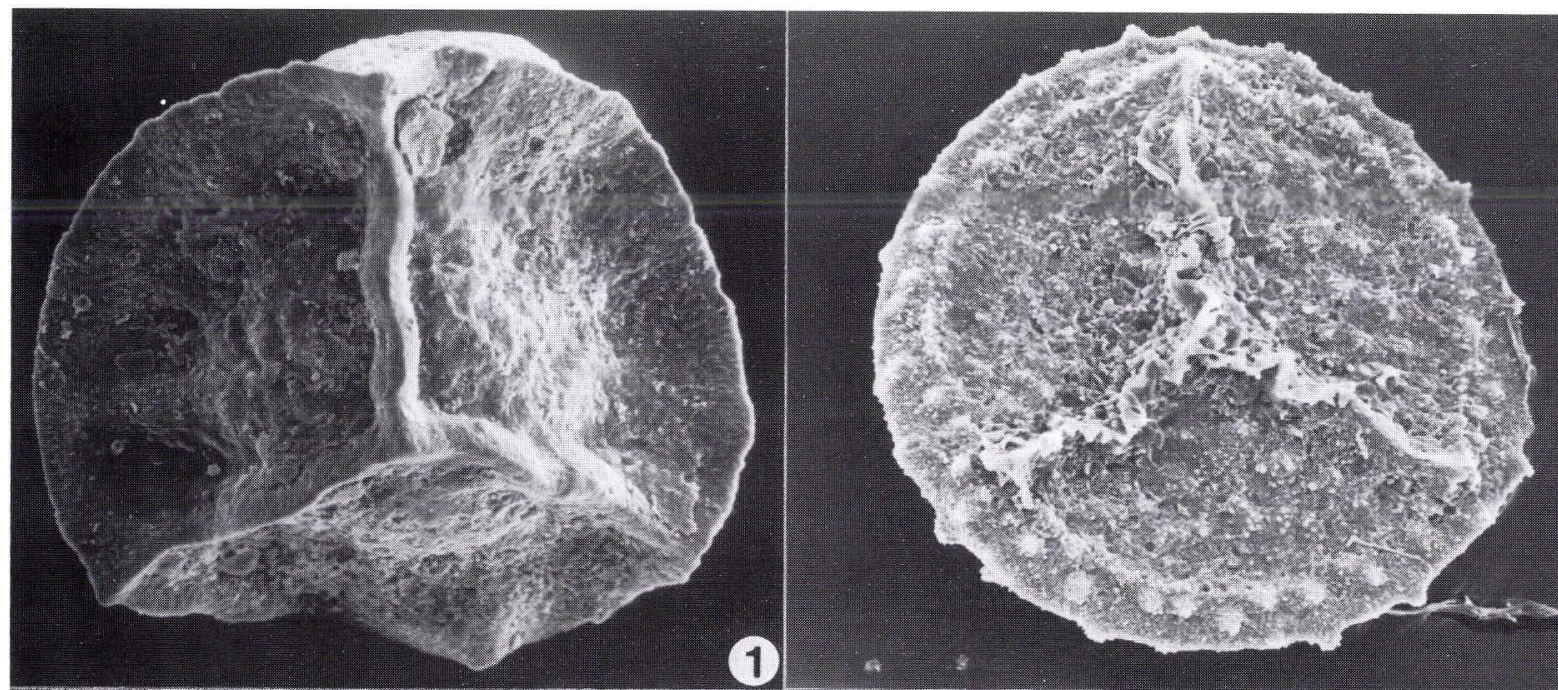

(2)
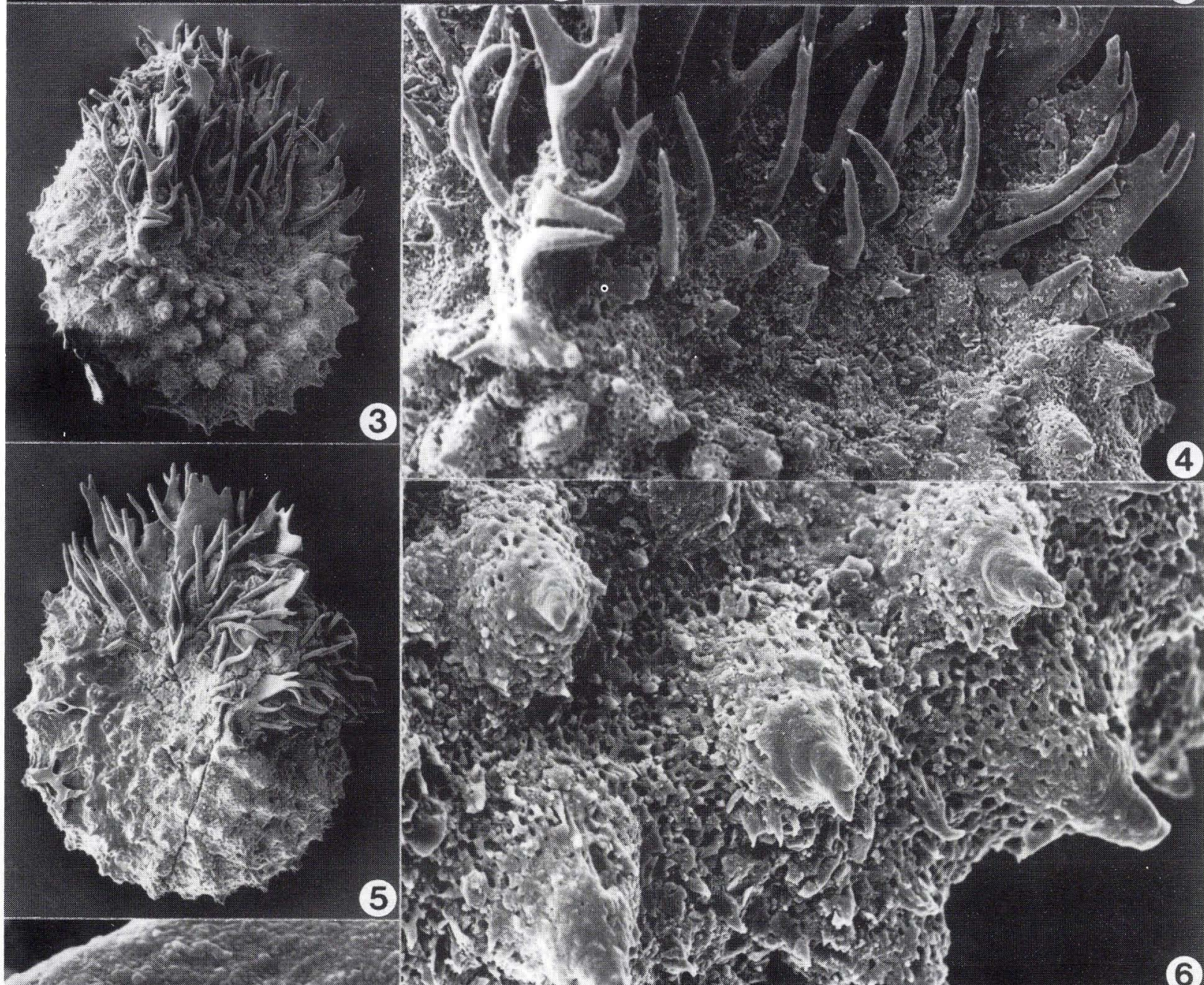

3

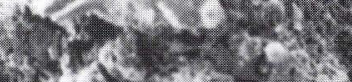

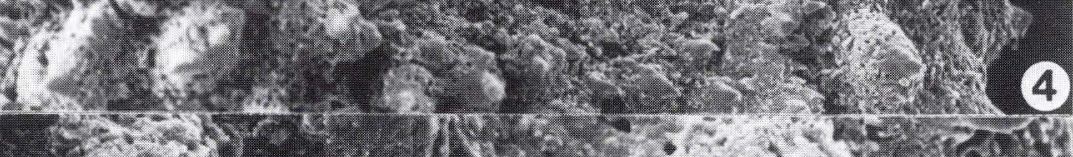

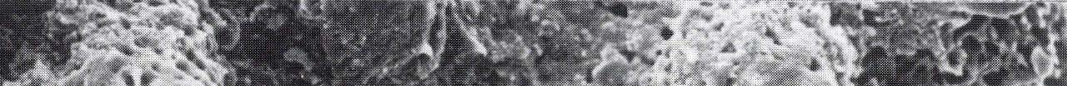

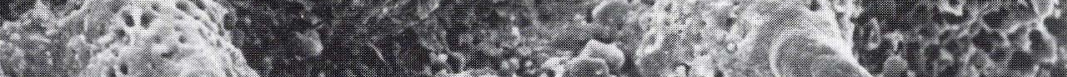

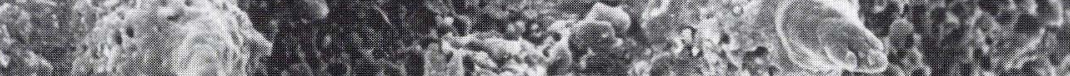

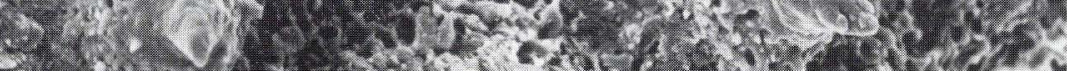

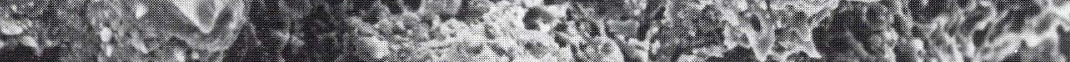

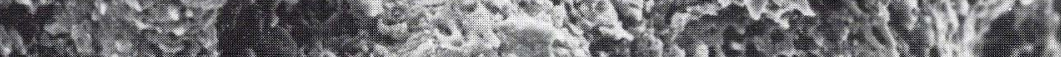

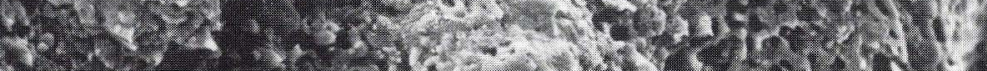

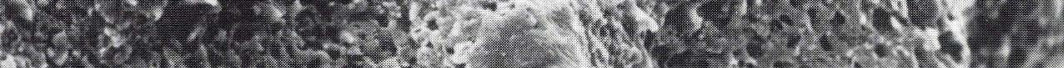
t

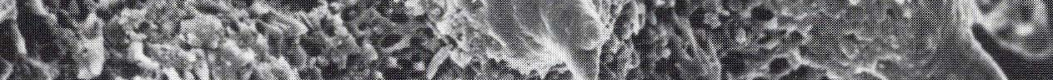

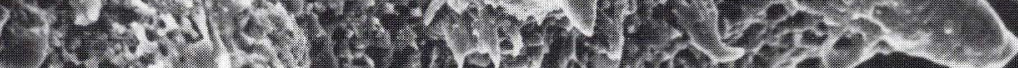

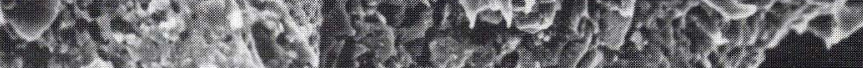

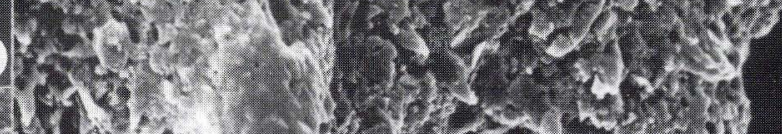

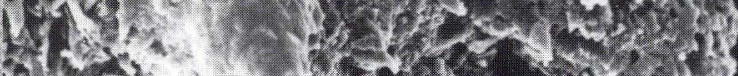

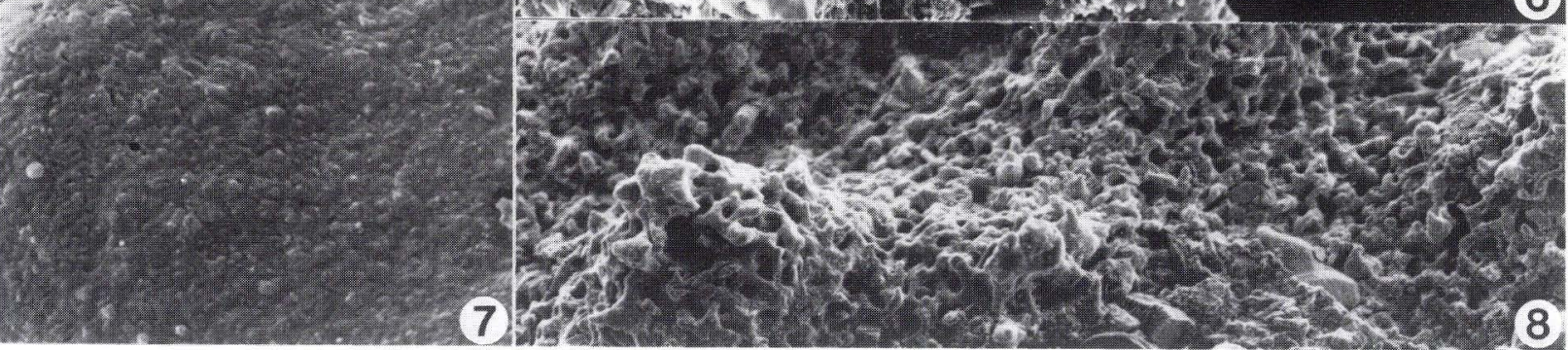




\section{PLATE 6}

Figs 1-8, Henrisporites bornholmensis; 1, proximal view of specimens from borehole 246.207, Robbedale, $\times 150$. 2, distal view of another specimen from same borehole, $\times 150.3$, same specimen as in Fig. 1; part of contact area, $\times 500$. 4, proximal view of a third specimen from borehole 246.207, ×160. 5-8, all same broken specimen from borehole 247.131c, Eskegård. 5, proximal view, $\times 150.6$, section of wall showing spongiose exoexine extending into triradiate flange, and membraneous intexine, $\times 2000$. 7 , close-up of contact area, $\times 500.8$, surface of zona, $\times 6000$. 

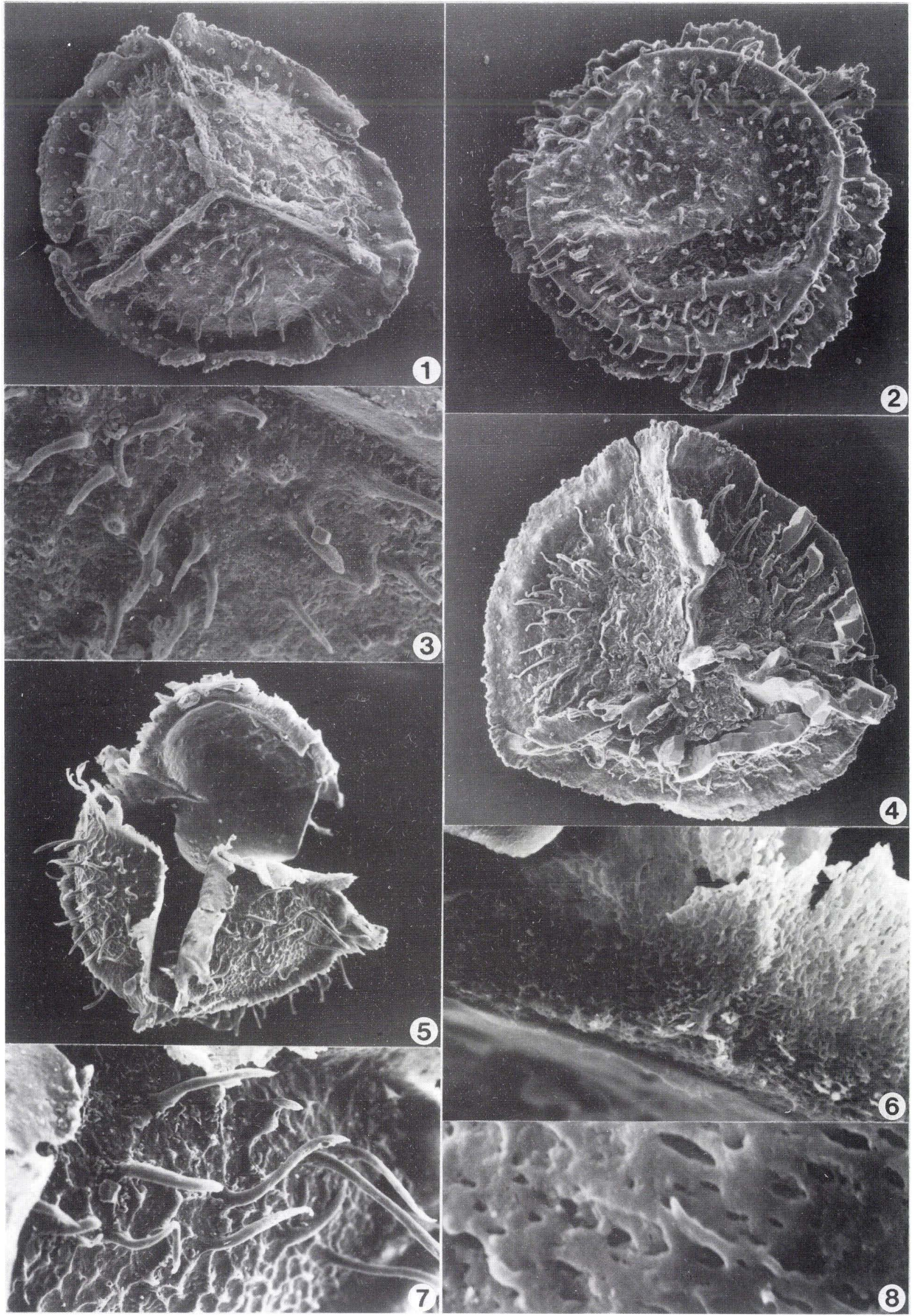

5

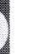




\section{PLATE 7}

Figs 1-8, Horstisporites areolatus. 1, proximal view of spore from Hasle Klinkerfabrik clay pit, $\times 100$. 2, close-up of part of proximal surface of same specimen, $\times 500.3$, proximal view of another example from Rønne Formation outcrop, $\times 120.4$, close-up of part of proximal face of same specimen, $\times 300.5-8$, all same broken specimen from Rønne Formation outcrop, 5 , showing thin intexine peeling away from inner surface of exoexine, $\times 500$. 6 , close-up of reticulum, $\times 1000$. 7, detail of wall layers, $\times 1300.8$, inner surface of intexine, $\times 7500$. 
Plate 7

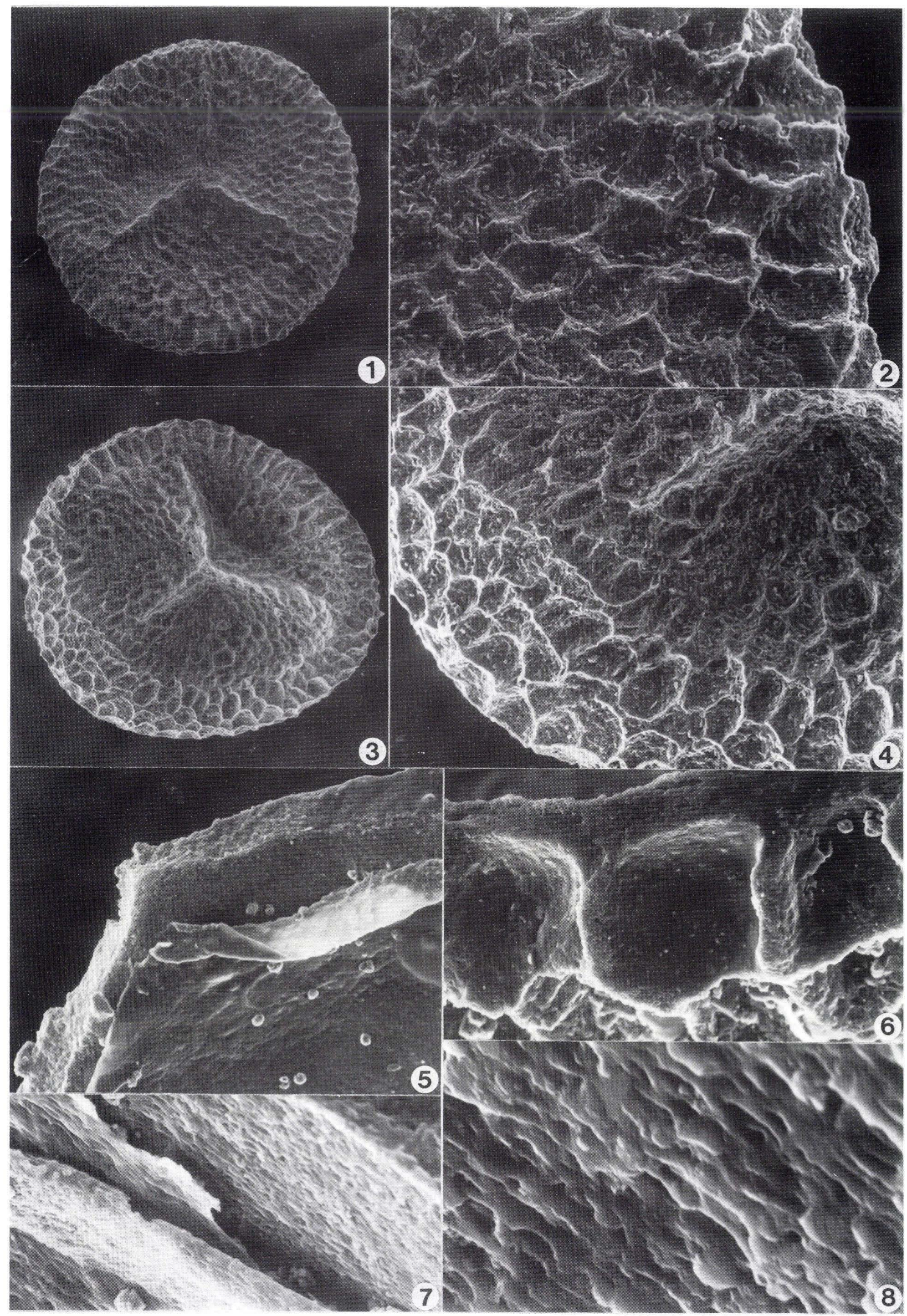




\section{PLATE 8}

Fig. 1, Horstisporites areolatus from Rønne Formation outcrop, equatorial view, $\times 140$.

Figs 2-8, Horstisporites harrisii. 2, oblique-proximal view of spore from borehole 244.83, Hasle Klinkerfabrik clay pit, $\times 150$. 3-5, another example from Munkerup Member outcrop. 3, oblique-proximal view, $\times 120$. 4, close-up of equatorial surface, $\times 500.5$, sculpture of contact area, $\times 1000.6$, specimen from Hasle Klinkerfabrik clay pit, $\times 100$. 7 , section of wall of broken specimen from Rønne Formation outcrop showing exoexine and intexine, but fragment is dirty; hence structural details are obscured, $\times 500.8$, close-up of part of contact face and equatorial area of specimen in Fig. $6, \times 100$. 

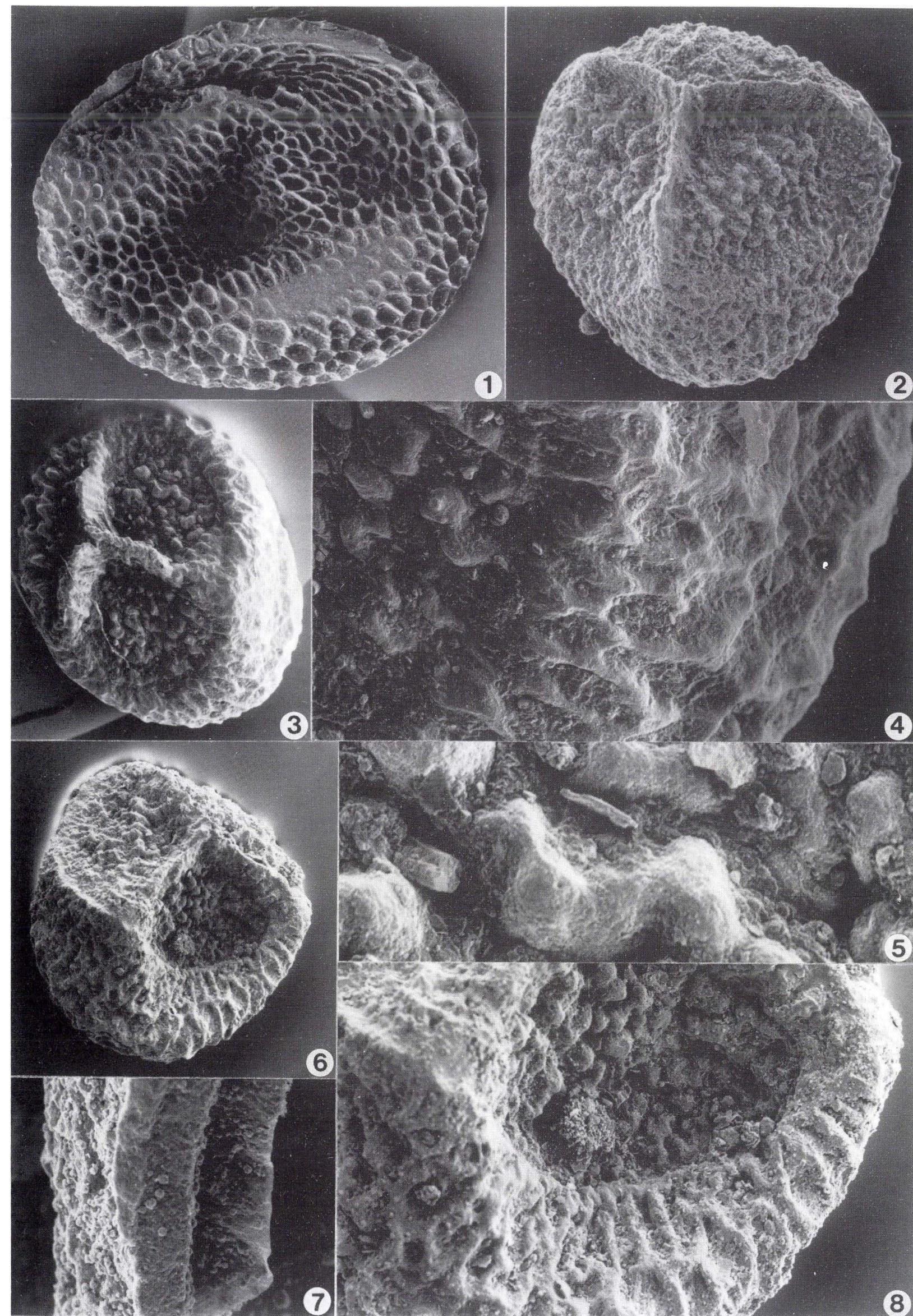

6
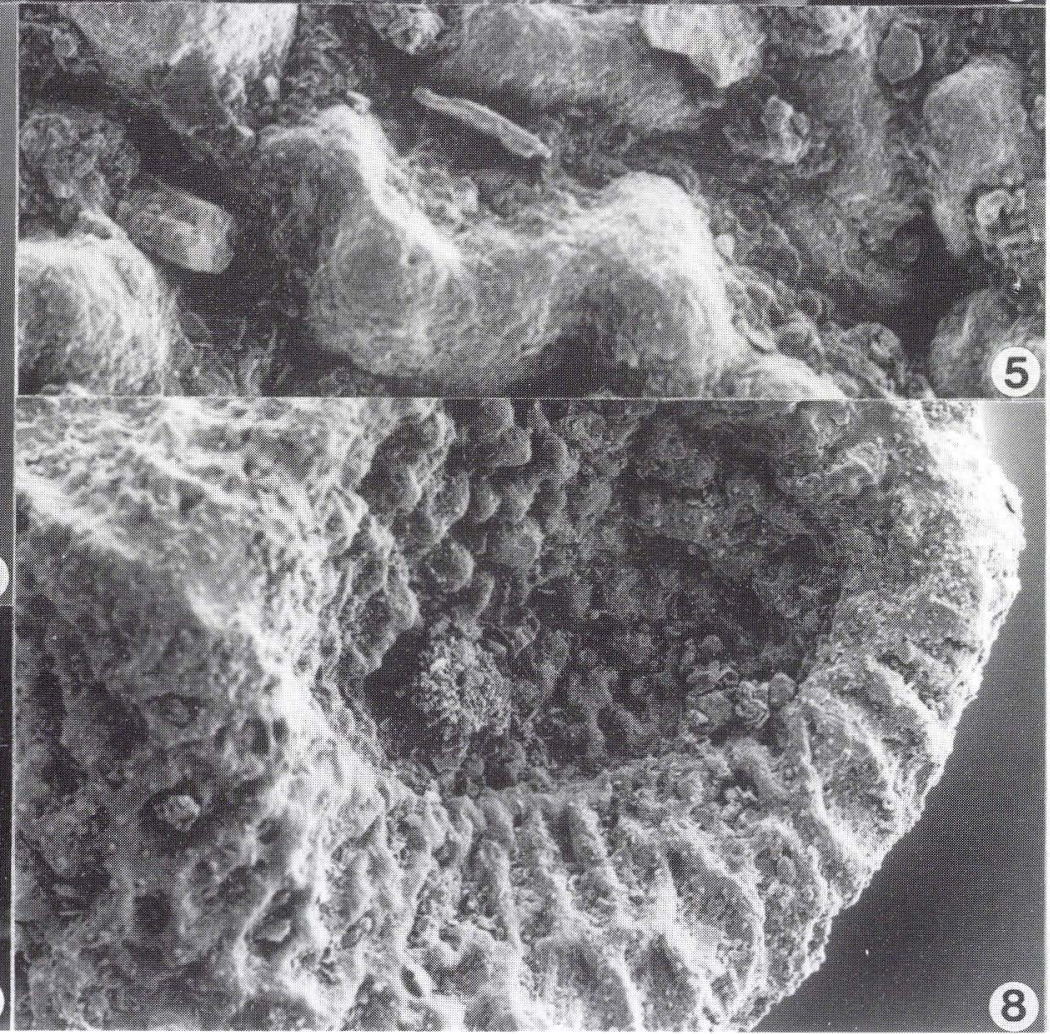


\section{PLATE 9}

Figs 1-5, Horstisporites planatus. 1-4, all same specimen from Sose Bugt Member outcrop. 1, proximal view, $\times 200.2$, close-up of contact area, $\times 400.3$, same as 2 but at higher magnification, $\times 1600$. 4, detail of surface of sculptured exoexine on proximal face, $\times 5000$. 5, apparently granular distal surface of another specimen from same outcrop; at higher magnification it is seen to be reticulate, $\times 150$.

Figs 6-9, Hughesisporites galericulatus, all same specimen from borehole 246.307a. Skyttegård. 6, proximal view, ×200. 7, close-up of part of triradiate ridge and adjacent appendages, $\times 550.8$, close-up of proximal surface away from triradiate area, $\times 2000$. 9 , as for 8 , detail, $\times 5000$. 

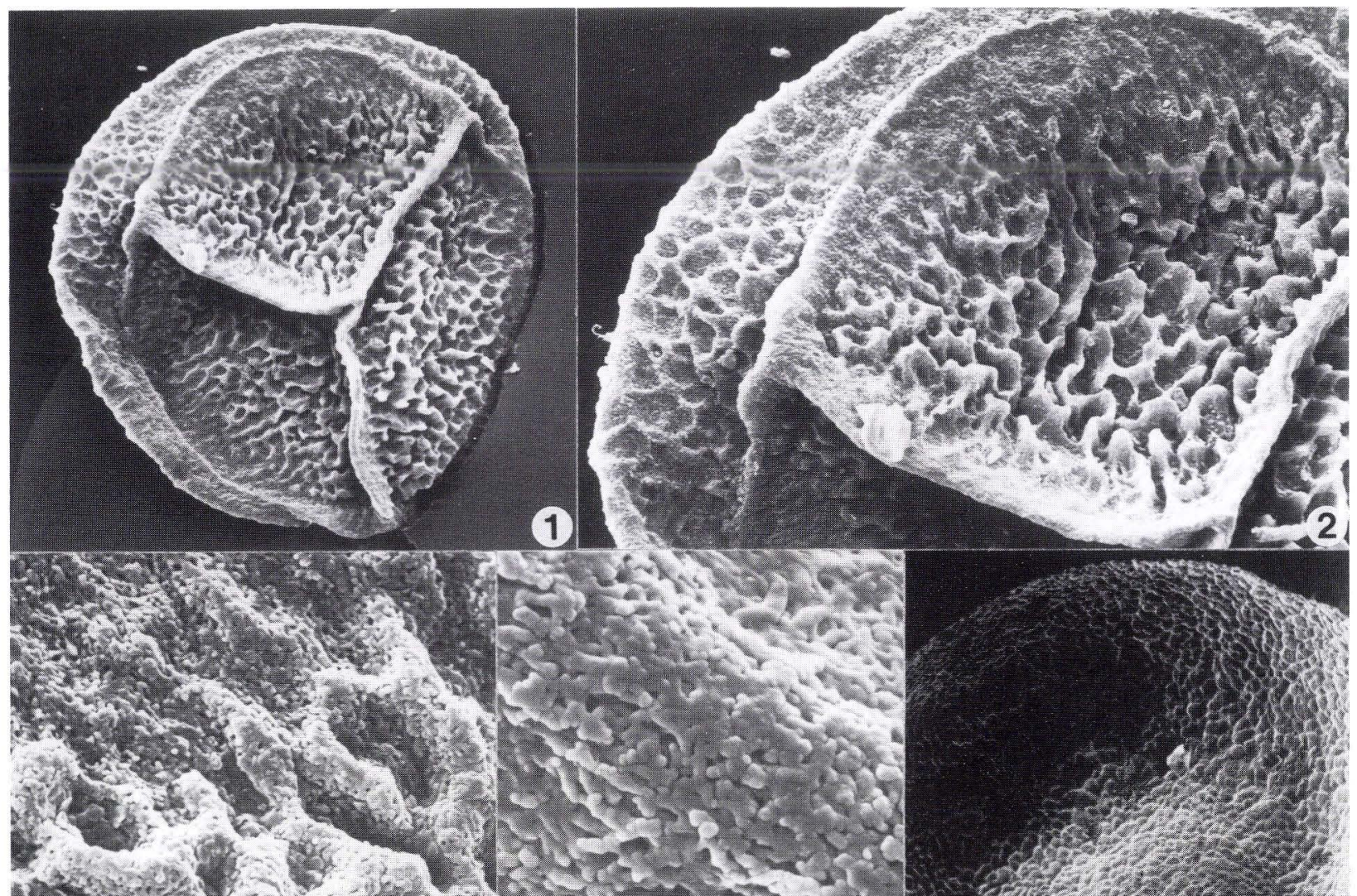

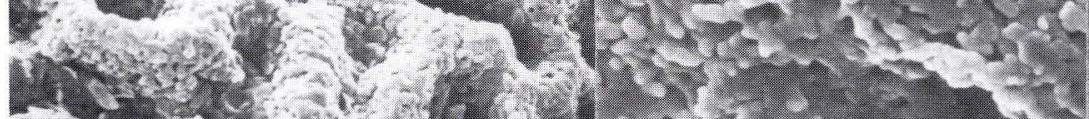

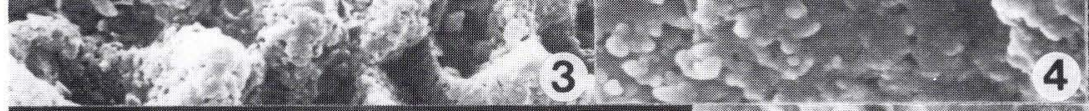
5

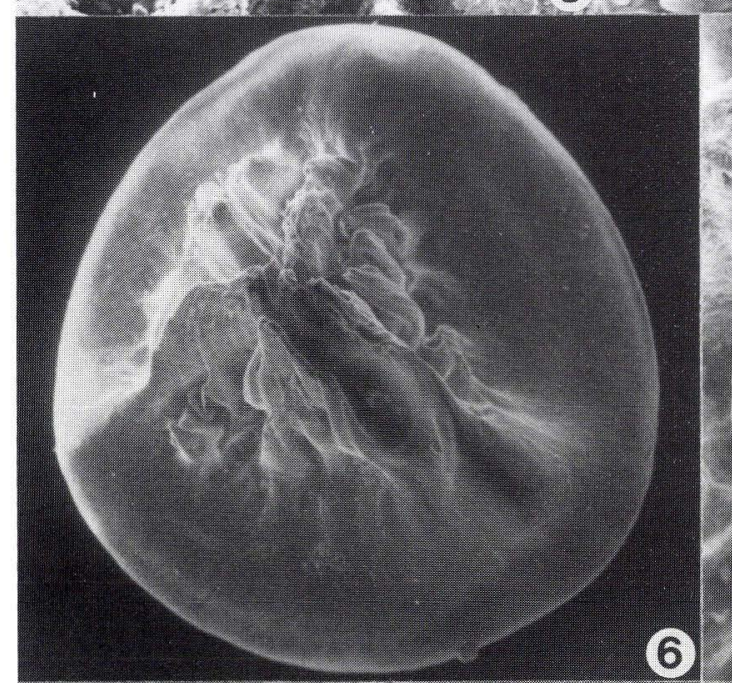

8
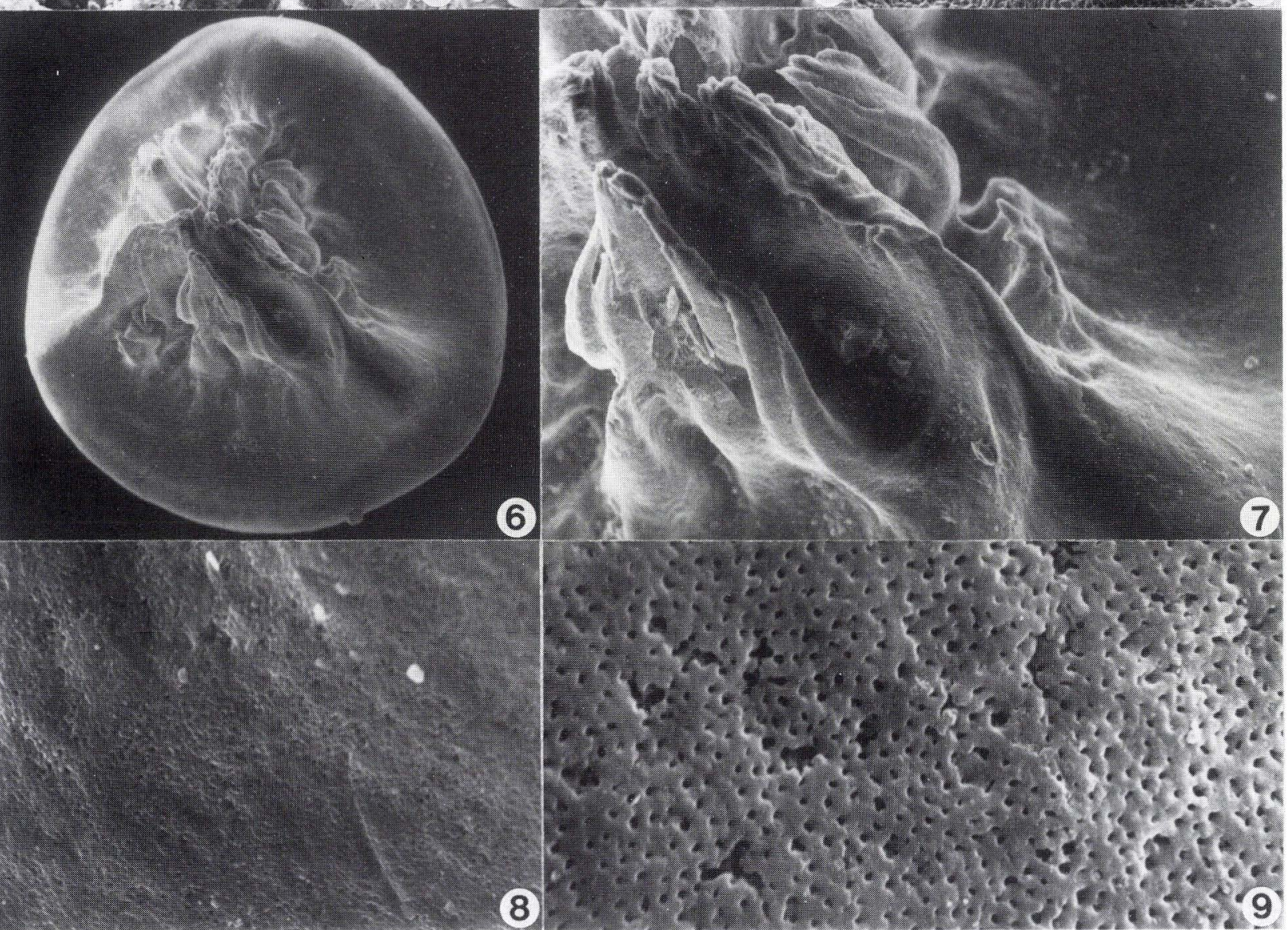
PLATE 10

Figs 1, 3, Hughesisporites galericulatus from Skyttegård outcrop. 1, specimen broken in half, $\times 250$. 3, cross-section of distal exoexine, $\times 2000$.

Figs 2, 4-8, Hughesisporites variabilis from borehole 244.105, Hasle Klinkerfabrik clay pit. 2, 4, 6, same specimen. 2, proximal view, $\times 100$; for reflected light photograph of same specimen, see Pl. 20, fig. 17. 4, close-up of triradiate ridge and rugulate sculpture of adjacent proximal face, $\times 500$. 6, surface of exoexine of proximal face close to equator, $\times 5000.5,7,8$, another specimen from same borehole. 5, proximal view, $\times 100$. 7, detail of equatorial surface area; reticulation of surface partly plugged with extraneous matter, $\times 5000.8$, detail of surface of triradiate ridge, similarly affected by particulate detritus, $\times 5000$. 


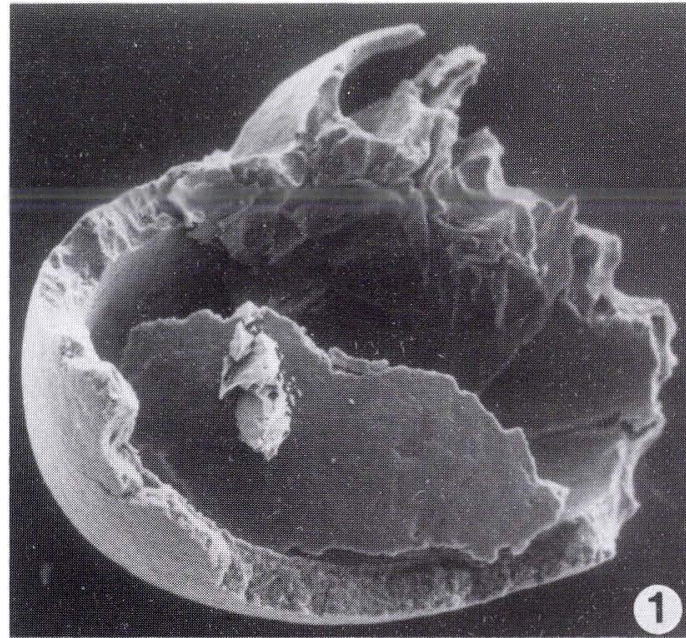

(2)
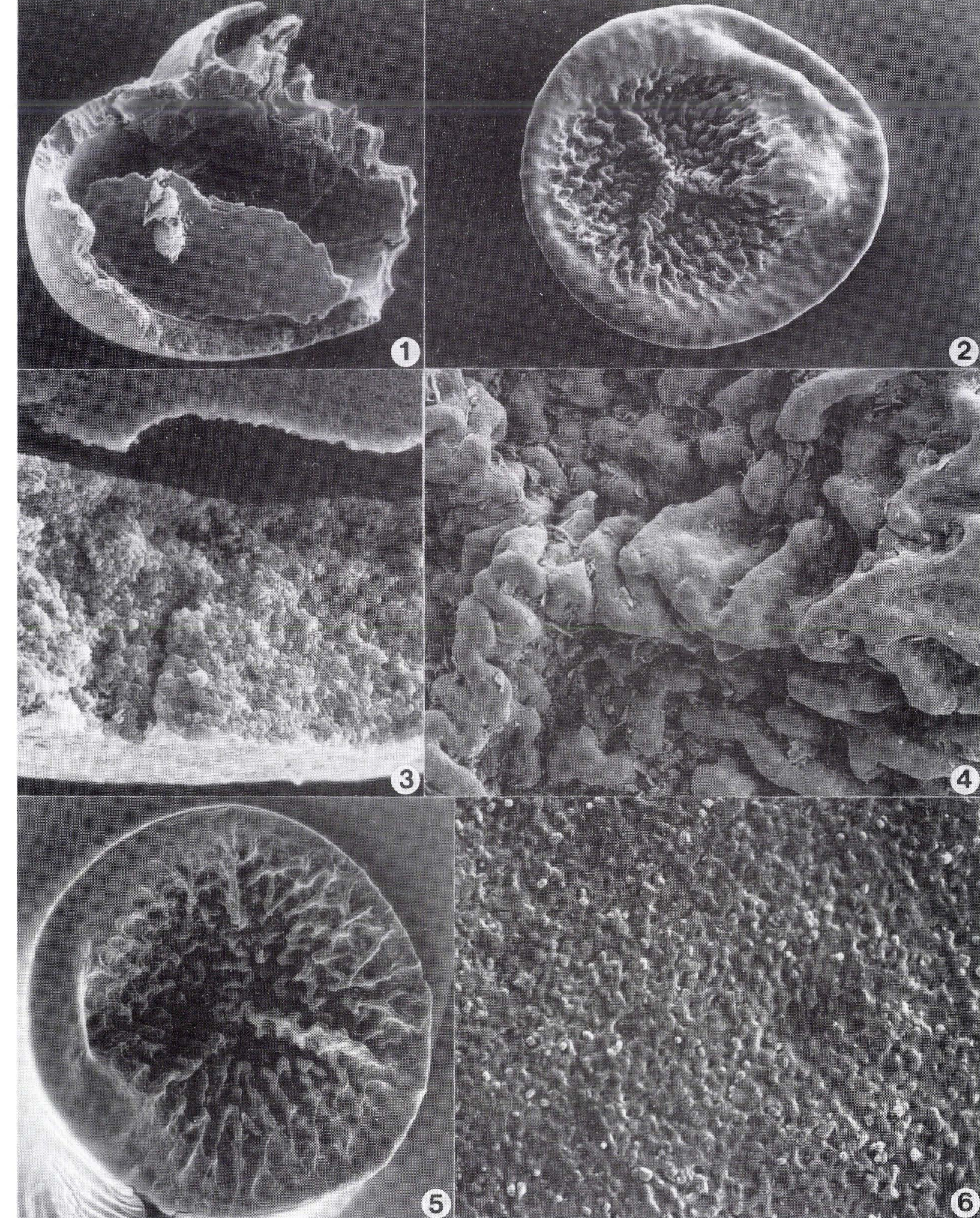

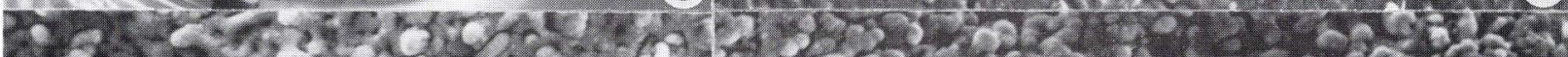

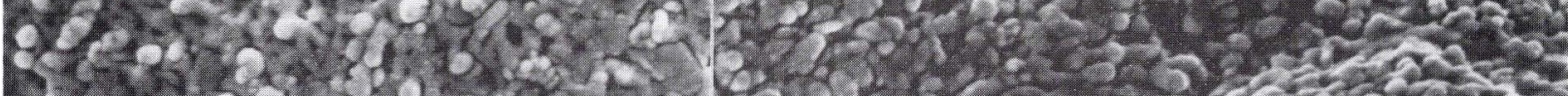

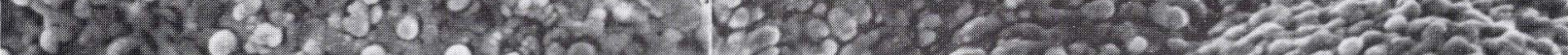
12.

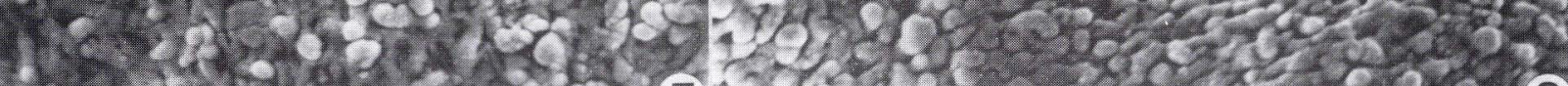

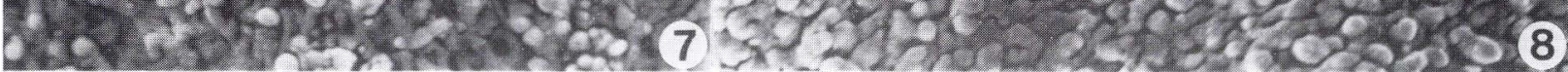




\section{PLATE 11}

Figs 1, 2, Maexisporites sp. cf. M. misellus, specimen from Hasle Klinkerfabrik clay pit. 1, proximal view, ×200. 2, detail of sculptured surface, $\times 7500$.

Figs 3-8, Maexisporites soldanellus. 3, 4, 7, same specimen from Hasle Klinkerfabrik clay pit. 3, proximal view, $\times 100.4$, close-up of triradiate ridge and part of adjacent proximal face, $\times 400.7$, part of ridge at slightly higher magnification, $\times 500.5$, 6, fragment from Hasle Klinkerfabrik clay pit. 5, cross-section of exoexine showing closely spaced rods of sporopollenin which give wall a granular appearance, $\times 10000$. 6 , reticulate outer surface of exoexine, $\times 10000.8$, lateral view of another specimen from borehole 244.83, Hasle Klinkerfabrik clay pit, $\times 200$. 


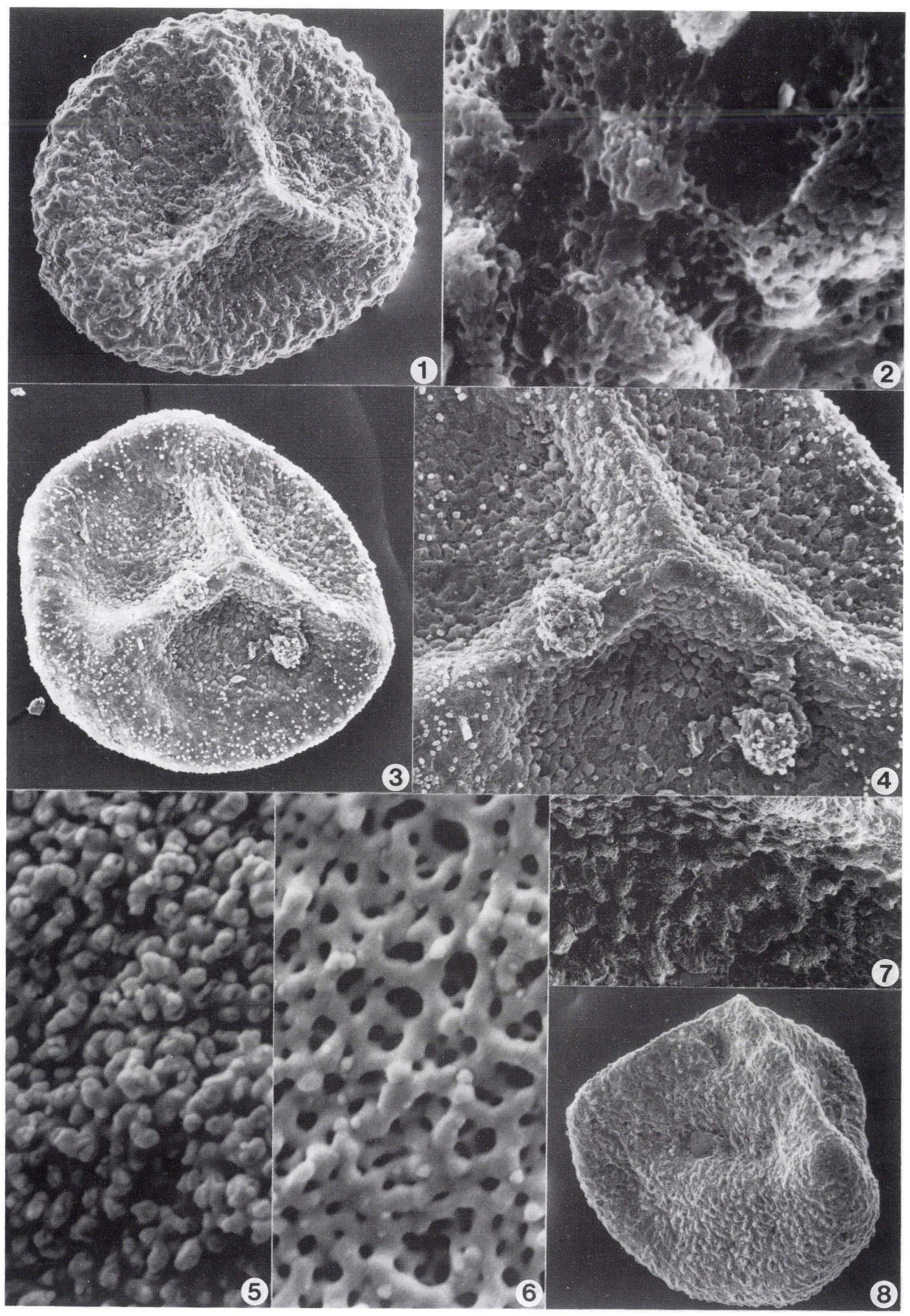




\section{PLATE 12}

Figs 1, 2, Minerisporites marginatus. 1, oblique-lateral view of damaged spore from Eskegård outcrop, ×200. 2, close-up of proximal surface of same specimen, $\times 2500$.

Figs 3, 4, Minerisporites sp. cf. M. marginatus, same specimen from borehole 247.130f, Eskegård. 3, proximal view, $\times 200$. 4, close-up of part of triradiate ridge, zona and proximal surface, $\times 700$.

Figs 5-8, Minerisporites richardsonii. 5, oblique-proximal view of spore from borehole 244.105, Hasle Klinkerfabrik clay pit, $\times 150$. 6, close-up of surface of same specimen, $\times 2000.7$, lateral view of another specimen, Hasle Klinkerfabrik clay pit, $\times 200$. 8 , lateral view of a third specimen, Hasle Klinkerfabrik, $\times 150$. 


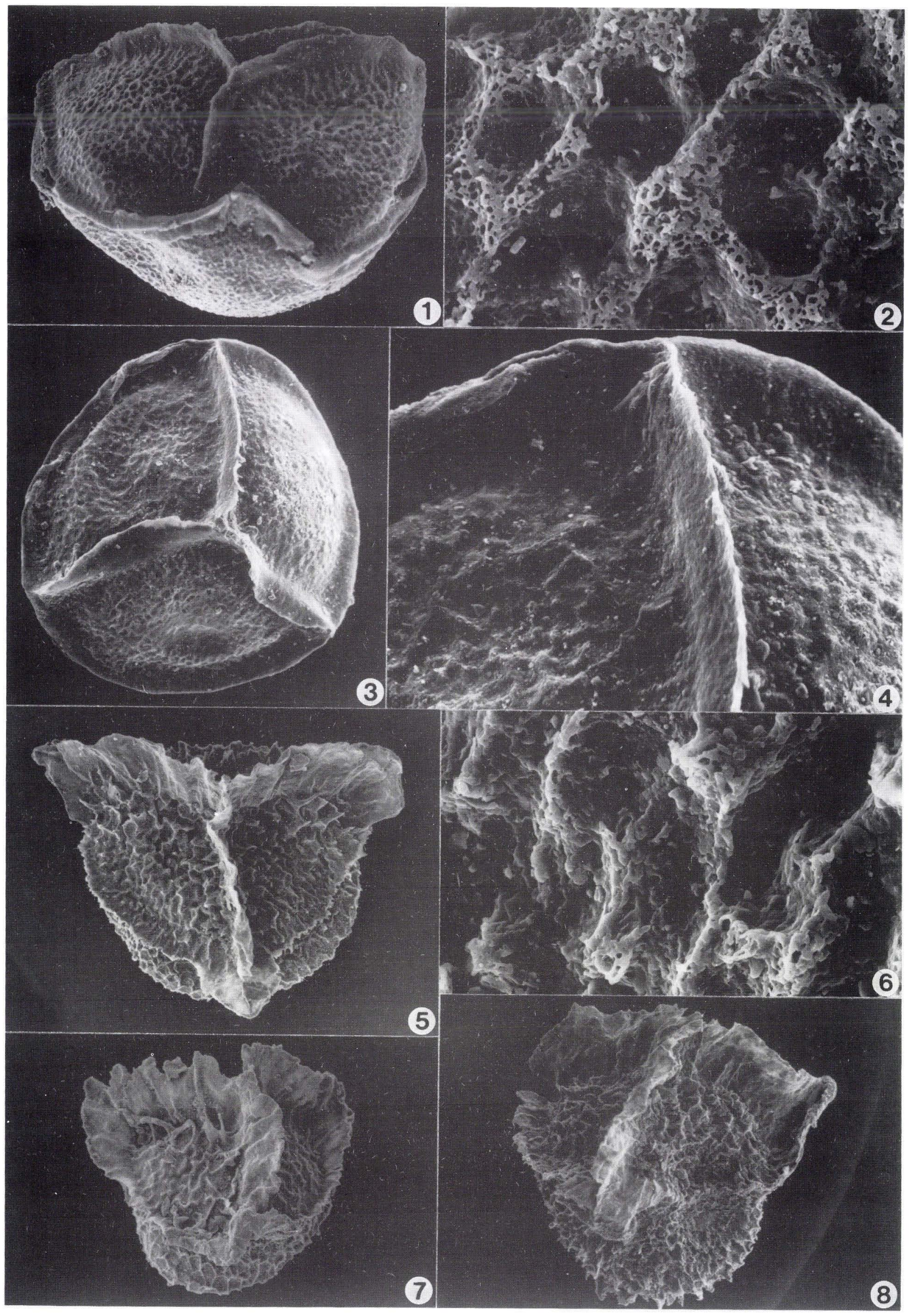




\section{PLATE 13}

Fig. 1, Minerisporites richardsonii from Hasle Klinkerfabrik clay pit, proximal view, $\times 150$.

Figs 2-5, 7, 8, Minerisporites volucris. 2-4, 8, all same specimen from borehole 244.105, Hasle Klinkerfabrik clay pit. 2, part of triradiate flange and proximal face showing spinose sculpture, $\times 400.3$, equatorial view of laterally compressed specimen, $\times 140$. 4, part of distal surface showing closely spaced spines, $\times 400.8$, close-up of auriculate development of zona, $\times 500.5,7$, another specimen from same borehole. 5, lateral view, $\times 150.7$, close-up of flattened spinose elements of distal sculpture, $\times 1000$

Fig. 6, Minerisporites sp. from borehole 247.130f, Eskegård, proximal view, $\times 200$. 


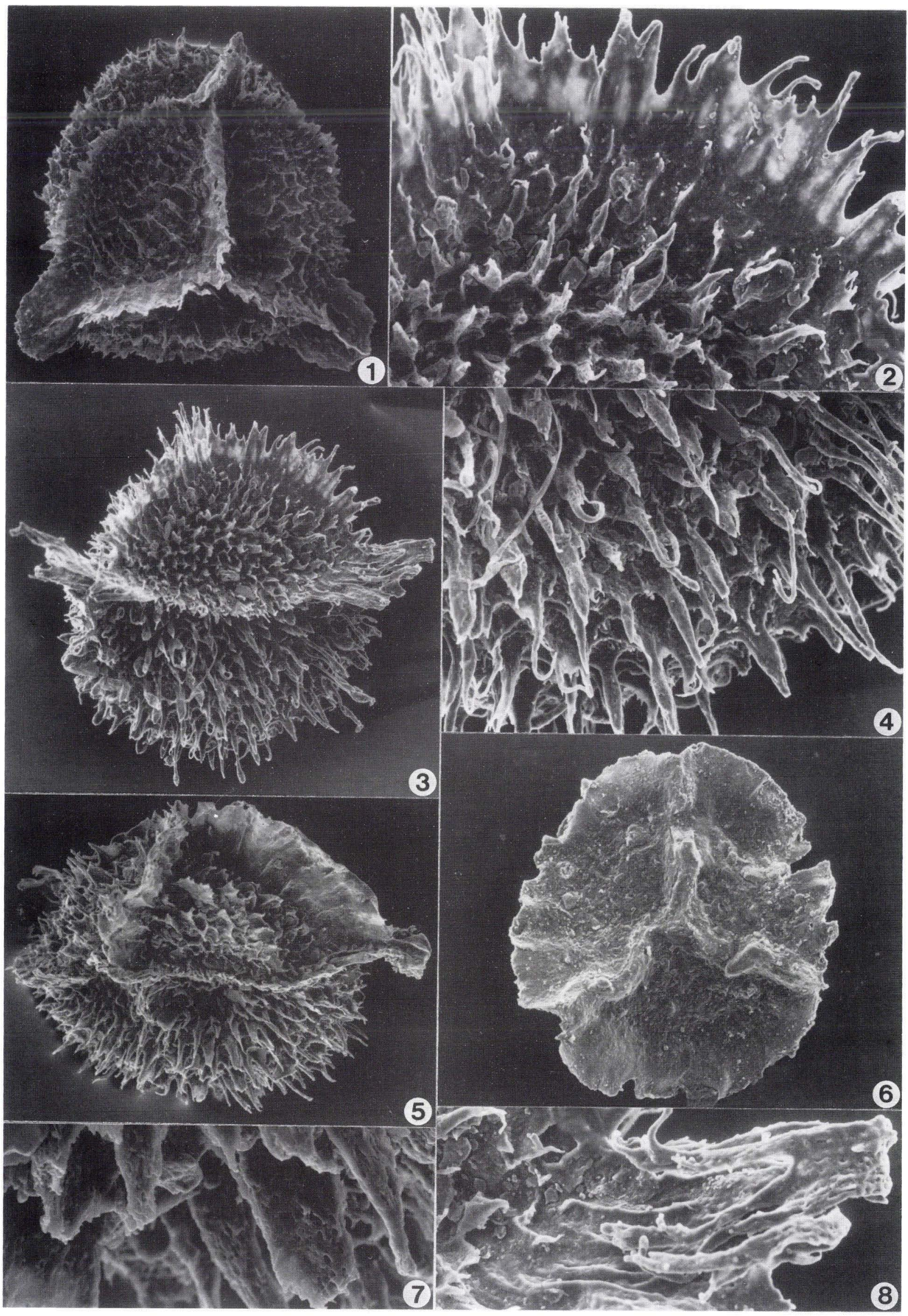




\section{PLATE 14}

Fig. 1, Minerisporites sp. from borehole 247.130f, Eskegård, proximal view, $\times 300$.

Figs 2-8, Nathorstisporites hopliticus, all from Munkerup Member outcrop. 2, proximal view of very degraded specimen, $\times 150$. 3, 4, 6-8, all same specimen from Munkerup Member outcrop. 3, equatorial view, $\times 100$. 4, close-up of part of equatorial region and proximal surface, $\times 300$. 6 , close-up of part of distal surface, $\times 750.7$, close-up of part of scabrate, homogeneous surface of proximal appendage, $\times 2500.8$, close-up of subequatorial part of proximal surface, $\times 1000$. 5 , lateral view of another specimen from same locality, $\times 100$. 

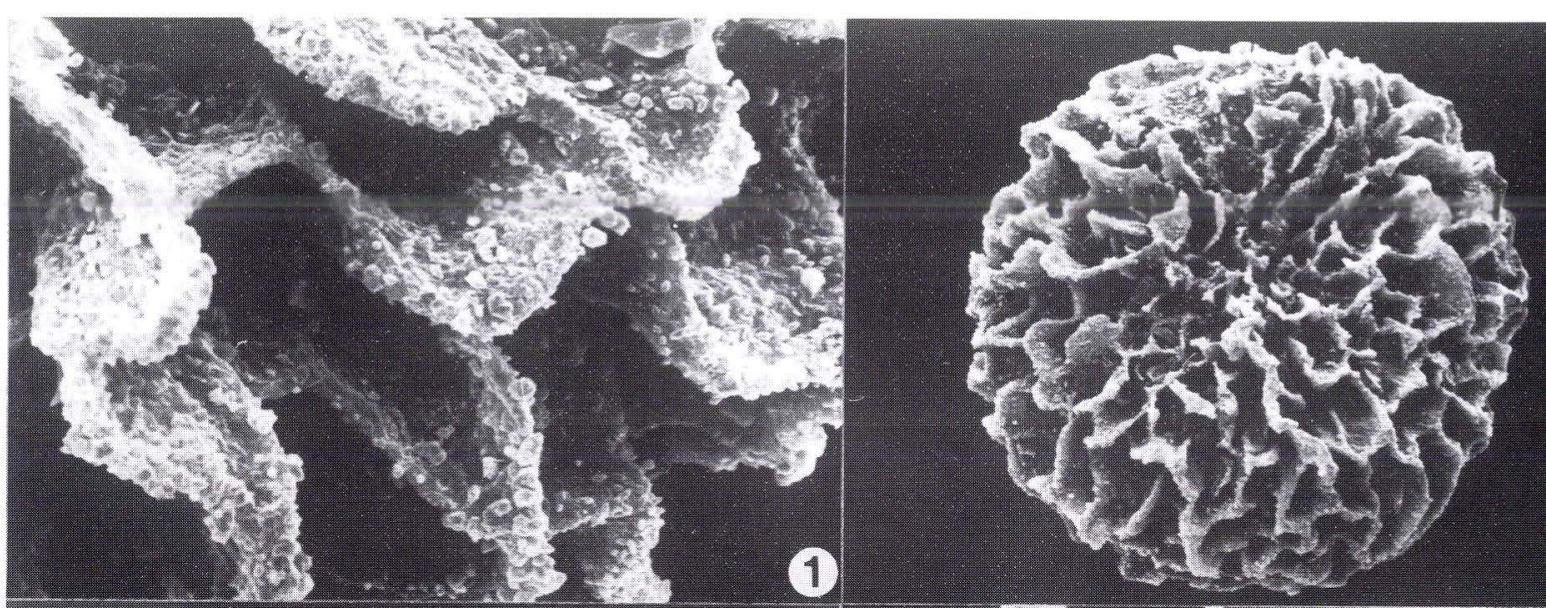

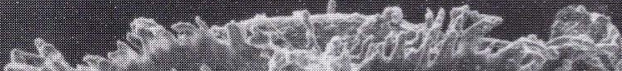

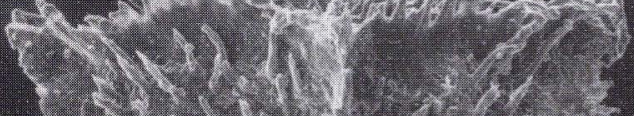

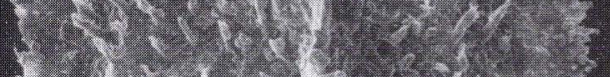

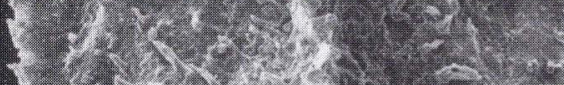

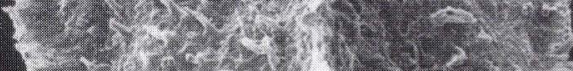

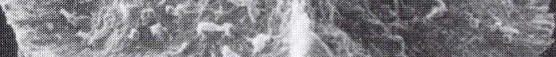
s.

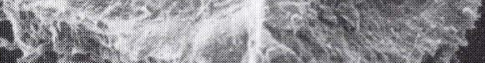

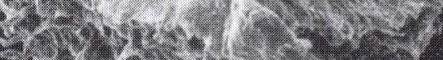
(5) $54+5 x=3$

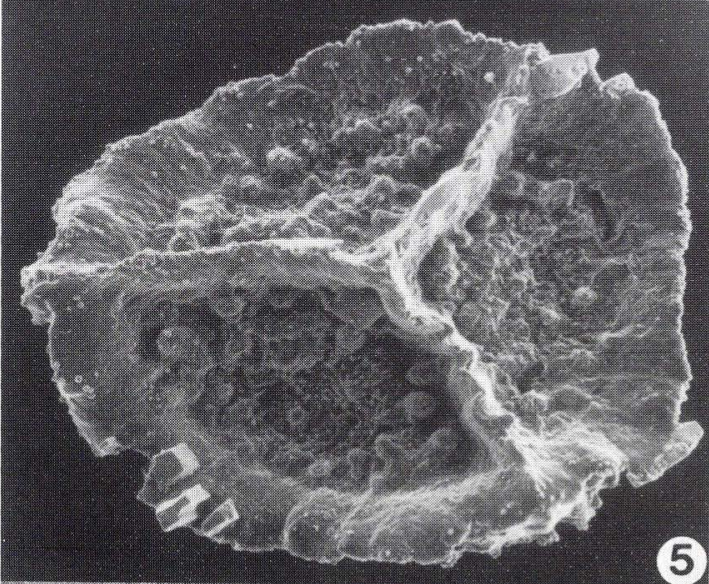

5
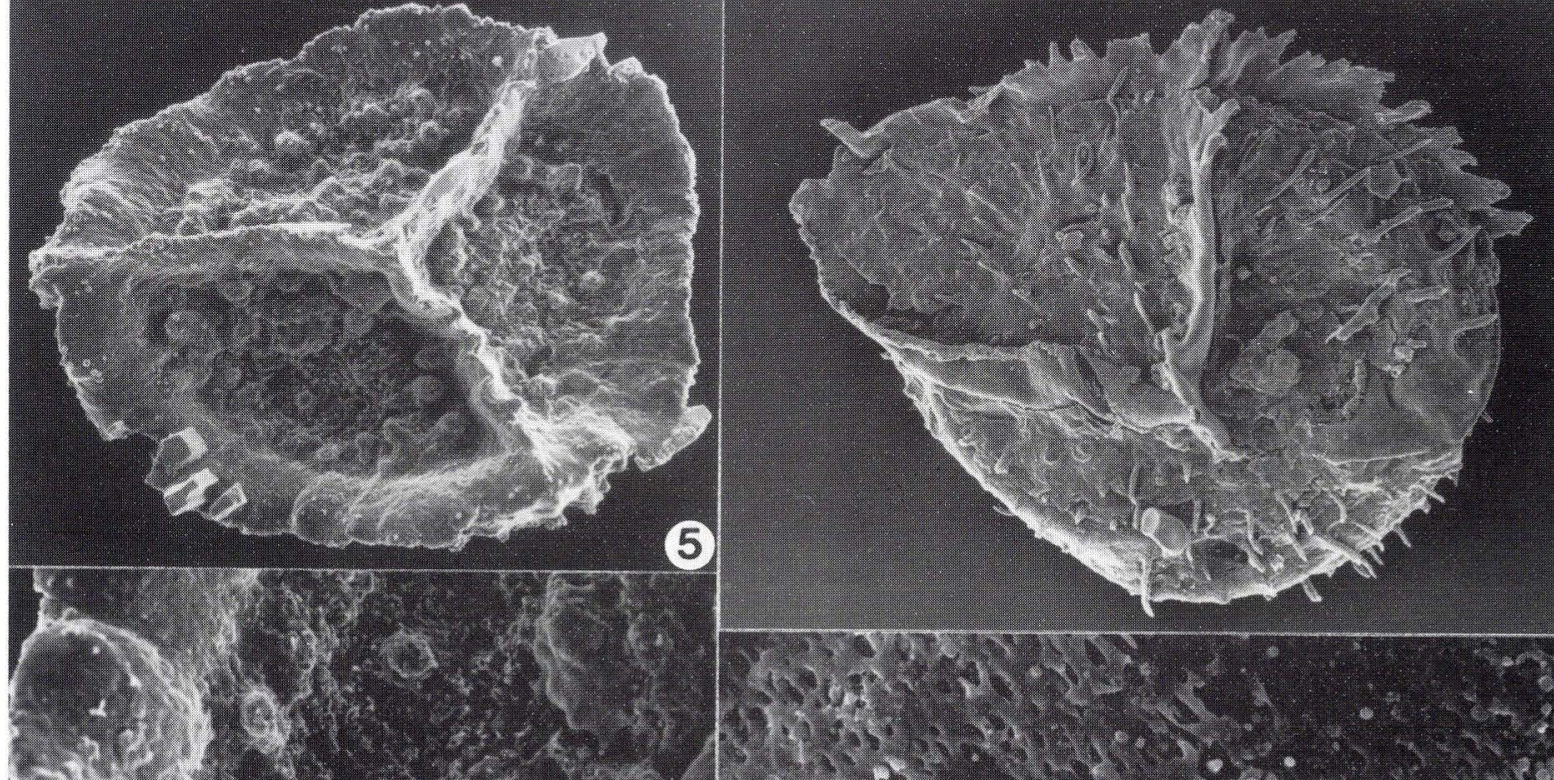

6.
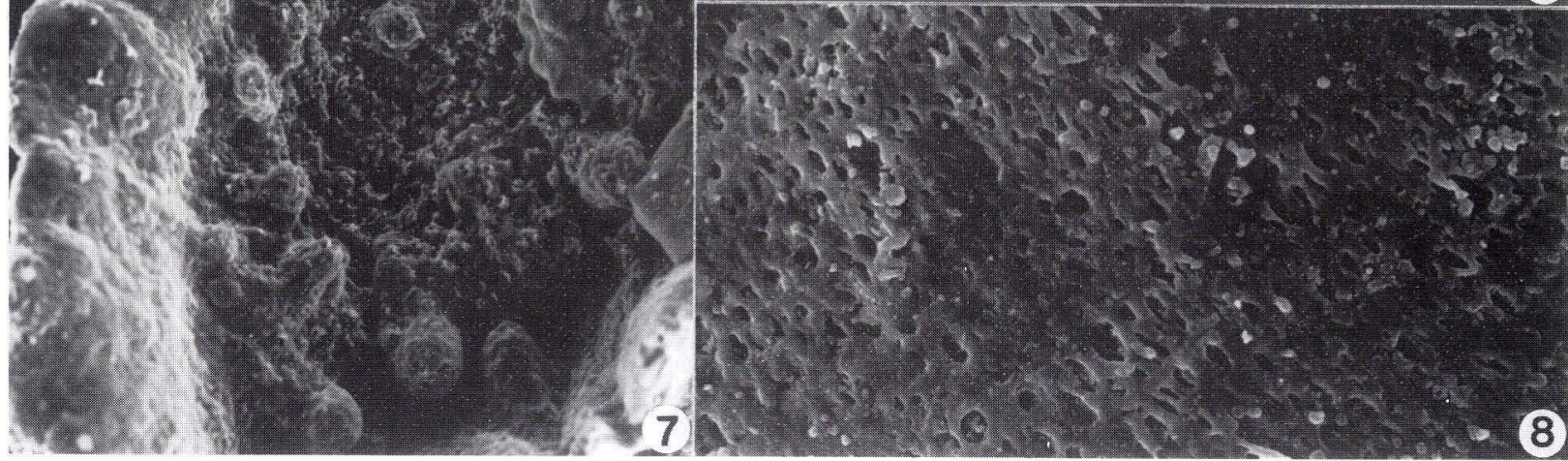


\section{PLATE 15}

Figs 1-8. Paxillitriletes kristinae. 1, proximal view of spore from borehole 244.232, Bakkegård, $\times 140.2$, close-up of processes adjacent to, and comprising part of, triradiate flange of same specimen, $\times 400.3$, close-up of zona of second spore, Skyttegård outcrop, $\times 1500$. 4, part of proximal face of same specimen with broken appendages adjacent to triradiate flange, $\times 330.5$, part of broken specimen from borehole 246.307a in cross-section showing membraneous intexine beneath much thicker, spongiose exoexine, $\times 1000$. 6, cross-section of exoexine of another fragment underlain by a closely adhering membraneous intexine, Skyttegård outcrop, $\times 2000.7$, proximal view of specimen from borehole 246.207 , Robbedale, $\times 150.8$, sculpture of proximal surface of same specimen as fig. $4, \times 1500$. 


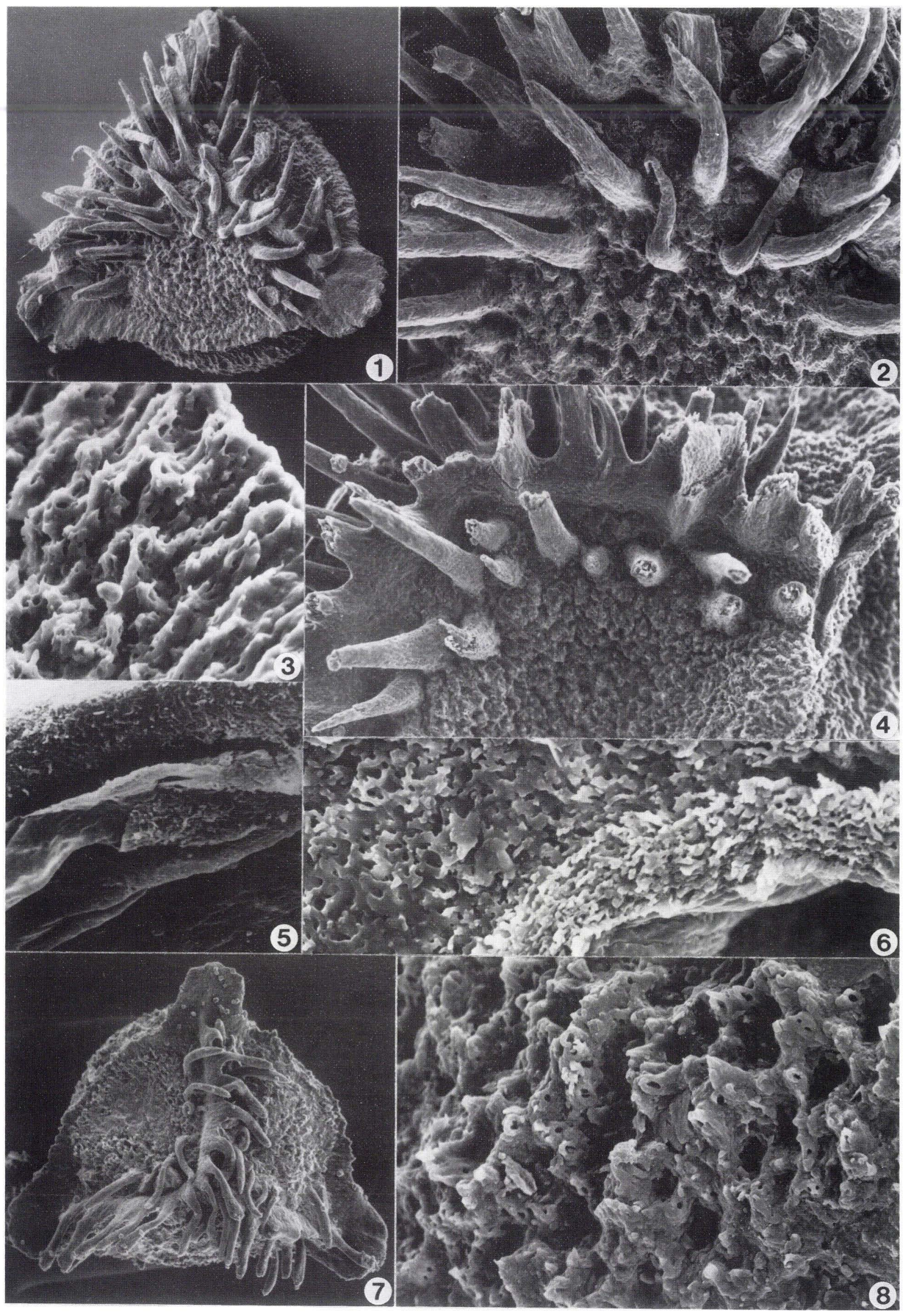


PLATE 16

Fig. 1, Paxillitriletes kristinae, oblique-lateral view of specimen from borehole 244.232, Bakkegård, $\times 140$.

Figs 2-4, Paxillitriletes phyllicus, all same specimen from Skyttegård outcrop. 2, lateral view, $\times 220$. 3, proximal sculpture, $\times 1000$. 4, part of proximal face showing triradiate flange, adjacent membraneous processes and reticulum, $\times 400$.

Figs 5-7, Paxillitriletes sp. cf. P. reticulatus from borehole 246.307a, Skyttegård. 5, lateral view, $\times 250$. 6, close-up of part of proximal sculpture and membraneous elevations adjacent to triradiate flange, $\times 500.7$, detail of proximal reticulum showing spongiose exoexine, $\times 2000$. 

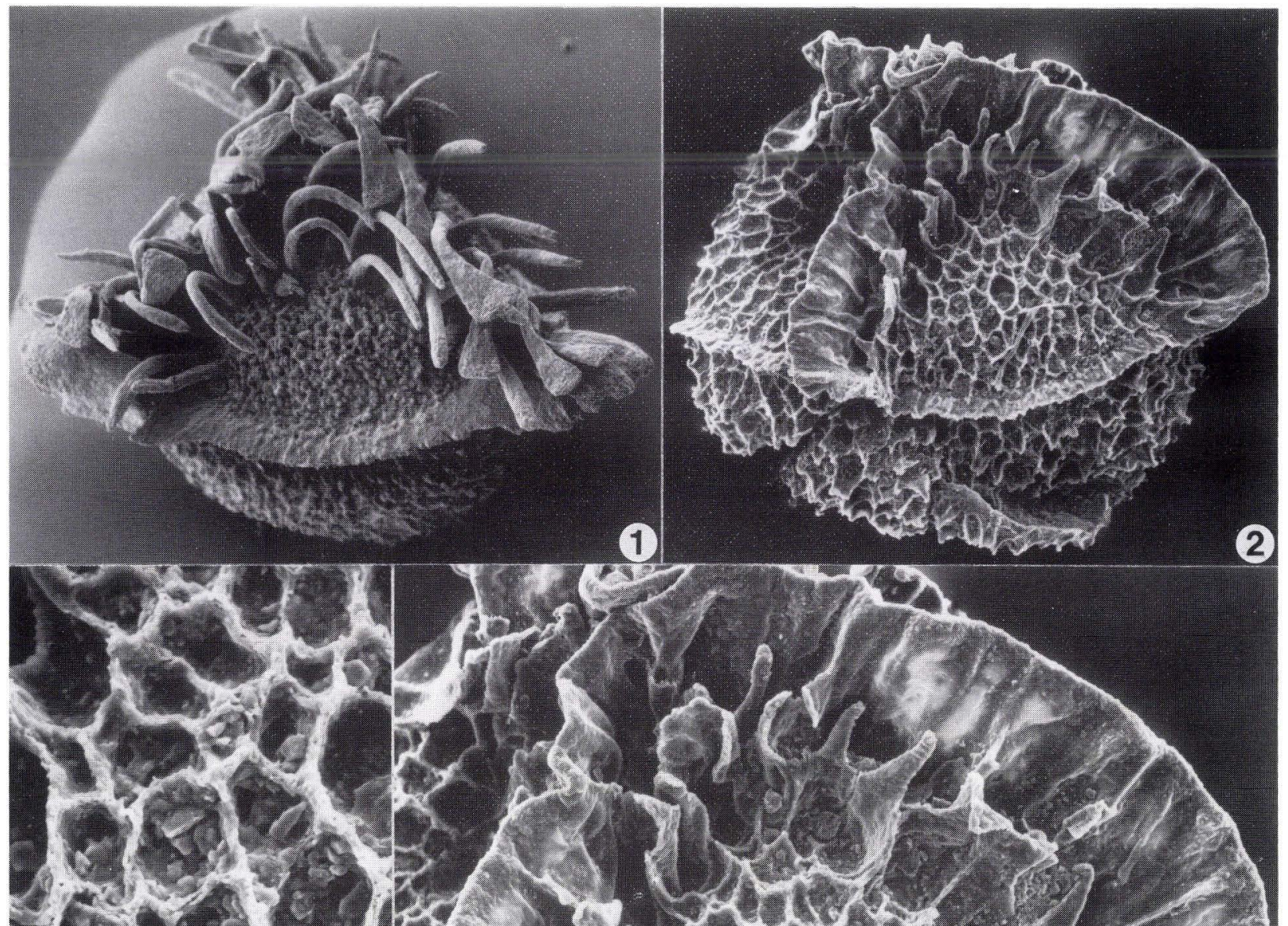

(1)
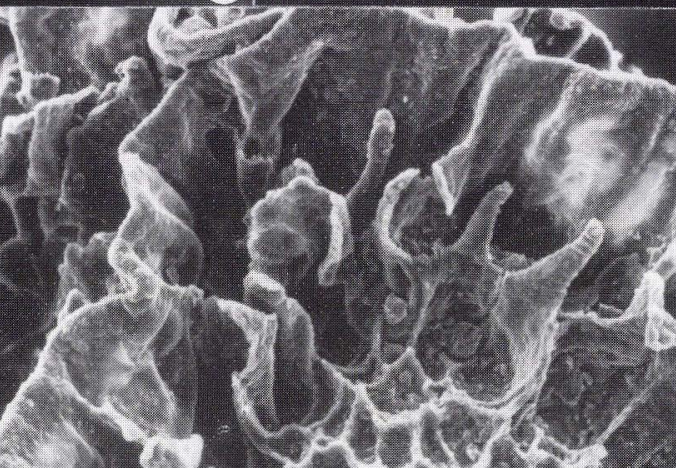

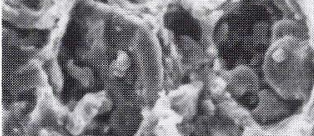

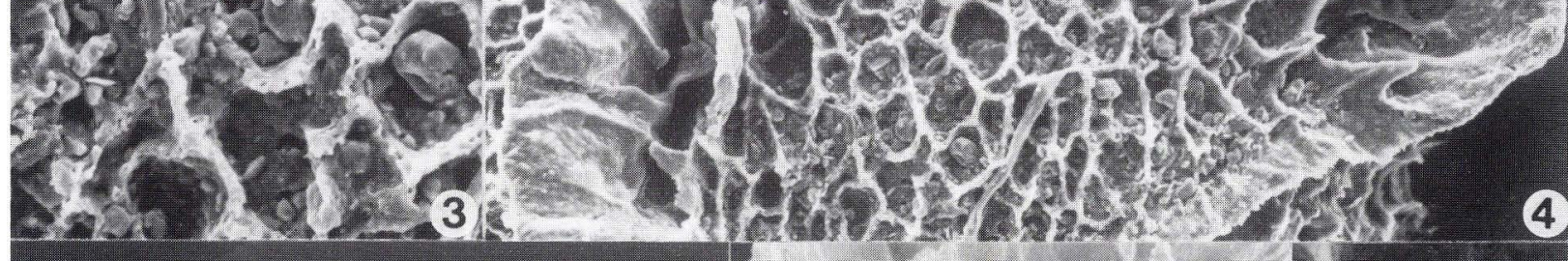

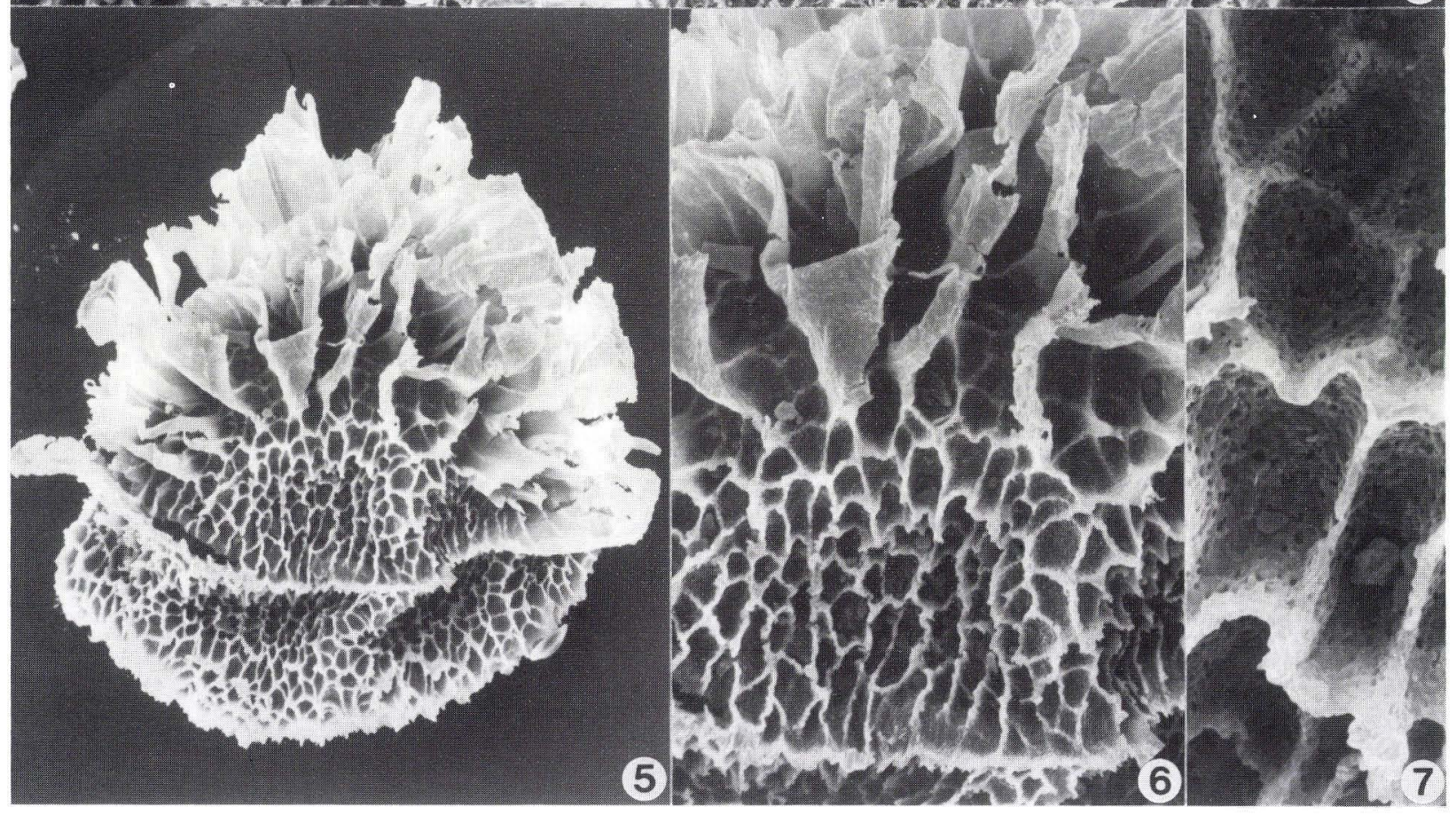




\section{PLATE 17}

Figs 1-3, Paxillitriletes sp. cf. P. reticulatus, all same specimen, from borehole 246.307 a, Skyttegård. 1, lateral view, $\times 170.2$, part of ribbed triradiate flange, $\times 1000$. 3, reticulate sculpture on distal surface, detail, $\times 3000$.

Fig. 4, Paxillitriletes sp. 1 from Skyttegård outcrop, oblique-lateral view, $\times 200$.

Figs 5-7, Paxillitriletes sp. 2, all same specimen from Hasle Klinkerfabrik clay pit. 5, oblique-proximal view, $\times 250$. 6, part of zona and appendages adjacent to triradiate flange, $\times 2000.7$, close-up of rugulate sculpture on proximal face, $\times 1000$.

Fig. 8, Paxillitriletes sp. 3 from Vellengsby outcrop, proximal view, $\times 150$.

Fig. 9, Striatriletes sulcatus from borehole 244.83, Hasle Klinkerfabrik clay pit, oblique-proximal view, $\times 200$. 

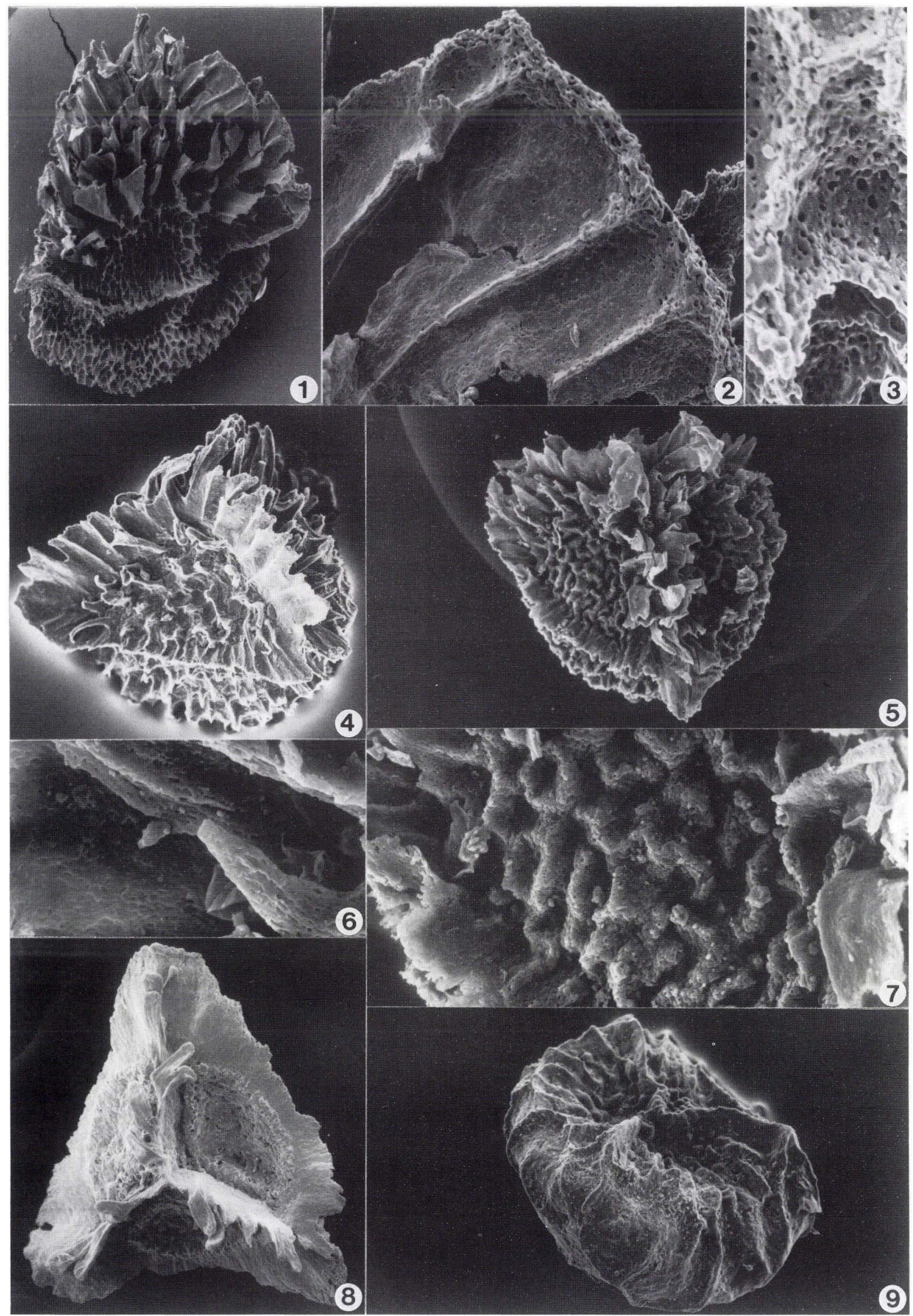


\section{PLATE 18}

Figs 1-8, Paxillitriletes rasmusii. 1-4, all same specimen from Skyttegård outcrop. 1, proximal view, $\times 100$. 2, close-up of part of proximal face showing triradiate flange, sculpture of contact area and zona, $\times 250.3$, proximal sculpture at higher magnification, $\times 1000.4$, detail of outer surface of exoexine, $\times 5000$. 5-8, second specimen, Skyttegård outcrop. 5, equatorial view, $\times 120$. 6 , surface of auricula, $\times 400.7$, distal surface beneath zona, $\times 400$. 8, close-up of spinose sculpture of proximal face, $\times 400$. 


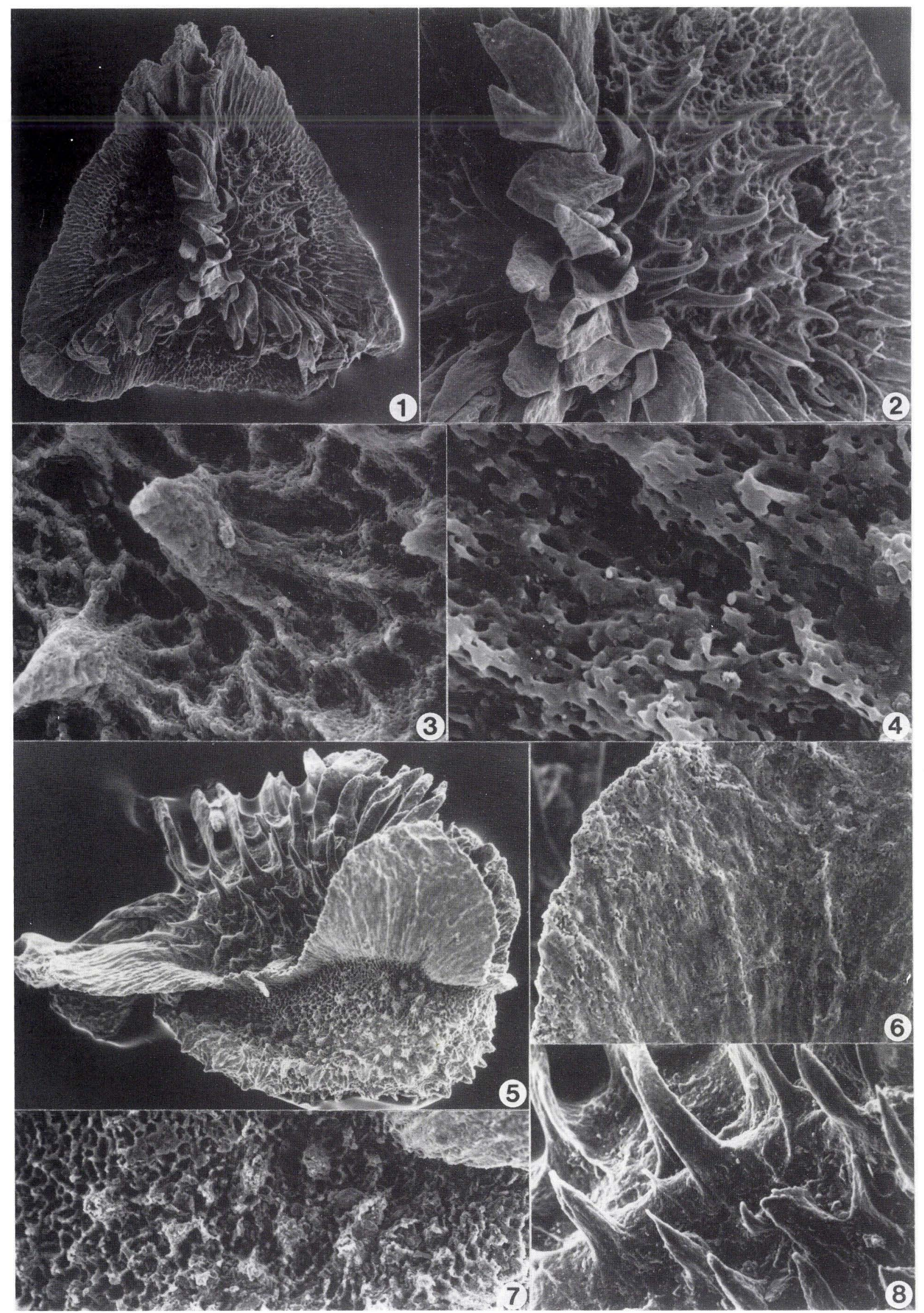


PLATE 19

Figs 1-3, Trileites candoris, broken specimen from Hasle Klinkerfabrik clay pit. 1, proximal view, $\times 100.2$, perforated outer surface of exoexine of contact area, $\times 3000.3$, transverse section of exoexine, $\times 3000$.

Fig. 4, Trileites murrayi from borehole 247.131, Eskegård, proximal view, $\times 270$.

Figs 5-8, Verrutriletes franconicus. 5, oblique-lateral view of spore from Sose Bugt outcrop, $\times 300$. 6, oblique view of another specimen from same locality, $\times 300.7$, close-up of wall adjacent to triradiate ridge, $\times 1000.8$, surface detail, $\times 5000$. 
Plate 19

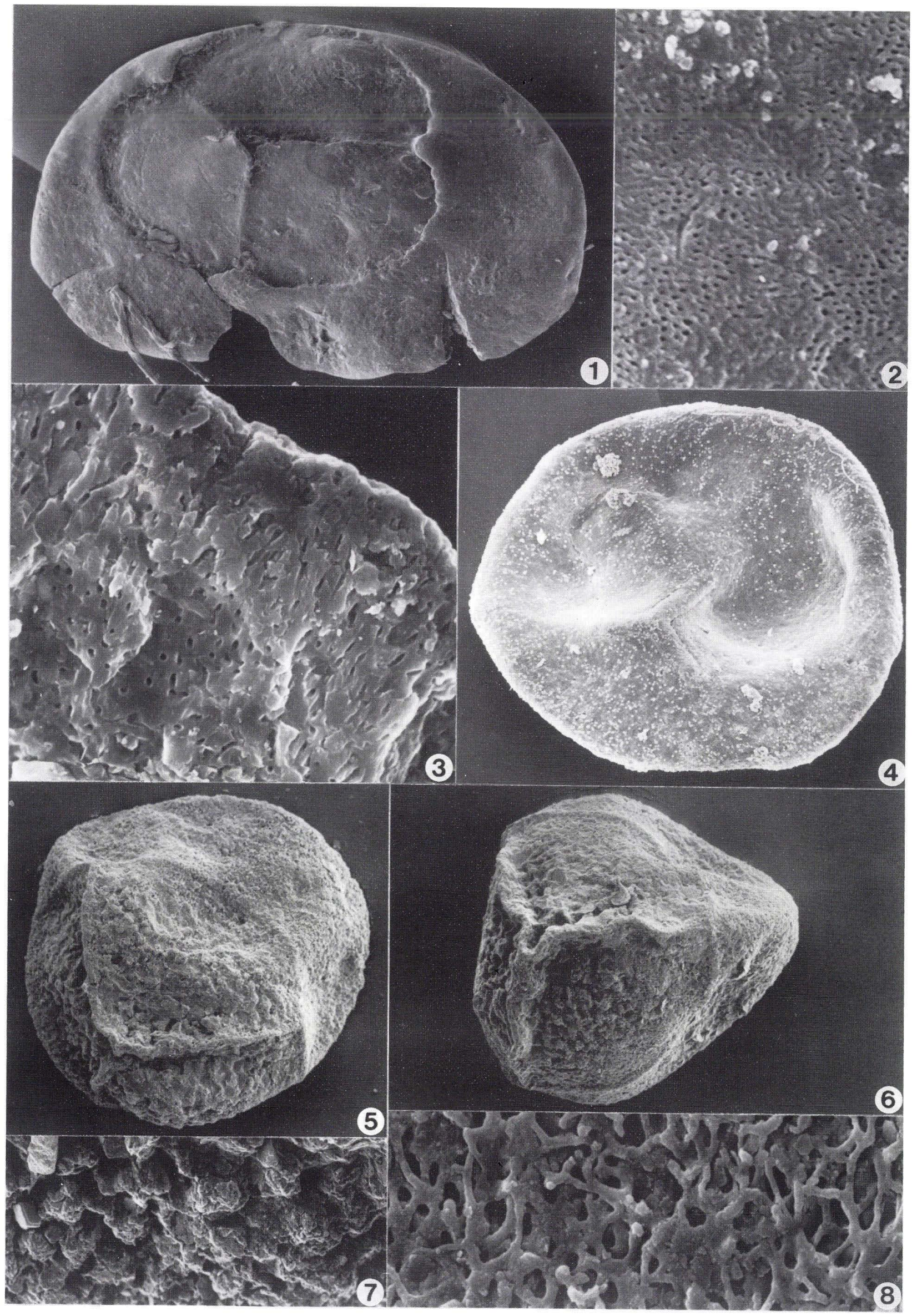


PLATE 20

Except where otherwise indicated, all magnifications $c . \times 75$. All specimens are stored in slides labelled according to name of taxon, plate and figure references below.

Fig. 1, Aneuletes patera

Fig. 2, Aneuletes discus, holotype, HGHol/1: for details, see systematics section

Fig. 3, Bacutriletes sp. cf. B. clavatus

Fig. 4, Bacutriletes corynactis

Figs 5, 6, Cabochonicus carbunculus

Fig. 7, Echitriletes hispidus

Fig. 8, Echitriletes lanatus

Figs 9, 10, Erlansonisporites sparassis

Figs 11,12 , Horstisporites areolatus, same specimen; 11, proximal face, 12 distal face; both $\times 50$

Fig. 13, Horstisporites harrisii

Figs 14-16, Horstisporites planatus; $14 \& 15, \times 100 ; 16, \times 250$

Fig. 17, Hughesisporites variabilis

Fig. 18, Hughesisporites galericulatus

Figs 19, 20, Henrisporites bornholmensis; 19 is holotype, HGHol/2: for details, see systematics section 
Plate 20

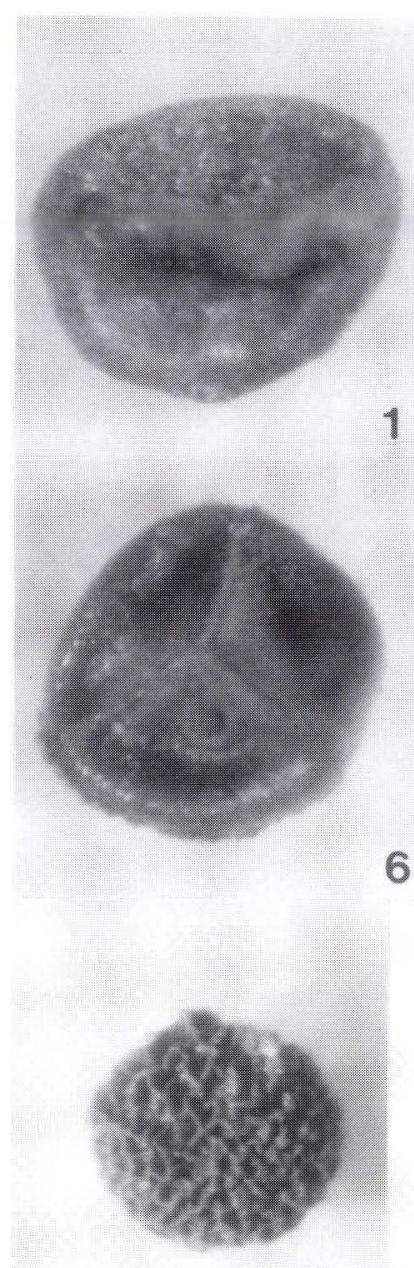

10

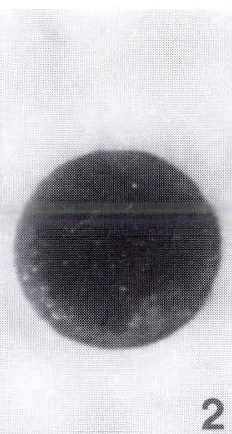

2

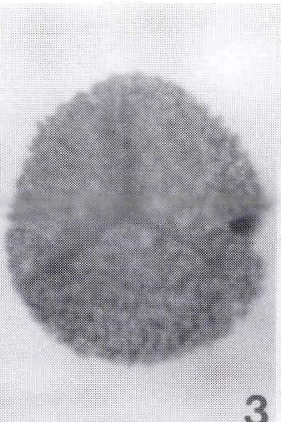

3

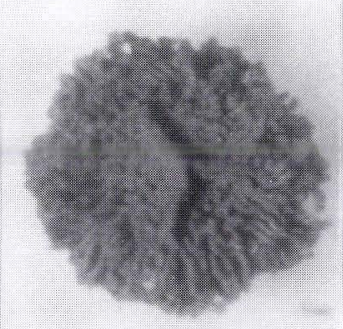

4

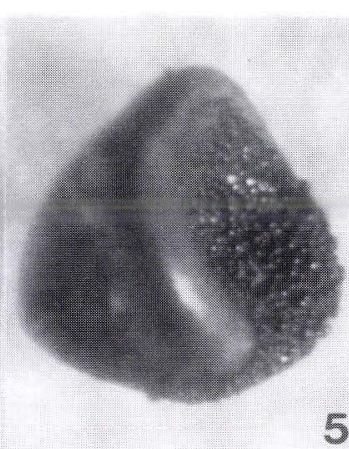

5
6
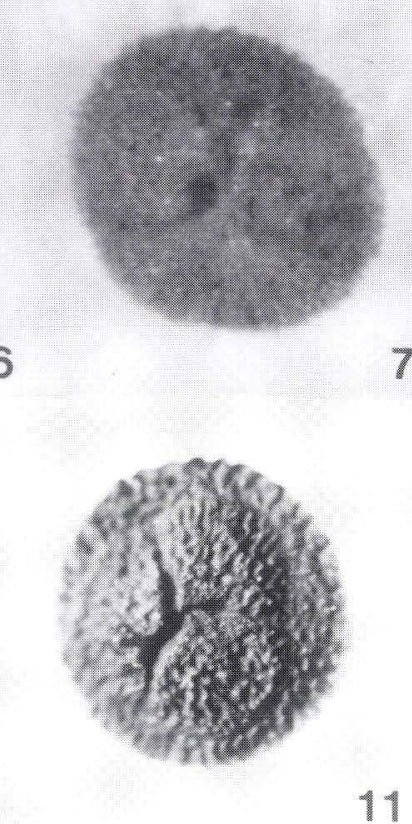

7

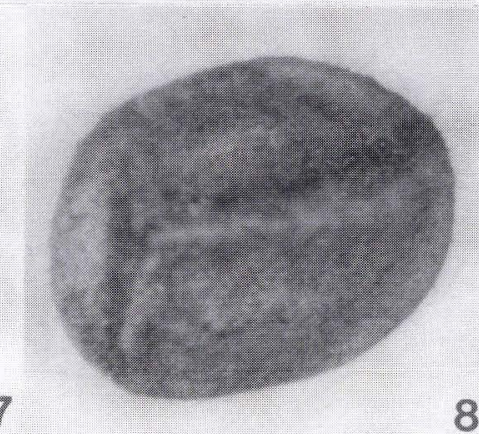

8

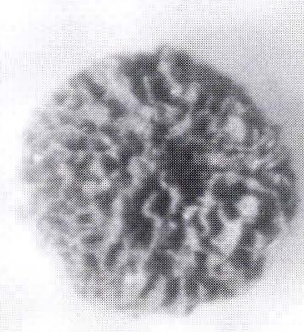

9

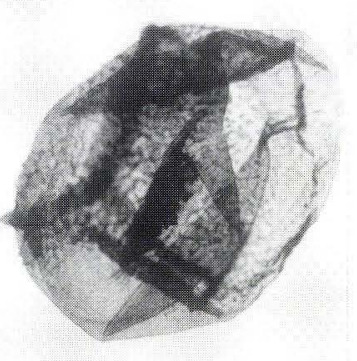

14

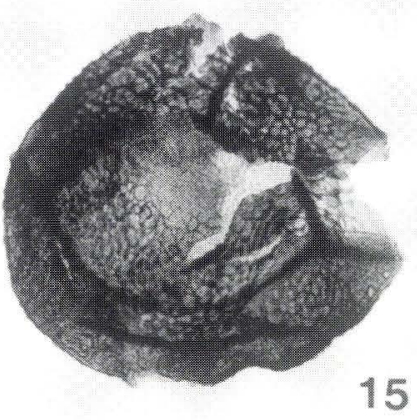

15

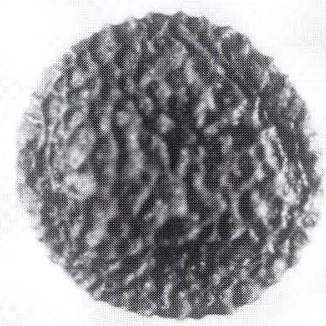

12

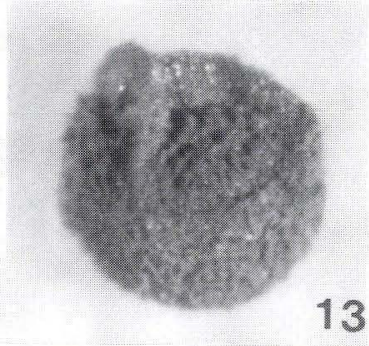

13
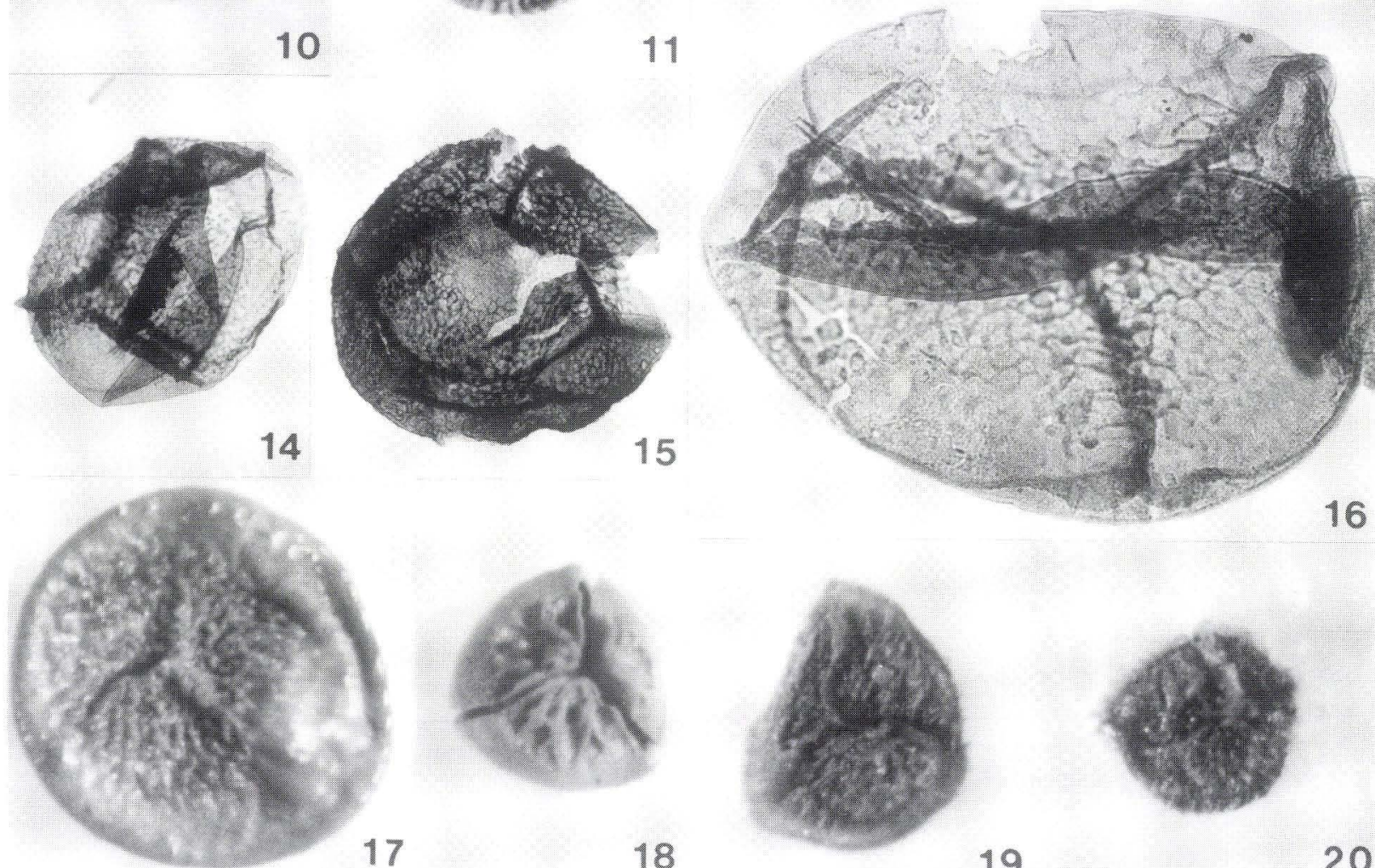

17

18

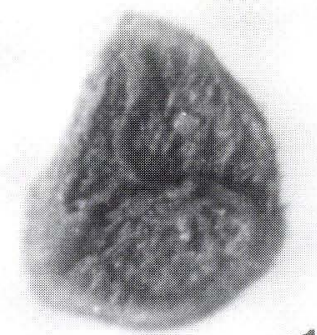

19

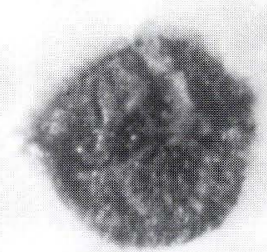

20 
PLATE 21

Except where indicated, all magnifications $c . \times 75$. All specimens are stored separately in slides labelled according to name of taxon, plate and figure references below.

Figs 1, 2, Maexisporites soldanellus

Figs 3, 4, Minerisporites marginatus

Fig. 5, Minerisporites richardsonii

Fig. 6, Minerisporites volucris

Fig. 7, Nathorstisporites hopliticus

Fig. 8, Paxillitriletes kristinae, holotype, HGHol/3: for details, see systematics section

Figs 9, 13, Paxillitriletes phyllicus

Figs 10, 11, Paxillitriletes sp. 3

Figs 12,18 , Paxillitriletes rasmusii; $12, c . \times 37.5 ; 18$ is holotype, $\mathrm{HGHol} / 4$ : for details see systematics section

Fig. 14, Paxillitriletes sp. cf. P. reticulatus

Fig. 15, Three specimens of Trileites candoris, c. $\times 37.5$

Fig. 16, Striatriletes sulcatus

Fig. 17, Verrutriletes franconicus

Fig. 19, Five specimens of Trileites murrayi, $\times 37.5$ 
Plate 21

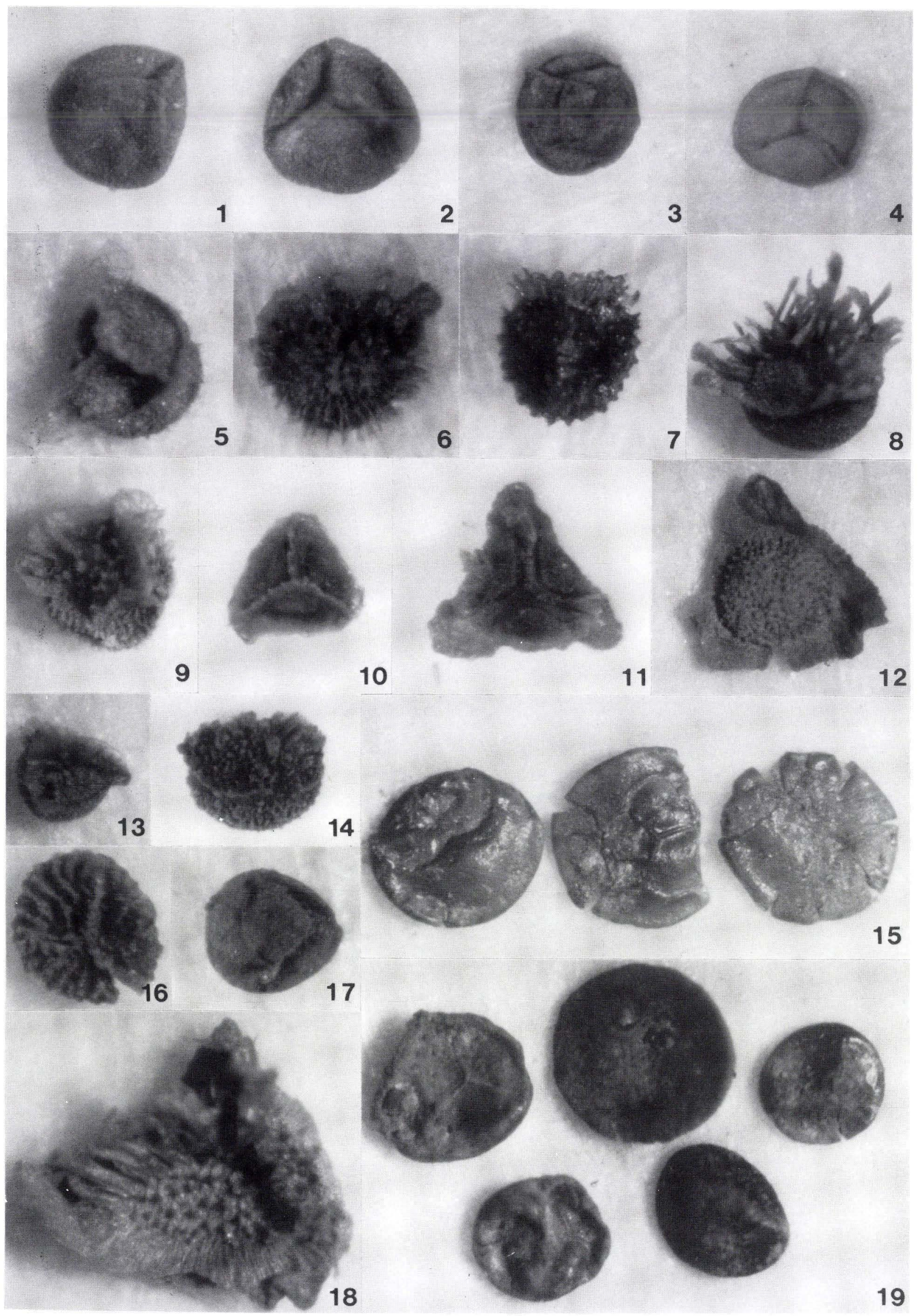


This paper presents a detailed systematic treatment of megaspores in Helge Gry's plant microfossil collection from the Jurassic and lowermost Cretaceous of Bornholm, Denmark. Thirty-seven taxa, four of which are new, are described and illustrated. Their botanical affinities and biostratigraphic potential are discussed. 